\title{
How SARS-CoV-2 and Other Viruses Build an Invasion Route to Hijack the Host Nucleocytoplasmic Trafficking System
}

\author{
Elma Sakinatus Sajidah ${ }^{1}$, Keesiang Lim ${ }^{2, *}$ and Richard W. Wong ${ }^{1,2,3, *}$ \\ 1 Division of Nano Life Science in the Graduate School of Frontier Science Initiative, Kanazawa University, \\ Kanazawa 920-1192, Japan; elmasajidah@stu.kanazawa-u.ac.jp \\ 2 WPI-Nano Life Science Institute, Kanazawa University, Kanazawa 920-1192, Japan \\ 3 Cell-Bionomics Research Unit, Institute for Frontier Science Initiative, Kanazawa University, \\ Kanazawa 920-1192, Japan \\ * Correspondence: limkeesiang@staff.kanazawa-u.ac.jp (K.L.); rwong@staff.kanazawa-u.ac.jp (R.W.W.)
}

check for updates

Citation: Sajidah, E.S.; Lim, K.; Wong, R.W. How SARS-CoV-2 and Other Viruses Build an Invasion Route to Hijack the Host Nucleocytoplasmic Trafficking System. Cells 2021, 10, 1424. https:/ / doi.org/10.3390/cells10061424

Academic Editor: Peter Askjaer

Received: 11 April 2021

Accepted: 3 June 2021

Published: 7 June 2021

Publisher's Note: MDPI stays neutral with regard to jurisdictional claims in published maps and institutional affiliations.

Copyright: (c) 2021 by the authors. Licensee MDPI, Basel, Switzerland. This article is an open access article distributed under the terms and conditions of the Creative Commons Attribution (CC BY) license (https:// creativecommons.org/licenses/by/ $4.0 /)$.

\begin{abstract}
The host nucleocytoplasmic trafficking system is often hijacked by viruses to accomplish their replication and to suppress the host immune response. Viruses encode many factors that interact with the host nuclear transport receptors (NTRs) and the nucleoporins of the nuclear pore complex (NPC) to access the host nucleus. In this review, we discuss the viral factors and the host factors involved in the nuclear import and export of viral components. As nucleocytoplasmic shuttling is vital for the replication of many viruses, we also review several drugs that target the host nuclear transport machinery and discuss their feasibility for use in antiviral treatment.
\end{abstract}

Keywords: viral nuclear import; viral nuclear export; nucleoporins; importins; exportin; SARS-CoV-2; Ebola virus; Dengue virus; Human Immunodeficiency virus; Influenza A; Human Papillomavirus; Hepatitis B virus; Epstein-Barr virus; antiviral drug; nuclear transport inhibitor; clinical trial; HS-AFM

\section{Introduction}

Despite advancements in science and technology, humans are still plagued by communicable diseases, and the development and production of effective antiviral drugs and vaccines remains challenging. Pathogenic viruses, one major category of infectious agents, have caused not only substantial morbidity and mortality, but also devastating socioeconomic impacts. Within the past century, there have been two particularly severe pandemics, as follows: the 1918 influenza pandemic and the currently ongoing coronavirus disease 2019 (COVID-19) pandemic.

As part of their lifecycle, many viruses hijack the host transcription and translation machinery while evading the host immune responses [1]. The host nucleoplasm and cytoplasm are segregated by a nuclear envelope (NE), a lipid bilayer embedded with numerous nano-gates known as nuclear pore complexes (NPCs) (reviewed in [2]). Nuclear transport is important for mediating numerous cellular activities, such as cell division [3,4], cell metabolism [5,6], gene regulation (review in [7]), and innate immune response activation [8]. As exploitation of the host nuclear transport is important for viral replication, the mechanisms that are used by viruses to hijack the host nuclear trafficking are potential targets for antiviral drugs; such drugs might halt viral genome transcription, viral protein synthesis, and viral assembly. In this review, we focus on the various mechanisms used by viruses, including severe acute respiratory syndrome coronavirus 2 (SARS-CoV-2), to hijack the host nucleocytoplasmic trafficking machinery. We describe various viral factors, and their target host factors, including importins and nucleoporins (Nups). Finally, we discuss the feasibility of using drugs that target the host nuclear transport machinery as antiviral therapies. 


\section{Fundamentals of Nucleocytoplasmic Trafficking}

NPCs are mega-Dalton-sized protein complexes that consist of about thirty different types of Nup. Cryo-electron microscopy and tomography observations indicate that NPCs are formed by an eight-fold symmetric central scaffold, eight cytoplasmic filaments, and eight nucleoplasmic filaments (nuclear basket), with the pores presenting rotational symmetry [9-11]. Phenylalanine-glycine (FG) repeats are found in many Nups, and the dynamic hydrophobic interactions among the FG-repeats of Nups in the central scaffold create a cohesive meshwork that can make the NPC become a selective channel $[12,13]$. Several models to describe the FG-containing Nup interactions, including the hydrogel model [14], virtual gating or polymer brush model [13], reduction in dimensionality model (reviewed in [15]), and forest model [16], have been put forward. Recently, we successfully observed the dynamic behavior of Nup FGs by using high-speed atomic force microscopy (HS-AFM) and proposed a new model of FG-containing Nup interactions called the coweb FG-network model [17]. The functional NPC pore diameter was initially reported as being approximately $26 \mathrm{~nm}$ [18], but the value was later corrected to approximately $40 \mathrm{~nm}$ [19]. Small molecules $(<40-60 \mathrm{kDa})$ pass freely through NPCs via passive diffusion. Conversely, large molecules, such as proteins, require receptor-mediated nuclear transport to move against a concentration gradient [19].

Receptor-mediated nuclear transport involves cargo proteins, nuclear transport receptors (NTRs), and the guanosine triphosphate-binding nuclear protein Ran (RanGTP) [2]. The types of NTRs required for transport differ depending on the traffic directionality. For nuclear import, selective cargo is recognized by specific NTRs via its nuclear localization signal (NLS) sites [2]. According to reviews authored by Pumroy et al. [20] and Mosammaparast et al. [21], several nuclear import pathways are available, depending on the cargo type. The best understood import pathway is the classical import pathway. It utilizes the heterodimeric importin- $\alpha / \beta 1$ transport receptor, in which importin- $\alpha$ works as an adaptor protein, bringing its cargo in concert with importin- $\beta$ to translocate it into the nucleus. There are seven importin- $\alpha$ isoforms expressed in humans, and they can be grouped into the following three subfamilies: $\alpha 1, \alpha 2$, and $\alpha 3$ (see Table 1). The conserved $\mathrm{N}$-terminal autoinhibitory importin- $\beta$-binding (IBB) domain and the C-terminal Armadillo (Arm) repeats (the NLS-binding sites) of $\alpha$-importins are important for the nuclear import of the NLS-bearing cargo [22-24].

Most of the identified NLS motifs consist of basic amino acids, such as lysine and arginine, and they are collectively named the classical NLSs (cNLSs). These NLSs are divided into the following two groups: monopartite cNLSs, which have a single stretch of amino acids (e.g., the NLS of the SV40 large T antigen), [25] and bipartite cNLSs, which have two stretches of amino acids separated by a linker region (e.g., the NLS of nucleoplasmin) [26]. There are many cargoes whose NLSs are still unknown. First, the cNLS-bearing cargo binds to the Arm repeats of importin- $\alpha$ [24], and then importin- $\beta$ binds to the IBB domain of importin- $\alpha$ [27] to form a ternary complex. The IBB domain can be considered as an NLS for $\alpha$-importins (i.e., a ubiquitous adaptor protein) as well as for other adaptor proteins that carry specific cargo (see Table 1). Once a ternary complex is formed by the cNLS-bearing cargo, importin- $\alpha$, and importin- $\beta 1$, the complex docks onto an NPC; subsequently, importin- $\beta 1-N u p$ FG interactions translocate the complex into the nucleus [28].

RanGTP is predominant in the nucleus, whereas the guanosine diphosphate-binding Ran (RanGDP) is abundant in the cytoplasm (reviewed in [29]). This RanGTP/RanGDP gradient is important for the dissociation of the cNLS-bearing cargo-importin- $\alpha / \beta 1$ ternary complex and the shuttling of importins back to the cytoplasm for the next functional cycle. RanGTP has a high affinity for importin- $\beta 1$ [30], and the binding of RanGTP to importin- $\beta 1$ dissociates the ternary complex, thus releasing the cargo in the nucleus [31-33]. The RanGTPimportin- $\beta 1$ complex is then exported to the cytoplasmic site of an NPC. Similarly, the nuclear export of importin- $\alpha$ also requires RanGTP along with a soluble transport factor known as the CAS (Cellular Apoptosis Susceptibility gene) protein or exportin-2 (XPO2) [34]. The hydrolysis of RanGTP to RanGDP is mediated by the RanGTPase- 
activating protein (RanGAP1) [35,36] and the RanGTP-binding protein (RanBP1) $[37,38]$ at the cytoplasmic site of an NPC, which helps to release importin- $\alpha$ and $-\beta 1$ back to the cytoplasm. RanGDP is then reimported to the nucleus by nuclear transcription factor 2 (NTF2) [39]. RCC1, the major nucleotide exchange factor of Ran, converts RanGDP back to RanGTP [40].

The nuclear export of cargo requires NTRs (exportins) that read the nuclear export signals (NESs) within cargo [22,24,41]. Chromosomal region maintenance 1 (Crm1), more commonly known as exportin 1 (XPO1), is the major export receptor for roughly 1000 different leucine-rich-NESs-containing cargoes in human cells [26,42]. For a list of other exportins, please refer to Table 1. A Crm1-mediated nuclear export starts with the formation of a Ran-binding protein 3 (RanBP3)-Crm1-RanGTP-NES-bearing cargo export complex. RanBP3 binds to Crm1 via its FG domains [43]. RanBP3 increases the affinity of the RanBP3-Crm1 complex for RanGTP and the NES-bearing cargo [43]. The quaternary export complex translocates through the NPCs by interacting with Nups and then docks at its terminal docking site, the cytoplasmic Nup214-Nup88 complex [44]. In most cases, RanGAP1 is not soluble but tethered to the NPCs via RanBP2. Cytoplasmic RanBP1 and RanGAP1 mediate RanGTP hydrolysis to disassemble the export complex [45]. A study reported that Crm1 interacts with NPCs in a Nup358/RanBP2-dependent manner [46]. In addition, in vitro experiments have shown that the isolated Ran-binding domain of Nup358 also induces the dissociation of Crm1-export complexes [47]. Collectively, these studies indicate that Crm1-export complexes dissociate after their interaction with soluble RanBP1 and/or Nup358, together with soluble and/or Nup358-associated RanGAP. Free Crm1 then interacts transiently with Nup358 to re-shuttle back to the nucleus [44].

Similar to cargo export, RNA export also requires specific receptors, which depend on the RNA type, in concert with adaptor proteins. These export receptors include the following: Nxf1 or TAP, the main mRNA export receptor [48]; Crm1, for ribosomal (r)RNA [49], small nuclear (sn)RNA [50], and some subsets of messenger (m)RNA [51]; Xpot, for transfer (t)RNA [52,53]; and exportin 5 (XPO5), for micro (mi)RNAs [54]. Several pathways mediate mRNA export, and the Nxf1-dependent pathway is the dominant pathway for exporting bulk mRNAs [55-57]. In an Nxf1-dependent mRNA export, mature mRNAs are packaged into messenger ribonucleoprotein particles (mRNPs) that then recruit mRNA export factors (e.g., an Nxf1-Nxt1 heterodimer) [58,59]. The interaction between an Nxf1-Nxt1 heterodimer, Rae1, and Nup98 enables mRNA to be delivered to the cytoplasm [60]. Nxf1 has two binding sites for Nxt1 (amino acid [aa] residues 372-445 [61] and 508-583 [60]) and Rae1 (aa residues 1-60 and 372-445) [60]. Only one Nxf1 binding site is necessary for Nxt1 binding (aa residues 372-445) [61], whereas the Nxf1-Rae1 interaction requires both binding sites [60]. The Nup98-binding site of Nxf1, which is located at the C-terminus of Nxf1 (aa residues 601-619), has the highest affinity for the GLFG-repeat domain of Nup98 [60]. Nup98 binds stably with Rae1, and the Rae1 that is pre-bound to Nup98 will not bind to Nxf1 [60]. Therefore, Nup98 provides a bridging site through which Nxf1 can bind to the adjacent site of Rae1 when both simultaneously interact with Nup98 [60]. This mechanism accomplishes mRNA export in a RanGTP-independent manner. Although Nxf1 has an RNA-binding domain at its C-terminus that can directly bind to the constitutive transport element (CTE) RNA of simian type D retroviruses [62], the Nxf1-Nxt1 heterodimer most frequently requires dedicated export adaptors, including Aly/REF and UAP56 (review in [63]). Likewise, Crm1 does not bind directly to mRNA; instead, it creates complexes with different types of mRNA-binding adaptor proteins, such as HuR [64], Nxf3 [65], and LRPPRC [66], to accomplish mRNA export in a RanGTP-dependent manner. In addition to interacting with mRNA, Crm1 also interacts with the adaptor protein Nmd3 to export the 60S ribosomal subunit [67]. 
Table 1. List of the nuclear transport receptors (NTRs) involved in nucleocytoplasmic shuttling.

\begin{tabular}{|c|c|c|}
\hline $\begin{array}{c}\text { Adaptor Protein } \\
\text { Importin } \alpha \text { Subfamilies }\end{array}$ & $\begin{array}{c}\text { Protein Name } \\
\text { (Importin Nomenclature) }\end{array}$ & $\begin{array}{c}\text { Protein Name } \\
\text { (Karyopherin Nomenclature) }\end{array}$ \\
\hline$\alpha 1$ & $\begin{array}{l}\text { Importin } \alpha 1 \\
\text { Importin } \alpha 8\end{array}$ & $\begin{array}{l}\text { Karyopherin } \alpha 2 \\
\text { Karyopherin } \alpha 7\end{array}$ \\
\hline$\alpha 2$ & $\begin{array}{l}\text { Importin } \alpha 3 \\
\text { Importin } \alpha 4\end{array}$ & $\begin{array}{l}\text { Karyopherin } \alpha 4 \\
\text { Karyopherin } \alpha 3\end{array}$ \\
\hline$\alpha 3$ & $\begin{array}{l}\text { Importin } \alpha 5 \\
\text { Importin } \alpha 6 \\
\text { Importin } \alpha 7\end{array}$ & $\begin{array}{l}\text { Karyopherin } \alpha 1 \\
\text { Karyopherin } \alpha 5 \\
\text { Karyopherin } \alpha 6\end{array}$ \\
\hline Importin $\beta$ family members & \multicolumn{2}{|c|}{ Cargoes } \\
\hline $\begin{array}{c}\text { Importin } \beta 1 \\
\text { (Karyopherin } \beta 1)\end{array}$ & \multicolumn{2}{|c|}{$\begin{array}{c}\text { Importin } \alpha \text { isoforms-cNLS-bearing cargoes } \\
\text { Snurportin } 1 \\
\operatorname{RIP} \alpha(\text { RPA-interacting protein } \alpha) \\
\text { Importin } 7\end{array}$} \\
\hline $\begin{array}{l}\text { Importin } \beta 2 \\
\text { (Transportin-1) }\end{array}$ & \multicolumn{2}{|c|}{$\begin{array}{l}\text { Ribosomal proteins } \\
\text { TAP/Nxf1 } \\
\text { Histones }\end{array}$} \\
\hline Transportin-2 & \multicolumn{2}{|c|}{ HuR (ELAV-like protein 1) } \\
\hline Transportin-SR & \multicolumn{2}{|c|}{ SR proteins (abundant arginine/serine-rich proteins) } \\
\hline $\begin{array}{c}\text { Importin } 4 \\
\text { (IPO4, RanBP4) }\end{array}$ & \multicolumn{2}{|c|}{ Histones and ribosomal proteins } \\
\hline $\begin{array}{c}\text { Importin } 5 \\
\text { (IPO5, RanBP5) }\end{array}$ & \multicolumn{2}{|c|}{ Histones and ribosomal proteins } \\
\hline $\begin{array}{l}\text { Importin } 7 \\
\text { (IPO7, RanBP7) }\end{array}$ & \multicolumn{2}{|c|}{$\begin{array}{c}\text { HIV PIC } \\
\text { H1 histone } \\
\text { GR (Glucocorticoid receptor) } \\
\text { Ribosomal proteins }\end{array}$} \\
\hline $\begin{array}{c}\text { Importin } 8 \\
\text { (IPO8, RanBP8) }\end{array}$ & \multicolumn{2}{|c|}{ SRP19 (Signal recognition particle 19) } \\
\hline $\begin{array}{c}\text { Importin } 9 \\
\text { (IPO9, RanBP9) }\end{array}$ & \multicolumn{2}{|c|}{ Histones and ribosomal proteins } \\
\hline $\begin{array}{c}\text { Importin 11 } \\
\text { (IPO11, RanBP11) }\end{array}$ & \multicolumn{2}{|c|}{$\begin{array}{l}\text { UBE2E3 (Ub-conjugating enzyme) } \\
\text { rpL12 (60S ribosomal protein L12) }\end{array}$} \\
\hline $\begin{array}{l}\text { Crm1 } \\
\text { (XPO1) }\end{array}$ & \multicolumn{2}{|c|}{$\begin{array}{c}\text { Snurportin } \\
\text { HuR (ELAV-like protein 1) [62] } \\
\text { Nxf3 (Nuclear RNA export factor 3) [63] } \\
\text { LRPPRC (Leucine-rich PPR motif-containing protein) [64] } \\
\text { Nmd3 (60S ribosomal export protein) [65] }\end{array}$} \\
\hline $\begin{array}{c}\text { CAS } \\
(\mathrm{XPO} 2)\end{array}$ & \multicolumn{2}{|c|}{ Importin $\alpha$} \\
\hline $\begin{array}{l}\text { Exportin } 4 \\
\text { (XPO4) }\end{array}$ & \multicolumn{2}{|c|}{ eIF-5A (Eukaryotic translation initiation factor 5A-1) } \\
\hline $\begin{array}{l}\text { Exportin } 5 \\
\text { (XPO5) }\end{array}$ & \multicolumn{2}{|c|}{$\begin{array}{l}\text { ILF3 (Interleukin enhancer-binding factor 3) } \\
\text { eEF1A-1 (Elongation factor 1-alpha 1) } \\
\text { pre-miRNA, tRNA, minihelix RNA }\end{array}$} \\
\hline $\begin{array}{l}\text { Exportin } 6 \\
\text { (XPO6) }\end{array}$ & \multicolumn{2}{|c|}{$\begin{array}{l}\text { Profilin } \\
\text { Actin }\end{array}$} \\
\hline $\begin{array}{l}\text { Exportin-T } \\
\text { (XPOT) }\end{array}$ & \multicolumn{2}{|c|}{ tRNA } \\
\hline $\begin{array}{l}\text { Importin } 13 \\
\text { (IPO13, RanBP13), import }\end{array}$ & \multicolumn{2}{|c|}{$\begin{array}{l}\text { RBM8A (RNA-binding protein 8A) } \\
\text { UBCE9 (SUMO-conjugating enzyme UBC9) } \\
\text { Pax6 (Paired box protein Pax-6) }\end{array}$} \\
\hline $\begin{array}{c}\text { Importin 13 } \\
\text { (IPO13, RanBP13), export }\end{array}$ & \multicolumn{2}{|c|}{ eIF-4C (Eukaryotic translation initiation factor 1A, X-chromosomal) } \\
\hline RanBP6 & \multicolumn{2}{|c|}{ Unknown } \\
\hline RanBP16 & \multicolumn{2}{|c|}{ Unknown } \\
\hline RanBP17 & \multicolumn{2}{|c|}{ Unknown } \\
\hline
\end{tabular}

Importins $\alpha$ : adapted from a review by Pumroy et al. [20]. Importins $\beta$ : adapted from a review by Mosammaparast et al. [21] and other studies [64-67]. Yellow indicates nuclear import, orange indicates nuclear export, green indicates bidirectional shuttling, and blue indicates unknown cargo. Only human cargoes are mentioned here. 


\section{Mechanisms of the Host Nuclear Transport Machinery Hijacking by Viruses}

The dominant NTRs, including heterodimeric importin- $\alpha / \beta$, Crm1, and Nxf1, together with the Nups involved in nuclear transport (Nup358, Nup214, Nup98, and Rae1), are the common targets that viruses hijack for shuttling viral factors between the cytoplasm and the nucleus. The viral replication site determines the purpose of the host nuclear transport subversion by the virus. For example, viruses that replicate in the cytoplasm tend to hijack the host nuclear transport for suppressing the interferon (IFN)-inducing antiviral responses. Conversely, viruses that replicate in the nucleus and assemble their products in the cytoplasm generally exploit the host nuclear transport for much more complicated activities, such as the nuclear import of a viral genome and the nuclear export of a newly synthesized viral genomic RNA to the cytoplasm. Below, we discuss the hijacking mechanisms employed by viruses in various viral families, grouped according to their site of replication, that is, cytoplasm (the Coronaviridae, Filoviridae, Flaviviridae, and Togaviridae families) or nucleus (the Orthomyxoviridae, Retroviridae, Papillomaviridae, Hepadnaviridae, and Herpesviridae families). We summarize these interactions in Table 2 and illustrate them in Figure 1.

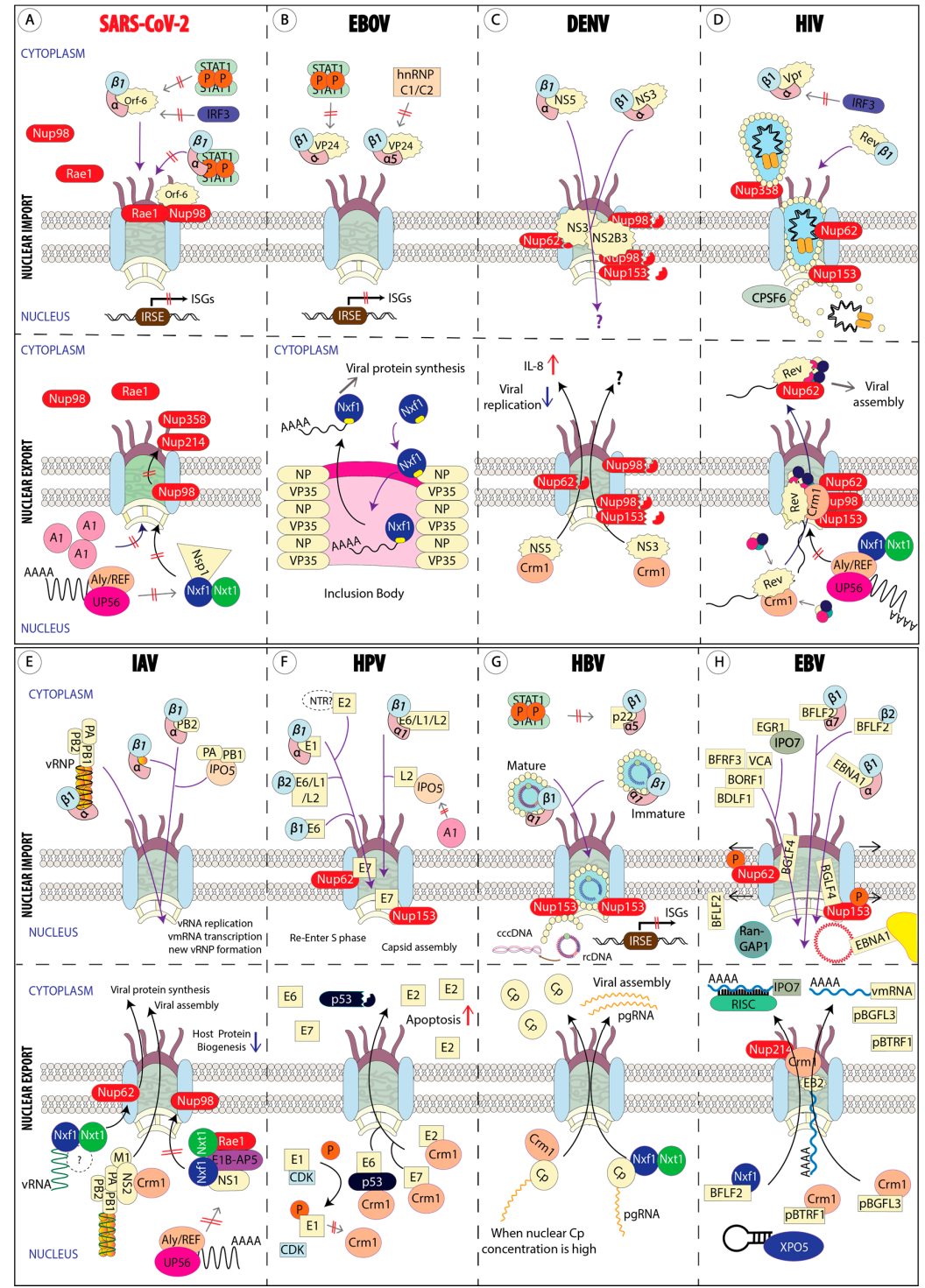

Figure 1. Interaction between viral factors and host factors to hijack host nuclear transport machinery. (A) SARS-CoV-2 
expresses Orf6 to suppress host antiviral response and Nsp1 to halt host protein biogenesis. (B) Ebola virus expresses VP24 to suppress host antiviral response. Ebola virus does not require nuclear export, but it needs the mRNA export factor, Nxf1, to mediate viral mRNA export from the inclusion body. (C) Dengue virus NS3 and NS2B3 degrade host Nups. The effect of the nucleocytoplasmic trafficking of both NS5 and NS3 in the host have yet to be elucidated. Nuclear export of Dengue NS5 is associated with elevated IL-8 production and reduced viral replication without a defined mechanism. (D) HIV capsids (yellowish balls) interact with host Nups (Nup358, Nup62, and Nup153) and CPSF6, then disassemble at an NPC basket to release PIC. HIV expresses Vpr to suppress host antiviral IFN production by blocking the nuclear translocation of activated IRF3. Nuclear import of HIV Rev is directly mediated by importin- $\beta 1$. Nuclear Rev protein is needed to form a viral ribonucleoprotein (vRNP) transport complex to export vRNP to the cytoplasm via a Crm1-mediated pathway. (E) The Influenza-A virus nucleoprotein (NP, yellowish balls) interacts with importin- $\alpha / \beta 1$ to enter the nucleus for viral replication. Newly synthesized NPs and RdRp components (PA-PB1 and PB2) hijack host importins to enter the nucleus for new vRNP formation. IAV NS2 facilitates the nuclear export of new vRNP, whereas IAV NS1 blocks host mRNA export by forming an inhibitory complex with Nxf1. (F) HPV high-risk E6 and E7 nuclear imports induce carcinogenesis by reprogramming the cell cycle to an S-phase and promote degradation of p53. In addition, HPV viral capsid proteins (L1 and L2) exploit host importins to translocate to the nucleus for capsid assembly. Nuclear export of E2 of high-risk HPV triggers cellular apoptosis. (G) Mature HBV capsid interacts with importin- $\alpha / \beta 1$ and Nup153 to uncoat the capsid in the nuclear basket. Immature HBV capsid remains in the NPC channel after it interacts with Nup153. HBV p22 blocks the nuclear translocation of p-STAT1 to suppress host antiviral response. HBV pgRNA export is mediated either by an Nxf1-Nxt1-dependent or a Crm1-dependent pathway, depending on the nuclear Cp concentration. (H) EBV EBNA1 translocates to the nucleus to tether EBV episomal DNA on host chromosome (yellow region). EBV BGLF4 disrupts the NPC structure and promotes nuclear accumulation of RanGAP1 to promote nuclear ingress of viral proteins (VCA, BFRF3, BDLF1, and BORF1) and inhibits host classical importin- $\alpha / \beta 1$ nuclear import. EBV tegument proteins (pBTRF1 and pBGLF3) bind with Crm1 to translocate to the cytoplasm for viral tegumentation. On the other hand, EBV miRNA is carried to the cytoplasm by host Exportin-5 (XPO5) to suppress importin-7 (IPO7) translation.

\subsection{Viruses That Replicate in the Cytoplasm}

\subsection{1. $\beta$-Coronaviruses (SARS-CoV-2, SARS-CoV-1, and MERS-CoV)}

Coronaviruses (CoVs; members of the Coronaviridae family) are enveloped, positivesense, single-stranded (+ss) RNA viruses. There are the following four genera in the Coronaviridae family: Alphacoronavirus $(\alpha-\mathrm{CoV})$, Betacoronavirus $(\beta-\mathrm{CoV})$, Gammacoronavirus $(\gamma-\mathrm{CoV})$, and Deltacoronavirus $(\delta-\mathrm{CoV})$ (reviewed in [68]). Although most human $\mathrm{CoVs}(\mathrm{HCoVs})$ are associated with mild upper respiratory diseases and enteric diseases (reviewed in [69]), the recently emerged zoonotic $\beta$-CoVs, such as severe respiratory acute syndrome $\mathrm{CoV}$ (SARS-CoV) and Middle East respiratory syndrome CoV (MERS-CoV), have caused severe lower respiratory diseases with high mortality (reviewed in [70]). Furthermore, a highly infectious novel $\beta-\mathrm{CoV}$, SARS-CoV-2, that was first reported in Wuhan, China in 2019 has caused the greatest pandemic in the 21st century [71]. All CoVs, including SARS-CoV-2, replicate in cytosolic double-membrane vesicles (DMVs) [72,73].

A protein-protein interaction (PPI) analysis of the viral factors and the host factors of SARS-CoV-2 revealed that the viral factors NSP9, NSP15, and Orf6 can interact with the host nuclear transport machinery [74]. The associations suggested by these PPI analyses need to be validated by further experiments. To date, only Orf6 has been shown to interrupt the host nucleocytoplasmic trafficking [75-78] and to induce an aberrant distribution of Nups (Nup98 and Rae1) [76]. Xia et al. found that Orf6 binds to importin- $\alpha 1$ to block the nuclear translocation of IRF3, resulting in an impaired type I IFN production in the HEK293T cell line [78]. Miorin and colleagues reported that type I and type II IFNs failed to induce the transcription of IFN-stimulated genes (ISGs) in SARS-CoV-2-infected Vero E6 cells owing to an impediment of the STAT1 and STAT2 nuclear translocation by Orf6 [75]. SARS-CoV-1 Orf6 plays a similar role in antagonizing IFN; it binds to importin- $\alpha 1$ and tethers importin- $\beta 1$ to the endoplasmic reticulum (ER)/Golgi membrane, sequestrating the NTRs from activated STAT1 (pY-STAT1) [79], thus blocking the nuclear translocation of a pY-STAT1 $[79,80]$. Miorin and colleagues proposed two mechanisms to explain this blockade. First, Orf6 binds to Nup98 via its C-terminal domain to interrupt the docking 
of cargo-importin- $\alpha 5 / \beta 1$ ternary complexes at the NPCs. The Orf6-Nup98 interaction does not affect the Nup98-Rae1 interaction, which suggests that Orf6 binding to Nup98 targets only the nuclear import pathway. Second, Orf6 competes with STAT1 and STAT2 for $\alpha$-importins ( $\alpha 5$ and $\alpha 1$ ) to block the STAT1/2 nuclear ingress. Nevertheless, these $\alpha$-importins may not be the direct key players because their overexpression failed to rescue an Orf6-dependent blockade of green fluorescent protein (GFP)-tagged STAT1 nuclear import. Interestingly, Addetia et al. reported that the SARS-CoV-2 Orf6 interactions with Nup98 and Rae1 were much stronger than those of SARS-CoV-1 Orf6, suggesting the strong IFN antagonism triggered by SARS-CoV-2 contributes to the high prevalence of asymptomatic cases of SARS-CoV-2 infection [77].

We found that, along with being able to impair nuclear import, SARS-CoV-2 Orf6 can also block nuclear export [76]. Our results show mislocalizations of Nup98 and Rae1 in Orf6-overexpressing cells [76]. In addition, nuclear accumulation of the nuclear RNAbinding protein hnRNPA1 was observed in Orf6-overexpressing cells. For mRNA export, hnRNPA1 is needed [81,82], and the saturation of hnRNPA1 in the nucleus inhibits mRNA export [81]. These findings, that is, the aberrant localization of Nup98 and Rae1 and the nuclear saturation of hnRNPA1, suggest that the Orf6-Nup98-Rae1 interaction can block mRNA export. Addetia et al. later found that SARS-CoV-2-infected cells exhibited a nuclear mRNA accumulation that could be mediated by Orf6 [77]. Recently, Zhang et al. reported that SARS-CoV-2 non-structural protein 1 (Nsp1) halted the host gene expression by blocking an Nxf1-Nxt1-mediated mRNA export [83]. Mechanistically, Nsp1 did not impair the RNA-binding ability of Nxf1; rather, it interrupted Nxf1 interacting with mRNA export adaptors, including Aly/REF and UAP56. Furthermore, Nsp1 reduced the interactions between Nxf1 and key Nups for nuclear export (Nup358, Nup214, and Nup98). SARS-CoV-1 Nsp1 was previously found to disrupt the localization of Nup93 (from the NE to the nucleoplasm) without affecting the NPC structure [84]. Furthermore, SARS-CoV-1 Nsp1 specifically promotes the cytoplasmic accumulation of the nuclear RNA-binding protein nucleolin with unknown consequences. These findings may indicate a role for SARS-CoV-1 Nsp1 in disrupting the host mRNA export [84].

SARS-CoV-1 Orf9b lacks an NLS and thus is localized mainly in the cytoplasm [85]. However, a small amount of Orf9b enters the nucleus passively, and nuclear Orf9b activates the host caspase-3-mediated apoptosis. As Orf9b degradation occurs in the cytoplasm, the nuclear export of Orf9b can protect the host and sustain viral replication [85]. Orf9b possesses an NES at aa residues 46-54 (LRLGSQLSL) that allows it to bind to Crm1 [85]. MERS-CoV Orf4b possesses an NLS (aa residues 2-38), and its nuclear localization is important for inhibiting IRF3- and IRF7-induced IFN- $\beta$ production [86]. Canton et al. later demonstrated that MERS-CoV Orf4b has a strong affinity for importin- $\alpha 3$, which blocks the NF- $\mathrm{B}$ p 65 subunit from entering the nucleus [87].

\subsubsection{Ebola Virus (Zaire Ebolavirus)}

Ebola virus (EBOV), a member of the Filoviridae family, is a filamentous, enveloped, single-stranded, negative-sense (-ss) RNA virus [88]. At present, there are six recognized EBOV species. The Zaire ebolavirus species has caused two outbreaks in Africa with 40 and $66 \%$ fatality, respectively, [89]. As EBOVs replicate in the cytoplasm, they hijack the host nuclear transport to suppress IFN-mediated antiviral responses. The EBOV VP24 protein interacts with importin- $\alpha 5,-\alpha 6$, and $-\alpha 7$ [90], but does not interact with importin$\alpha 1,-\alpha 3$, or $-\alpha 4$ [91]. A more recent study found that EBOV VP24 recognizes a non-classical NLS-binding site in importin- $\alpha 6$ [92]. These interactions allow EBOV to suppress the host IFN signaling by preventing the nuclear translocation of pY-STAT1 [91]. The VP24importin- $\alpha$ interaction also inhibits IFN- $\lambda$ production [93]. VP24 can directly bind to the inactive form of STAT1, unphosphorylated STAT1 (U-STAT1) [94]. The nuclear import of U-STAT1 is mediated by Nup153 and Nup214, independently of importins [95]. Within the nucleus, U-STAT1 activates and prolongs the expression of a set of IFN-induced genes that are distinct from those mediated by pY-STAT1 [96]. The VP24-importin- $\alpha 5$ interaction 
causes a cytoplasmic accumulation of the nuclear protein hnRNP C1/C2 [97]. During mitosis, hnRNP C1/C2 is exported to the cytoplasm for internal ribosomal entry site (IRES)dependent c-myc translation [98]. Several viruses similarly re-localize hnRNP C1/C2 to the cytoplasm, either for viral replication or IRES-dependent viral protein translation [99-102], which suggests that VP24-dependent hnRNP C1/C2 cytoplasmic accumulation is essential for EBOV replication [97]. Together, nucleoproteins (NPs) and VP35 form EBOV inclusion bodies (IBs) for viral replication [103]. A study conducted by Gabriel et al. showed that importin- $\alpha 7$ is also involved in IB formation [104]. In addition to creating new copies of EBOV genomic RNA, sub-genomic EBOV RNAs (viral mRNAs) are also produced for viral protein synthesis. The EBOV NP recruits Nxf1 by interacting with the RNA-binding domain of Nxf1. In the presence of mRNA, the binding preference of the Nxf1 RNAbinding domain shifts from NPs to mRNA, and then it delivers mRNA to the cytoplasm for translation [105].

\subsubsection{Dengue Virus (DENV) and Zika Virus (ZIKV)}

Flaviviruses (members of the Flaviviridae family) are small, enveloped +ssRNA viruses that replicate in vesicle packets located at the ER [106,107]. The flavivirus Dengue virus (DENV) causes mosquito-borne dengue fever in tropical and sub-tropical countries. Two nonstructural proteins (NSs), the DENV NS3 helicase and the DENV NS5 RNA-dependent RNA polymerase (RdRp), form a complex to mediate the viral replication [108,109]. NS5 promotes STAT2 degradation to suppress the host IFN-mediated antiviral responses [110]. An early study reported that NS5 has a bipartite NLS composed of an importin- $\beta 1$-binding site ( $\beta$ NLS) [111] and a heterodimeric importin- $\alpha / \beta 1$-binding site (cNLS) [112]. NS5 nuclear import is predominantly mediated by importin- $\alpha / \beta 1$ receptors [112]. However, later studies suggested that these mapped NLSs are not accessible to the host importins [113]. The subcellular localization of NS5 varies among the four DENV serotypes (DENV 1, 2, 3, and 4); the NS5 proteins of DENV2 and DENV3 reside in the nucleus, but the NS5 proteins of DENV1 and DENV4 are located in the cytoplasm [114,115]. A new monopartite NLS of NS5 has been identified at its C-terminus [115]. An in vitro assay revealed that the NS5 proteins of DENV2 and DENV3 have similar and strong affinities for importin- $\alpha 2$, whereas those of DENV1 and DENV4 have weak affinities for importin- $\alpha 2$ [115]. The NES in NS5 allows for Crm1-dependent NS5 nuclear egress, and this egression correlates with elevated IL-8 production and impaired viral replication, the mechanism of which has not yet been defined [116]. An NE abnormality together with deregulated NPC components were found in DENV-infected cells [117]. NS3 and its cofactor, NS2B3, disrupt the NPC integrity by inducing the proteolytic degradation of FG-Nups, including Nup62, Nup153, and Nup98 [117]. Palacios et al. reported that NS3 has a putative NLS and a putative NES. NS3 was localized within the nucleus during the early stages of infection, whereas it remained predominantly in the cytoplasm during the later stages of infection [118].

Another member of the Flaviviridae family, Zika virus (ZIKV), has posed serious health concerns owing to the rapid increase in cases of neonatal microcephaly linked to ZIKVinfected mothers in Brazil [119,120]. Similar to DENV, ZIKV also exploits the host NTRs and Nups during infection via its NS3 helicase and NS5 RdRp. A study conducted by De JesúsGonzález et al. showed that ZIKV NS3, in concert with NS2B3, promotes the proteolytic degradation of several FG-containing Nups, including TPR, Nup153, and Nup98, and also disrupts the NE structure [117]. ZIKV NS5, similar to DENV NS5, has a bipartite NLS (a $\beta$ NLS and a cNLS), which is recognized by importin- $\alpha 7$ [121]. The nuclear import of ZIKV NS5 protects it from cytoplasmic degradation, and this strategy helps to sustain viral replication in the host cells [122]. The cNLS was initially thought to be the primary site of NTR binding [123], but a later study revealed that both the $\beta$ NLS and the cNLS are required for NS5 nuclear import [122]. Nuclear NS5 sequesters various $\alpha$-importins $(\alpha 1$, $\alpha 3$, and $\alpha 4$ ) in nuclear bodies [123]. Intriguingly, the NS5 accumulated in nuclear bodies was incorporated with STAT1 in a glioblastoma cell line (LN229) but not in a hepatocellular carcinoma cell line (Huh-7), suggesting a role for NS5 in the tissue-specific activation of 
inflammatory responses [123]. Unlike the NS5 protein in Japanese encephalitis virus (JEV), which competes with the host IRF3 and NF-kB for $\alpha$-importins $(\alpha 1, \alpha 3$, and $\alpha 4)$ [124], ZIKV NS5 inhibits the activation of TANK-binding kinase 1 to prevent IRF3 activation [125], a strategy used to inhibit the IFN production by infected cells. Furthermore, ZIKV NS2A promotes the chaperone-mediated autophagy (CMA) of importin- $\alpha 1$ [126], possibly in an effort to suppress the host antiviral response.

\subsubsection{Chikungunya Virus (CHIKV)}

Chikungunya virus (CHIKV), a member of the Togaviridae family, is an enveloped +ssRNA virus that replicates in the host cytoplasm [127]. A CHIKV infection is associated with chronic inflammatory arthritis and other musculoskeletal diseases [128]. The CHIKV capsid protein (CP) has been reported to have two NESs and one NLS [129,130]. Thomas and colleagues demonstrated that the $\mathrm{CP}$ bound specifically to the C-terminal NLS-binding site of importin- $\alpha 3$ for its nuclear translocation [129]. The CP binds to Crm1 via its Crm1mediated NES, which was mapped to a leucine-rich region between aa residues 143 and 155 [129]. Thus, importin- $\alpha 3$ and Crm 1 are the host factors targeted by CHIKV in its disruption of the host nucleocytoplasmic trafficking [129]. A mutation of the CHIKV CP's NES near the N-terminus (aa residues 44-53) caused the retention of viral CPs in the nucleus and also blocked the host nuclear import system for unknown reasons [130]. CHIKV nsP2 inhibits the host IFN-induced antiviral response [131-134]. Although nsP2 lacks an NLS (reviewed in [135]), the nuclear import of nsP2 is necessary for suppressing the host antiviral response [134]. Interestingly, similar to that of DENV NS3, the nuclear localization of CHIKV nsP2 also occurs temporarily during early infection, after which this protein resides in the cytoplasm [136]. IFN antagonism by nsP2 can be achieved by several mechanisms, including via a reduction in the cGAS level by a global translational inhibition [131,136], an inhibition of STAT1 activation and/or block of pY-STAT1 nuclear import [133], and a promotion of STAT1 nuclear export [132].

\subsection{Viruses That Replicate in the Nucleus}

\subsubsection{Human Immunodeficiency Virus (HIV)}

Human immunodeficiency virus (HIV), a member of the Retroviridae family, is an enveloped +ssRNA virus that was first recognized in 1981 as the causative agent of a new disease affecting T lymphocytes [137]. HIV-1 is more virulent and infectious compared to HIV-2; thus, HIV-1 is the leading cause of acquired immunodeficiency syndrome (AIDS) in the ongoing AIDS pandemic [138]. Upon viral entry, the viral replication complex undergoes reverse transcription followed by integration to form a pre-integration complex (PIC) before entering the nucleus (reviewed in [139]). Mutations in HIV proteins and the silencing of some NPCs can change the HIV integration pattern, which suggests that nuclear import is closely associated with the selection of a viral cDNA integration site for integration into the host genome (review in [140]).

The HIV-1 viral capsid was initially postulated to rapidly disassemble upon viral entry, releasing PICs into the cytosol, from which they subsequently translocate to the nucleus through NPCs [141]. A group of RNA interference (RNAi) screening studies have identified several Nups that are required for a HIV-1 infection, which include Nup98, Nup85, Nup133, Nup107, Nup160, Nup153, Nup214, Nup358, Nup155, Crm1, and the nuclear import receptor transportin 3 (TNPO3) [142-144]. In addition, a HIV-1 infection induces a downregulation in Nup50 and an upregulation in Nup62 for currently unknown reasons [145]. Some HIV-1 proteins, such as integrase (IN) [146], the viral protein $R$ (Vpr) [147], and the matrix protein (MA) [148], contain NLSs. Notably, the width of the broad end of the HIV-1 capsid is approximately $60 \mathrm{~nm}$ [149], whereas the NPC pore size has long been thought to be only approximately $40 \mathrm{~nm}$ wide [19]. Collectively, these findings suggested that capsid disassembly is a prerequisite for PIC nuclear import.

More recent findings showing that the HIV-1 capsid remained assembled for at least the reverse transcription process [150] and that capsid uncoating can occur in the nu- 
cleus [151-153] have challenged the model described above. With a combination of different imaging tools, including cryo-electron tomography (cryo-ET) and subtomogram averaging, Zila and colleagues have visualized the entry of a whole HIV-1 capsid into a host nucleus through an NPC [154]. The diameter of an NPC measured in intact human cells (i.e., in a transporting state) was in fact larger than the diameter of an NPC measured in an isolated nuclear envelope (i.e., in a constricted state). The diameter of an NPC in the transporting state is larger than the broad end of the HIV-1 capsid; therefore, it can accommodate the import of a HIV-1 capsid into the nucleus. The team proposed a three-step process for the nuclear import of a HIV-1 capsid, during which the intact capsid interacts with different Nups in each stage. First, the HIV-1 capsids travel along microtubules to dock onto NPCs and interact with the FG-repeats and cyclophilin (Cyp) domain of Nup358 at the NPC cytoplasmic sites. Second, the intact capsids move deep into the central channels of the NPCs, which contain high local concentrations of FG-containing Nups within the Nup62 complex. Last, the capsids bind to Nup153 and cleavage and polyadenylation specificity factor subunit 6 (CPSF6). The HIV capsid-Nup153-CPSF6 interaction triggers capsid disassembly, which releases PICs into the nucleoplasm.

HIV Vpr suppresses the host antiviral response by interacting with $\alpha$-importins (preferentially $\alpha 5$, but also, to a lesser extent, $\alpha 1$ and $\alpha 4$ ) to inhibit the IRF3 activation and to block the nuclear import of IRF3 and NfkB [155]. HIV Vpr has an N-terminal NLS and a C-terminal NLS [156]. Its C-terminal NLS was initially thought to be non-functional [156], but later studies have shown that it binds $\alpha$-importins and mediates nuclear import without importin- $\beta 1[157,158]$.

HIV-1 Rev has an arginine-rich NLS site in its N-terminal domain and a leucine-rich NES sequence in its C-terminal domain (reviewed in [159]). HIV-1 Rev enters the nucleus without binding RNA because only the RNA-free form of Rev can bind to importin- $\beta 1$ for nuclear import [160]. The Rev-importin- $\beta 1$ interaction is highly specific and can be blocked by importin- $\alpha 5$ [160]. The Rev NES is required for the nuclear export of unspliced viral RNA (vRNA). Rev binds to vRNA via the Rev response element (RRE) (reviewed in [161]). Rev contains an NES that allows it to bind to Crm1 and subsequently bring vRNA, in the form of a viral ribonucleoprotein (vRNP) transport complex, out into the cytoplasm in a RanGTP-dependent manner [162]. Several studies have suggested that Nup214, Nup153, Nup98, and Nup62 interact indirectly with vRNP through different Rev co-factors [163-165]. For example, the Rev-vRNP complex disturbs NPC integrity and causes a Nup62 cytoplasmic localization and subsequent encapsidation into a progeny virus [166]. A downregulation in Nup62 induced a vRNA nuclear accumulation, suggesting the importance of Nup62 in vRNA export [166]. The host Nxf1-dependent RNA export always involves active pre-mRNA splicing to prevent aberrant protein translation. Rev suppresses Nxf1-mediated vRNA export to secure a viral gene expression in the host [167]. McCauley et al. reported that an HIV-1 provirus used Crm1 and Rev to export its unspliced HIV for translation, which triggered chronic inflammation in patients with HIV who were receiving anti-retroviral therapy [168].

\subsubsection{Influenza A Virus (IAV)}

Influenza A virus (IAV), a member of the Orthomyxoviridae family, is an enveloped, segmented -ssRNA virus that causes an epidemic respiratory disease (reviewed in [169]). IAV genomic RNAs are packed together with a viral nucleoprotein (NP) and a heterotrimeric RNA-dependent RNA polymerase (RdRp) complex (composed of PA, PB1, and PB2) into a rod-like vRNP (reviewed in [169]). Upon viral entry, free vRNPs translocate to the nucleus for viral RNA transcription and replication. The IAV NP and three components of the RdRp complex possess at least one NLS [170]. An IAV NP has two NLSs, a non-classical NLS in the N-terminus [171] and a classical bipartite NLS in the middle [172], and these are sufficient for vRNP nuclear import [170]. A mutation of the bipartite cNLS of the NP did not block its nuclear import, which suggests that the non-classical NLS of the NP is the predominant site [173] for its interaction with importins $\alpha 5$ and $\alpha 7$ [169]. Therefore, the 
non-classical NLS of an NP is essential for IAV replication [173]. Donchet et al. reported the binding affinity of an NP to different $\alpha$-importins; an NP had the highest affinity for importin- $\alpha 7$ and the lowest affinity for importin- $\alpha 1$ [174].

IAV PB2 has a classical bipartite NLS [175], enabling its binding to the host $\alpha$-importins $(\alpha 1, \alpha 5$, and $\alpha 7)[176,177]$, preferentially importin- $\alpha 7$ [178]. Interestingly, both importins $\alpha 1$ and $\alpha 7$ act as positive regulators for PB2 polymerase activity, whereas importin- $\alpha 3$ acts as a negative regulator [177]. Highly pathogenic avian IAVs (HPAIVs) with human-like PB2 downregulate the expression of importin- $\alpha 3$, the main NTR for NF- $\kappa B$, to suppress the host antiviral response [179]. The importin- $\beta$ family member importin-5 (IPO5), also known as RanBP5, not only forms an import complex with PA and PB1 but also regulates the PA-PB1 complex for vRNA binding [180,181].

The Crm1-mediated nuclear export of newly synthesized IAV vRNPs is crucial for new viral synthesis. IAV vRNP, M1, and NES-bearing NS2 form a complex for vRNP export [182,183]. IAV NS1 exerts a negative regulatory effect on the host Nxf1-dependent mRNA export by downregulating Nup98 expression and forms an inhibitory complex with several of the host mRNA export factors (Nxf1, Nxt1, Rae1, and E1B-AP5) [184]. IAV NS1 binds at the FG-repeat binding site of Nxf1, where it interacts with the FG-domain of Nup98 during mRNA export [185]. In addition to disrupting the host mRNA export, IAV NS1 also interrupts the host mRNA processing, which it achieves by interacting with CPSF30 [186] and PABII [187]. Collectively, these activities suppress the host protein biogenesis, particularly the factors required for an effective antiviral response [185]. Interestingly, in severe cases of influenza, a reduction in the protectin D1 (PD1) level enables IAV vRNA to bind directly to Nxf1, which then interacts with Nup62 for nuclear export. This mechanism does not require other mRNA export factors (e.g., Nxt1 or Crm1) or FG-containing Nups (e.g., Nup98 or Nup214) [188].

\subsubsection{Human Papilloma Virus (HPV)}

Human papilloma virus (HPV), a member of the Papillomaviridae family, is a small, icosahedral, non-enveloped, double-stranded (ds)DNA virus [189]. In 1995, the International Agency for Research (IARC) classified HPV16 and HPV18 as human carcinogens because infection with these viruses increases the risk of developing cervical cancer [190]. HPV replicates in the host nucleus, and the entry of its viral genome into the host nucleus requires NE breakdown (during mitosis) rather than passage through an NPC [191,192].

The nucleocytoplasmic shuttling of E6 and E7, two oncoproteins found in high-risk HPVs, promotes carcinogenesis in HPV-infected cells. Only high-risk HPV E6 (E6 high $_{\text {) can }}$ translocate to the nucleus [193] because its C-terminal contains three NLSs [193-195] that interact with importin- $\alpha 1 / \beta 1$, importin- $\beta 1$, and importin- $\beta 2$ [194]. Low-risk HPV E6 (E6 $6_{\text {low }}$ ) predominantly resides in the cytoplasm, but E6 $6_{\text {low }}$ acquires nuclear import activity when it is conjugated with an E6 $6_{\text {high }}$ NLS [193]. The nuclear import of E6 ${ }_{\text {high }}$ requires RanGDP, but GTP hydrolysis is not necessary [194]. Nuclear E6 ${ }_{\text {high }}$ is critical for E6-mediated p53

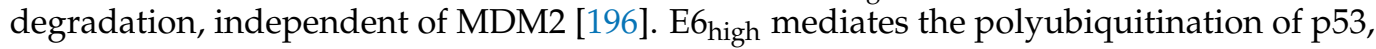
making it susceptible to proteosome degradation [197]. The E6 $6_{\text {high }}-\mathrm{p} 53$ interaction promotes p53 export, and the p53 NES is required for a Crm1-mediated nuclear export [197].

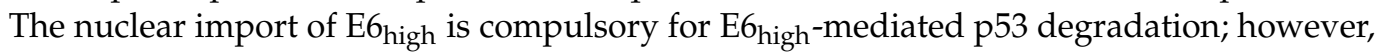
the p53 degradation can occur in both the nucleus and the cytoplasm [197].

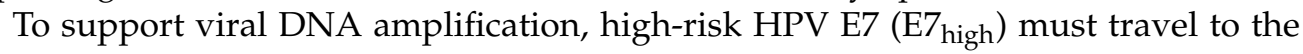
nucleus to hijack the host cell-cycle machinery, driving the host cell to re-enter the Sphase (reviewed in [198]). HPV16 E7 was initially thought to lack an NLS, and its nuclear import is Ran-dependent but independent of classical importin- $\alpha / \beta$ and importin- $\beta 2$ receptors [199]. Knapp et al. later identified two NLSs in the N-terminal domain and CR3 domain of the HPV16 E7 protein [200]. Eberhard et al. found an explanation for the ability of the HPV16 E7 protein to undergo importin-independent nuclear import, despite having NLSs [201]. The zinc-binding domain within the E7 CR3 domain contains a hydrophobic patch $\left.{ }_{65} \mathrm{LRLCV}_{69}\right)$ that enables $\mathrm{E7}$ to accomplish its nuclear import by interacting with the 
FG-domain of Nup62 via a hydrophobic interaction [201]. Furthermore, this hydrophobic patch also facilitates the interaction of HPV16 E7 with Nup153 [202]. The hydrophobic interaction between HPV E7 and FG-containing Nups is conserved in other HPV serotypes (HPV8 and HPV11) [202,203]. A functional NES has been identified in HPV16 E7, which suggests that E7 nuclear egress is Crm1-dependent [200].

HPV encodes the E1 DNA helicase and the E2 original recognition protein and uses them to hijack the host DNA replication machinery for viral replication [204]. Therefore, the nuclear localization of E1 and E2 are important for efficient viral replication. The E1 proteins of several HPV serotypes (HPV11, HPV31, and HPV16) have bipartite NLSs [205], and these NLSs behave in a similar way to the bipartite NLS of the bovine HPV E1 protein [206], which can interact with multiple importins $\alpha(\alpha 1, \alpha 3$, and $\alpha 5)$ [207]. In addition, the phosphorylation of HPV E1 by the host ERK and/or JNK is needed for its nuclear import $[205,206]$. Regarding the HPV E1 nuclear export, this protein has a functional NES site, suggesting it undergoes a Crm1-dependent export [204,208]. This NES has a cyclindependent kinase (CDK) phosphorylation site, and NES phosphorylation by CDK causes HPV E1 to be retained in the nucleus, which is essential for viral replication $[206,208]$.

The subcellular localizations of E2 proteins from low-risk (HPV11 and HPV6) and high-risk (HPV16 and HPV18) HPVs differ; low-risk HPV E2 is predominantly localized in the nucleus, whereas high-risk HPV E2 can be found in both the cytoplasm and the nucleus [209]. The NLS of the HPV11 E2 protein, but not those of the HPV16 and HPV18 E2 proteins, was found to have a dominant function [209]. Interestingly, cNLSs are found in high-risk HPV E2 but not in low-risk HPV E2; however, the NTRs for high-risk HPV E2 are still unknown [210]. The NES in high-risk HPV E2 enables the nucleocytoplasmic shuttling of this protein. Cytoplasmic accumulation of the high-risk HPV E2 proteins promotes caspase-8-mediated cell apoptosis [209].

The HPV L1 major capsid protein (L1) and L2 minor capsid protein (L2) are delivered to the nucleus for virion production. HPV16 L1 possesses both a monopartite and a bipartite NLS, and its nuclear import requires importin- $\alpha 1 / \beta 1$, RanGDP, and free GTP, but occurs independently of GTP hydrolysis [211]. The L1 protein also binds importin- $\beta 2$, but RanGTP is unable to dissociate the complex [211]. This interaction inhibits the importin$\beta 2$-mediated nuclear import of hnRNP A1 [211]. An L2 protein nuclear import is required for HPV viral assembly [212]. For nuclear import, the HPV16 L2 protein can interact with importin- $\beta 2$, importin- 5 , or the importin- $\alpha 1 /$ importin- $\beta 1$ heterodimer. An NES has been identified in the L2 protein, but its function remains unclear.

\subsubsection{Hepatitis B Virus (HBV)}

Hepatitis B virus (HBV), a member of the Hepadnaviridae family, is a small, enveloped dsDNA virus that propagates in hepatocytes [213]. Acute infection with HBV causes acute hepatitis, whereas chronic infection with HBV increases the risk of hepatocellular carcinoma (HCC) (reviewed in [214]). The HBV capsid disassembles in the nucleus, releasing relaxed circular DNA (rc)DNA, which is subsequently repaired by the host DNA repair machinery to form a covalently closed circular DNA, (ccc)DNA. The HBV cccDNA serves as a template for viral RNA replication (reviewed in [215]). Phosphorylation of the C-terminal HBV core or the capsid protein (Cp) exposes the Cp NLS, allowing the Cp to recruit classical importin$\alpha / \beta 1$ receptors to mediate the nuclear import of the HBV capsid [216,217]. In addition to phosphorylation, the completion of the (+) DNA and removal of viral DNA polymerase from rcDNA triggers a conformational change of the Cp, exposing the C-terminal NLS site [218]. During its translocation through an NPC, RanGTP triggers the dissociation of the $C p$-importin- $\alpha / \beta 1$ ternary complex, which allows for an interaction between the $C p$ and Nup153 [219]. Notably, Nup153 is the sole FG-containing Nup that interacts with the $\mathrm{Cp}$, which suggests that this interaction is not mediated by a hydrophobic interaction [219]. Finally, mature HBV capsids disintegrate in a Ran-independent manner [217], releasing viral rcDNA; capsid disassembly is halted in immature capsids [219]. 
The $\mathrm{Cp}$ has the following four arginine-rich domains (ARDs): ARD I and III each behave in a similar way to an NLS, and ARD II and IV each behave in a similar way to an NES [220]. The Cp NES is needed for an Nxf1-dependent viral pre-genomic RNA (pgRNA) export [220]. The nuclear export of pgRNA is a critical step for new virion synthesis. The subcellular localization of the $\mathrm{Cp}$ is rather complex, depending on both the intrinsic factors (NLS and NES) and the extrinsic factors (importins, Nxf1, and cellular kinase) [220]. A recent study showed that increasing the nuclear $\mathrm{Cp}$ concentration induces $\mathrm{Cp}$ export in a Crm1-dependent manner, which suggests that the Cp concentration may manipulate different export signals [221]. An empty Cp can interact with importin- $\beta 1$ independent of importin- $\alpha$ via its IBB domain, but the exact biological function of this interaction is yet to be elucidated [222]. Mitra and colleagues reported that the cytosolic HBV e antigen (HBeAg), also known as the precore protein intermediate (p22), interacts with importin- $\alpha 5$ through its C-terminal ARD. This interaction blocks the pY-STAT1 nuclear import and subsequently suppresses the host IFN response [223].

\subsubsection{Herpes Simplex Virus Type-1, Human Cytomegalovirus, and Epstein-Barr Virus}

Herpes simplex virus type- 1 (HSV-1) is a dsDNA $\alpha$-herpesvirus that causes cold sores in human beings [224]. After internalization, the viral capsid travels along microtubules to reach the nucleus to release a viral genome into the nucleoplasm for transcription and translation [225]. The tegument proteins VP1/2 [226] and pUL25 [225] interact with Nup358 and Nup214 to dock the viral capsid on an NPC. VP1/2 has an efficient NLS at its N-terminal, but the protein is mainly located in the cytoplasm [227]. The NLS of VP1/2 is specific to importin- $\beta 1$ rather than importins $\alpha[227,228]$, and VP1/2-importin- $\beta 1$ interaction is important for directing the viral capsid to dock on an NPC [227]. Using mouse embryonic fibroblast (MEF) cells, Döhner et al. comprehensively demonstrated the distinct importin- $\alpha$ isoforms $(\alpha 1, \alpha 3$ and $\alpha 4)$ in mediating HSV-1 gene expression, nuclear localization of viral proteins, capsid assembly, and capsid egress [229]. Importins are not needed for the NPC docking of an HSV-1 capsid, for the nuclear import of incoming HSV-1 genomes, or for the nuclear translocation of the HSV-1 VP16 protein. Importins $\alpha$ indirectly regulate the HSV-1 protein expression, and within this regulation importin- $\alpha 1$ is facilitative but importin- $\alpha 4$ is restrictive. Importin- $\alpha 1$ and Importin- $\alpha 3$ orchestrate the nuclear localization of immediateearly (ICP4 and ICP0) and early (ICP8 and pUL42) HSV-1 proteins. The HSV-1 DNA polymerase subunits pUL30 and pUL42 utilize several nuclear import mechanisms. HSV-1 pUL30 has a non-canonical and a classical bipartite NLS, and interacts with importin- $\alpha 5$, but interactions with other importin- $\alpha$ isoforms remain unknown [230-232]. HSV-1 pUL42 has a bipartite NLS, and the NLS binds mainly to importin- $\alpha 7$ and, to a lesser extent, to importin- $\alpha 1$, but not to importin- $\alpha 3$ [233]. Interestingly, the mutation of the NLS in either pUL30 or pUL42 does not impede the nuclear import of both proteins under the holoenzyme form [233]. The holoenzyme only resides in cytosol if the NLSs in both pUL30 and pUL42 are mutated [233]. Importin- $\alpha 1$ is crucial for an HSV-1 infection because importin$\alpha 1$ is required for efficient capsid assembly and egress to make new virions in cytosol. The team also illustrated that silencing either importin- $\alpha 1$ or importin- $\alpha 3$ is sufficient to suppress HSV-1 gene expression in terminally differentiated cells, neurons for example, but HSV-1 gene expression remains unperturbed in MEF cells [229]. MEF is not a terminally differentiated cell type [234]. Such a discrepancy indicates that importins $\alpha$ repertoire in MEF is sufficient to compensate for the absence of importin- $\alpha 1$ or importin- $\alpha 3$ to sustain HSV-1 gene expression.

HSV-1 ICP27 is an immediate-early protein that is required for enhancing HSV-1 gene expression and for exporting intronless HSV-1 mRNAs (review in $[235,236]$ ). Different conformations of ICP27 confer different specificities/preferences for nuclear export. Viral mRNA-bound ICP27 interacts with Aly/REF to recruit Nxf1 to export intronless HSV-1 mRNA for translation [237]. Nonetheless, Aly/REF knockdown does not significantly dampen viral mRNA export [238], suggesting that ICP27 could utilize other host export factors to compensate for Aly/REF. Free ICP27 does not require both Nxf1 and Crm1 for 
its export [239]. Instead, its $\mathrm{N}$ and $\mathrm{C}$ termini interact with Nup62 to enable ICP27 shuttles between the cytoplasm and the nucleus. The nuclear import of ICP27 inhibits both classical, importin- $\alpha / \beta 1$-dependent, and transportin-dependent nuclear import [240]. Beside the main export receptor (Nxf1), a recent finding reveals that the HSV-1 integral protein, glycoprotein M (gM), binds to exportin-6 (XPO6) for nuclear export to the trans-Golgi network (TGN) [241].

Human cytomegalovirus (HCMV) is a ds-DNA $\beta$-herpesvirus that is associated with mononucleosis syndrome (review in [242]), venous thromboembolism (VTE) (review in [242]), and cytomegalovirus encephalitis in immunocompromised patients (review in [243]). HCMV pUL97 is a multifunctional protein kinase that phosphorylates CDK1 and modifies the host G2/M cell cycle checkpoint regulators to promote viral replication [244]. There are two isoforms of pUL97, large and small isoforms. The large isoform has two bipartite NLSs (NLS1 and NLS2), whereas the small isoform only has NLS2, located at their N-terminals [245]. Therefore, the large isoform has a higher nuclear localization efficiency compared to the small isoform [245]. Only importin- $\alpha 1$ has been shown to interact with pUL97, and other importin- $\alpha$ isoforms have not been tested [245]. HCMV pUL79 is an elongation factor of RNA polymerase II for viral gene transcription during the late stages of HCMV infection [246]. HCMV pUL79 possesses a hydrophobic PY-NLS, which enables it to translocate to the nucleus through an importin- $\beta 2$-mediated pathway [247]. The multifunctional protein, HMCV pUL84, is believed to initiate lytic viral DNA synthesis [248]. Lischka et al. performed in vitro transport assays and found that the nuclear import of pUL84 relies on the classical importin-mediated import pathway [249]. Although pUL84 has a putative NLS, the NLS does not have the NLS activity [249]. Instead, a large domain with 282 amino acids is needed for an importin- $\alpha-$ pUL84 interaction [249]. A team has shown that pUL84 interacted with several importin- $\alpha$ isoforms, including $\alpha 1, \alpha 3, \alpha 4$, and $\alpha 5$ [249]. Interestingly, the pUL84-importin- $\alpha$ interaction domain also contains two leucin-rich NESs, and this region allows the nuclear export of pUL84 via the Crm1-dependent pathway [250]. Gao and his coworkers conducted RNA pulldown assays to reveal pUL84's viral mRNA export activity [248]. The team reported that pUL84 interacted with a viral-encoded transcript known as IRS1 and mediated the cytoplasmic localization of an IRS1 transcript [248].

Similar to HSV-1 ICP27, HCMV encodes the pUL69 regulatory protein to mediate a viral mRNA export. The arginine rich RNA-binding domain and the DExD/H-box helicase UAP56-binding motif in pUL69 [251] allows pUL69 to interact with the mRNA export factor UAP56/URH49 [252], transcription elongation factor hSPT6, and intronless viral mRNA to form a messenger ribonucleoprotein (mRNP) for an Nxf1-Nxt1-dependent mRNA export (reviewed in [253]). An NES is required for the nuclear export of free pUL69 but independent of Crm1, and the exact export mechanism remains elusive [254]. Likewise, in silico analysis failed to determine a classical NLS within pUL69, the NTRs associated with pUL69 nuclear import are also unknown [252]. CDK9 phosphorylation of pUL69 is crucial for a pUL69-mediated viral mRNA export because CDK inhibition triggers the nuclear accumulation of pUL69 and suppresses the mRNA export activity of pUL69 [255].

The Herpesviridae family member Epstein-Barr virus (EBV), also known as human herpesvirus 4 , is a dsDNA $\gamma$-herpesvirus that is associated with the development of three types of B-cell lymphoma (Burkitt's lymphoma, Hodgkin's lymphoma, and diffuse large B-cell lymphoma) and of nasopharyngeal carcinoma (NPC) (reviewed in [256]). Viral replication, which occurs in the host nucleus, has two different replication patterns, latent replication (during B-cell proliferation) and lytic replication (virion production) (reviewed in [256]). In latent replication, EBV nuclear antigen 1 (EBNA1) is the only viral protein needed in the host nucleus for viral DNA retention [257]. EBNA1 has an NLS (379KRPRSPSS386) that binds to importin- $\alpha 1$ and importin- $\alpha 5$ for its nuclear import [257]. In lytic replication, several viral proteins, including the DNA-replicating enzymes BSLF1, BBLF2/3, BBLF4, and a major capsid protein (VCA), are translocated to the nucleus for viral DNA replication and nucleocapsid assembly [258]. However, these viral proteins do not possess canonical NLSs. To circumvent this limitation, EBV expresses the BGLF4 protein 
kinase to facilitate nuclear translocation, probably by inducing the nuclear accumulation of RanGAP1 to inhibit the nuclear import of cNLS-bearing cargoes, phosphorylating FG-containing Nups (Nup62 and Nup153) to dilate the NPC, and inducing microtubule reorganization to change the nuclear shape [258]. The BGLF4 homolog proteins Herpes Simplex 1 (HSV-1) UL13 ( $\alpha$-herpesvirus), human Cytomegalovirus (HCMV) UL97 ( $\beta$ herpesvirus), Kaposi's sarcoma-associated herpesvirus (KSHV) ORF36 ( $\gamma$-herpesvirus), and Murine Gammaherpesvirus 68 (MHV68) ORF36 ( $\gamma$-herpesvirus) promote nuclear lamina disassembly via a BGL4-like mechanism [259,260]. Intriguingly, only $\gamma$-herpesvirus BGL4 homolog proteins (KSHV ORF36 and MHV68 ORF36) can mediate the nuclear import of VCA [258].

The nuclear translocation of EBV EGR1 is mediated by importin-7 (IPO7) [261], and the accumulation of EGR1 is correlated with the viral lytic phase [262]. EGR1 can negatively regulate IPO7 expression using EBV miRNAs (mirBART3 and mirBART16) to maintain a level that is optimal for the growth of EBV-transformed cells [261]. EBV EB2 (also called $\mathrm{M}$ or SM) interacts with Crm1 to boost the EB2-mediated gene expression and also to mediate the export of unspliced lytic EBV mRNA [229]. EB2 was shown to be associated with the GTPase Ran and Nup214 during the export of EBV mRNA to the cytoplasm [263]. Herpesviridae family members express nuclear egress proteins 1 (BFLF1) and 2 (BFRF2) to form a nuclear egress complex (NEC) at the host inner NE, which allows the export of new viral capsids containing viral DNA [264-266]. EBV BFLF2 interacts with EBV BFRF1 and lamin B at the nuclear rim, making a nuclear lamina for new EBV maturation and budding through the inner nuclear membrane [265]. The homolog proteins of BFLF2, HSV-1 UL31 ( $\alpha$-herpesvirus) [264] and HCMV UL53 ( $\beta$-herpesvirus) [266], also possess NLSs to mediate their nuclear import. HSV-1 UL31 has a functional bipartite NLS [264], whereas both HCMV UL53 [266] and EBV BFLF2 [267] have a functional monopartite NLS. BFLF2's nuclear import requires Ran, importin- $\alpha$ 7, importin- $\beta 1$, and importin- $\beta 2$, but not importins $\alpha 1, \alpha 3$, or $\alpha 5$ [267]. On the other hand, HSV-1 UL31 interacts with Ran, importin- $\alpha 1$, and importin- $\beta 2$ for its nuclear import $[268,269]$.

Non-functional NESs have been found in EBV BFLF2 [267] and HSV-1 UL31 [264,269], and no NESs have been found in HCMV UL53 [270]; these findings suggest that these proteins do not require Crm1 for their export. EBV BFLF2 interacts with Nxf1 in the absence of RNA for its export. The nuclear export receptors for HSV-1 UL31 and HCMV UL53 are yet to be determined [267]. Funk et al. conducted a comprehensive analysis on the EBV and HSV-1 tegument proteins using an in vitro assay called Nuclear EXport Trapped by RAPamycin (NEX-TRAP) [271] and found that two EBV (pBTRF1 and pBGFL3) and nine HSV-1 tegument proteins showed nuclear export activity. The group compared the nuclear export activity between the EBV and HSV-1 tegument orthologs; EBV pBTRF1 behaved in a similar way to its HSV-1 orthologue pUL21, exhibiting active export activity. Conversely, EBV pBGFL3 (exported) displayed the opposite behavior compared to its HSV-1 orthologue pUL14 (non-exported). The NES of pBTRF1 matches the Rev NES consensus, and that of pBGFL3 matches the PKI NES consensus. The NESs of both Rev and PKI are recognized by Crm1, which suggests that EBV pBTRF1's and pBGFL3's export activities are Crm1-dependent. A leptomycin B (LMB) assay revealed six HSV-1 tegument proteins (pUL4, pUL11, pUL13, pUL21, pUL37d11, and pUL48) that are exported in a Crm1-dependent manner. 
Table 2. Interactions between viral factors and host factors in the hijacking of the host nuclear transport machinery.

\begin{tabular}{|c|c|c|c|c|c|c|}
\hline Viral Family & Site of Replication & Virus Name & Viral Factors & Host Factors & $\begin{array}{l}\text { Effect of Viral-Host Factor } \\
\text { Interaction }\end{array}$ & References \\
\hline \multirow{9}{*}{$\begin{array}{c}\text { Coronaviridae } \\
(+ \text { ssRNA) }\end{array}$} & \multirow{9}{*}{ Cytoplasm } & \multirow{4}{*}{$\begin{array}{l}\text { SARS } \\
\text { CoV-2 }\end{array}$} & \multirow{3}{*}{ Orf6 } & Importin- $\alpha 1 / \beta 1$ & $\begin{array}{l}\text { Blocks nuclear } \\
\text { translocation of IRF3 to } \\
\text { suppress IFN } \beta \text { production. }\end{array}$ & \multirow{3}{*}[75,76,78]{} \\
\hline & & & & $\begin{array}{l}\text { Importin- } \alpha / \beta 1 \\
\text { (isoform } \alpha 1, \alpha 5 \text { ) }\end{array}$ & $\begin{array}{l}\text { Blocks nuclear } \\
\text { translocation of activated } \\
\text { STAT1/2 to suppress } \\
\text { IFN-mediated antiviral } \\
\text { response. }\end{array}$ & \\
\hline & & & & Nup98 and Rae1 & $\begin{array}{l}\text { Disrupts importin- } \alpha 5 / \beta 1 \\
\text { docking on Nup98-Rae1 } \\
\text { complex for nuclear } \\
\text { import. } \\
\text { Cytoplasmic accumulation } \\
\text { of Nup98 and Rae1. } \\
\text { Nuclear accumulation of } \\
\text { hnRNP A1. }\end{array}$ & \\
\hline & & & Nsp1 & Nxf1 & $\begin{array}{l}\text { Interrupts Nxf1 binds to } \\
\text { mRNA export adaptors } \\
\text { including Aly/REF and } \\
\text { UAP56. } \\
\text { Reduces interaction } \\
\text { between Nxf1 and Nups } \\
\text { (Nup98, Nup214, Nup358). }\end{array}$ & [83] \\
\hline & & \multirow{4}{*}{$\begin{array}{l}\text { SARS } \\
\text { CoV-1 }\end{array}$} & \multirow{3}{*}{ Nsp1 } & Importin- $\alpha 1 / \beta 1$ & $\begin{array}{l}\text { Connects importin- } \alpha 1 / \beta 1 \\
\text { at ER/Golgi to sequester } \\
\text { the receptor for activated } \\
\text { STAT1 nuclear import. }\end{array}$ & \multirow{3}{*}{$\begin{array}{r}{[79,80]} \\
{[84]}\end{array}$} \\
\hline & & & & Nup93 & $\begin{array}{l}\text { Mislocalization of Nup93 } \\
\text { (from NE to cytoplasm). }\end{array}$ & \\
\hline & & & & Nucleolin & $\begin{array}{l}\text { Cytoplasmic accumulation } \\
\text { with unknown reasons. }\end{array}$ & \\
\hline & & & Orf9b & Crm1 & $\begin{array}{l}\text { Nuclear export of Orf9b } \\
\text { prevents } \\
\text { Caspase-3-mediated } \\
\text { apoptosis. }\end{array}$ & [85] \\
\hline & & $\begin{array}{l}\text { MERS } \\
\mathrm{CoV}\end{array}$ & Orf4b & Importin- $\alpha 3 / \beta 1$ & $\begin{array}{l}\text { Blocks IFR3 and IRF7 } \\
\text { nuclear import for IFN } \beta \\
\text { production. } \\
\text { Blocks NF- } \kappa \text { B p } 65 \text { subunit } \\
\text { nuclear import to suppress } \\
\text { host } \\
\text { antiviral response. }\end{array}$ & {$[86,87]$} \\
\hline
\end{tabular}


Table 2. Cont.

\begin{tabular}{|c|c|c|c|c|c|c|}
\hline Viral Family & Site of Replication & Virus Name & Viral Factors & Host Factors & $\begin{array}{l}\text { Effect of Viral-Host } \\
\text { Factor Interaction }\end{array}$ & References \\
\hline \multirow[t]{4}{*}{$\begin{array}{c}\text { Filoviridae } \\
\text { (-ssRNA) }\end{array}$} & \multirow[t]{4}{*}{ Cytoplasm } & \multirow[t]{4}{*}{$\begin{array}{l}\text { Zaire } \\
\text { EBOV }\end{array}$} & \multirow[t]{2}{*}{ VP24 } & $\begin{array}{l}\text { Importin- } \alpha / \beta 1 \\
\text { (isoform: } \alpha 5, \alpha 6 \text {, } \\
\text { and } \alpha 7 \text { ) }\end{array}$ & $\begin{array}{l}\text { Blocks nuclear } \\
\text { translocation of } \\
\text { activated STAT1 to } \\
\text { suppress } \\
\text { IFN-mediated } \\
\text { antiviral response. }\end{array}$ & \multirow[t]{2}{*}[91,97]{} \\
\hline & & & & Importin- $\alpha 5 / \beta 1$ & $\begin{array}{l}\text { Cytoplasmic } \\
\text { accumulation of } \\
\text { hnRNP C1/C2 for } \\
\text { viral } \\
\text { replication. }\end{array}$ & \\
\hline & & & Inclusion body (IB) & Importin- $\alpha 7$ & $\begin{array}{l}\text { Required for IB } \\
\text { formation. }\end{array}$ & [104] \\
\hline & & & $\begin{array}{l}\text { Nucleo-protein } \\
\text { (NP) }\end{array}$ & Nxf1 & $\begin{array}{l}\text { Exports viral } \\
\text { mRNA from IB to } \\
\text { cytoplasm for } \\
\text { translation }\end{array}$ & [105] \\
\hline \multirow{5}{*}{$\begin{array}{c}\text { Flaviviridae } \\
\text { (+ssRNA) }\end{array}$} & \multirow[t]{5}{*}{ Cytoplasm } & \multirow[t]{3}{*}{ DENV } & \multirow[t]{2}{*}{ NS5 } & $\begin{array}{c}\text { Importin- } \alpha 2 / \beta 1 \\
\text { (DENV serotype } 2 \\
\text { and } 3 \text { only) }\end{array}$ & $\begin{array}{l}\text { Nuclear import of } \\
\text { NS5 has unclear } \\
\text { functions on viral } \\
\text { replication and } \\
\text { pathogenesis of the } \\
\text { disease. }\end{array}$ & \multirow[t]{2}{*}[115,116]{} \\
\hline & & & & Crm1 & $\begin{array}{l}\text { Nuclear export of } \\
\text { NS5 promote IL-8 } \\
\text { production and } \\
\text { suppress } \\
\text { viral replication. }\end{array}$ & \\
\hline & & & NS3 & $\begin{array}{l}\text { FG-Nups (Nup62, } \\
\text { Nup153, and } \\
\text { Nup98) }\end{array}$ & $\begin{array}{l}\text { Works in concert } \\
\text { with NS2B3 to } \\
\text { degrade FG-Nups. }\end{array}$ & [117] \\
\hline & & \multirow[t]{2}{*}{ ZIKV } & NS5 & $\begin{array}{l}\text { Importin- } \alpha / \beta 1 \\
\text { (isoform } \alpha 1, \alpha 3 \\
\alpha 4, \text { and } \alpha 7 \text { ) }\end{array}$ & $\begin{array}{l}\text { Protects NS5 from } \\
\text { cytoplasmic } \\
\text { degradation. } \\
\text { Sequesters } \\
\text { importins } \alpha \text { in } \\
\text { nuclear bodies. }\end{array}$ & $\begin{array}{l}{[122]} \\
{[123]}\end{array}$ \\
\hline & & & NS3 & $\begin{array}{c}\text { Nups (TPR, } \\
\text { Nup153, and } \\
\text { Nup98) }\end{array}$ & $\begin{array}{l}\text { Works in concert } \\
\text { with NS2B3 to } \\
\text { degrade Nups. }\end{array}$ & [117] \\
\hline
\end{tabular}


Table 2. Cont.

\begin{tabular}{|c|c|c|c|c|c|c|}
\hline Viral Family & $\begin{array}{c}\text { Site of } \\
\text { Replication }\end{array}$ & $\begin{array}{l}\text { Virus } \\
\text { Name }\end{array}$ & Viral Factors & Host Factors & Effect of Viral-Host Factor Interaction & References \\
\hline \multirow{3}{*}{$\begin{array}{l}\text { Togaviridae } \\
\text { (+ssRNA) }\end{array}$} & \multirow{3}{*}{ Cytoplasm } & \multirow{3}{*}{ CHIKV } & \multirow{2}{*}{$\begin{array}{l}\text { Capsid protein } \\
\text { (CP) }\end{array}$} & Importin- $\alpha 3 / \beta 1$ & Purpose of nuclear localization of $\mathrm{CP}$ is unclear. & \multirow{2}{*}[129,130]{} \\
\hline & & & & Crm1 & $\begin{array}{l}\text { Mutation in CP NES blocks host nuclear import with } \\
\text { unknown mechanisms. }\end{array}$ & \\
\hline & & & nsP2 & nil & $\begin{array}{l}\text { nsP2 does not have NLS but it can enter nucleus to } \\
\text { suppress } \\
\text { host immunity. }\end{array}$ & {$[131,135]$} \\
\hline \multirow{5}{*}{$\begin{array}{l}\text { Retroviridae } \\
(+ \text { ssRNA) }\end{array}$} & \multirow{5}{*}{ Nucleus } & \multirow{5}{*}{ HIV } & \multirow{2}{*}{$\begin{array}{l}\text { Viral Capsid } \\
\quad(\mathrm{CA})\end{array}$} & $\begin{array}{l}\text { Nup358 and } \\
\text { Nup62 }\end{array}$ & Nuclear import of viral capsid. & \multirow[t]{2}{*}{ [154] } \\
\hline & & & & $\begin{array}{l}\text { Nup153 and } \\
\text { CPSF6 }\end{array}$ & Disassembles viral capsid to release PIC to nucleus. & \\
\hline & & & Vpr & $\begin{array}{l}\text { Importin- } \alpha / \beta 1 \\
\text { (preferably to } \alpha 5 \text {, } \\
\text { lesser extend to } \\
\alpha 1 \text { and } \alpha 4 \text { ) } \\
\end{array}$ & $\begin{array}{l}\text { Inhibits IRF3 activation and to block nuclear import of } \\
\text { IRF3 } \\
\text { and Nf } k \text { B. }\end{array}$ & [155] \\
\hline & & & $\operatorname{Rev}$ & Importin $\beta 1$ & $\begin{array}{l}\text { Rev nuclear import is needed to form viral } \\
\text { ribonucleoprotein }\end{array}$ & {$[160,162-$} \\
\hline & & & KeV & $\begin{array}{l}\text { Nups (214, } \\
\text { Nup153, Nup98, } \\
\text { and Nup62) }\end{array}$ & $\begin{array}{l}\text { (vRNP) transport complex, and the complex is then } \\
\text { exported } \\
\text { out by Crm1. }\end{array}$ & 165] \\
\hline \multirow{8}{*}{$\begin{array}{l}\text { Orthomyxoviridae } \\
\text { (-ssRNA) }\end{array}$} & \multirow{8}{*}{ Nucleus } & \multirow{8}{*}{$\begin{array}{l}\text { Influenza } \\
\text { A }\end{array}$} & $\begin{array}{l}\text { Nucleo-protein } \\
\text { (NP) }\end{array}$ & $\begin{array}{l}\text { Importin- } \alpha / \beta 1 \\
\text { (isoform: } \alpha 5, \alpha 7 \text { ) }\end{array}$ & vRNP nuclear import for viral replication. & {$[170,173]$} \\
\hline & & & $\begin{array}{l}\text { PA-PB1 (RdRP } \\
\text { subunit) }\end{array}$ & Importin 5 & $\begin{array}{l}\text { Forms an import complex with PA and PB1, but also } \\
\text { regulates PA-PB1 complex for vRNA binding. }\end{array}$ & {$[180,181]$} \\
\hline & & & \multirow[t]{2}{*}{$\begin{array}{l}\text { PB2 (RdRP } \\
\text { subunit) }\end{array}$} & $\begin{array}{l}\text { Importin- } \alpha / \beta 1 \\
\text { (isoform: } \alpha 1, \alpha 5 \text {, } \\
\alpha 7 \text { ) }\end{array}$ & $\begin{array}{l}\text { vRNP nuclear import for viral replication. } \\
\text { Importin- } \alpha \text { isoform switching for viral adaptation in } \\
\text { different } \\
\text { host species. }\end{array}$ & $\begin{array}{c}{[176-178]} \\
{[272]}\end{array}$ \\
\hline & & & & Importin- $\alpha 3 / \beta 1$ & $\begin{array}{l}\text { Negatively regulate PB2 polymerase activity. } \\
\text { Downregulates importin- } \alpha 3 \text { expression to suppress } \\
\text { host } \\
\text { antiviral response by blocking NF- } \mathrm{kB} \text { nuclear import. }\end{array}$ & $\begin{array}{l}{[177]} \\
{[179]}\end{array}$ \\
\hline & & & NS2 & Crm1 & Forms an export complex with vRNP, viral M1 protein. & {$[182,183]$} \\
\hline & & & \multirow[t]{2}{*}{ NS1 } & Nup98 & $\begin{array}{l}\text { Downregulation of Nup98 expression to inhibit host } \\
\text { mRNA } \\
\text { export. }\end{array}$ & \multirow[t]{2}{*}{ [184] } \\
\hline & & & & Nxf1 & $\begin{array}{l}\text { Binds to FG-repeat binding site of Nxf1 to block host } \\
\text { mRNA } \\
\text { export. }\end{array}$ & \\
\hline & & & vRNA & $\begin{array}{c}\text { Nxf1 } \\
\text { Nup62 }\end{array}$ & $\begin{array}{l}\text { In severe influenza infection, vRNA binds to Nxf1 } \\
\text { alone and interacts only with Nup62 for nuclear export. }\end{array}$ & [188] \\
\hline
\end{tabular}


Table 2. Cont.

\begin{tabular}{|c|c|c|c|c|c|c|}
\hline Viral Family & $\begin{array}{c}\text { Site of } \\
\text { Replication }\end{array}$ & $\begin{array}{l}\text { Virus } \\
\text { Name }\end{array}$ & Viral Factors & Host Factors & Effect of Viral-Host Factor Interaction & References \\
\hline \multirow{11}{*}{$\begin{array}{l}\text { Papillomaviridae } \\
\text { (dsDNA) }\end{array}$} & \multirow{11}{*}{ Nucleus } & \multirow{11}{*}{$\mathrm{HPV}$} & High-risk E6 & $\begin{array}{c}\text { Importin- } \\
\alpha 1 / \beta 1 \\
\text { Importin- } \beta 1 \\
\text { Importin- } \beta 2\end{array}$ & $\begin{array}{l}\text { Mediates polyubiquitination of p53 for proteasome } \\
\text { degradation independent of MDM } 2 \text {. }\end{array}$ & {$[194,196,197]$} \\
\hline & & & \multirow[t]{2}{*}{ High-risk E7 } & $\begin{array}{l}\text { FG-Nups } \\
\text { (Nup62 and } \\
\text { Nup153) }\end{array}$ & $\begin{array}{l}\text { Re-programs cell cycle to S-phase to support viral DNA } \\
\text { amplification. }\end{array}$ & [202] \\
\hline & & & & Crm1 & Nuclear export of E7. & [200] \\
\hline & & & \multirow[t]{2}{*}{ E1 } & $\begin{array}{l}\text { Importin- } \\
\alpha / \beta 1 \text { (isoform: } \\
\alpha 1, \alpha 3, \alpha 5)\end{array}$ & $\begin{array}{l}\text { Phosphorylation of E1 by host ERK and/or JNK is needed } \\
\text { to } \\
\text { enable E1 binds importins } \alpha \text { for nuclear import for viral } \\
\text { replication. }\end{array}$ & [205-207] \\
\hline & & & & CDK & $\begin{array}{l}\text { Phosphorylation of E1 blocks Crm1-dependent export to } \\
\text { retain E1 in nucleus for viral replication. }\end{array}$ & {$[204,208]$} \\
\hline & & & \multirow[t]{2}{*}{ E2 } & $\begin{array}{c}\text { Unknown } \\
\text { import NTR }\end{array}$ & Nuclear import of E2 is needed for viral replication. & {$[210]$} \\
\hline & & & & Crm1 & $\begin{array}{l}\text { Cytoplasmic accumulation of high-risk E2 induces } \\
\text { caspase- } 8 \\
\text { mediated cell apoptosis. }\end{array}$ & [209] \\
\hline & & & \multirow{2}{*}{$\begin{array}{l}\text { L1 major } \\
\text { capsid }\end{array}$} & $\begin{array}{c}\text { Importin } \\
\alpha 1 / \beta 1\end{array}$ & Capsid proteins assembly in nucleus. & \multirow[t]{2}{*}{ [211] } \\
\hline & & & & Importin $\beta 2$ & Inhibits nuclear import of hnRNP A1. & \\
\hline & & & \multirow{2}{*}{$\begin{array}{l}\text { L2 minor } \\
\text { capsid }\end{array}$} & $\begin{array}{c}\text { Importin } \\
\alpha 1 / \beta 1\end{array}$ & \multirow{2}{*}{ Capsid proteins assembly in nucleus. } & \multirow{2}{*}{ [212] } \\
\hline & & & & $\begin{array}{c}\text { Importin } \beta 2 \\
\text { Importin } 5\end{array}$ & & \\
\hline \multirow{5}{*}{$\begin{array}{l}\text { Hepadnaviridae } \\
\text { (dsDNA) }\end{array}$} & \multirow{5}{*}{ Nucleus } & \multirow{5}{*}{ HBV } & \multirow{4}{*}{$\begin{array}{l}\text { Capsid protein } \\
(\mathrm{Cp})\end{array}$} & $\begin{array}{c}\text { Importin } \\
\alpha 1 / \beta 1 \\
\end{array}$ & $\begin{array}{l}\text { Viral capsid binds to classical importin } \alpha / \beta 1 \text { to pass } \\
\text { through NPC. Capsid disassembly starts once it interacts }\end{array}$ & \multirow[t]{2}{*}[216,217,219]{} \\
\hline & & & & Nup153 & with Nup 153 & \\
\hline & & & & Nxf1 & pgRNA export for virion production. & \multirow{2}{*}[220,221]{} \\
\hline & & & & Crm-1 & $\begin{array}{l}\text { pgRNA export for virion production (when nuclear } \mathrm{Cp} \\
\text { concentration is high). }\end{array}$ & \\
\hline & & & p22 (HBeAg) & $\begin{array}{c}\text { Importin- } \\
\alpha 5 / \beta 1\end{array}$ & $\begin{array}{l}\text { Blocks activated STAT1 nuclear import to suppress host } \\
\text { antiviral response. }\end{array}$ & [223] \\
\hline
\end{tabular}


Table 2. Cont.

\begin{tabular}{|c|c|c|c|c|c|c|}
\hline Viral Family & $\begin{array}{c}\text { Site of } \\
\text { Replication }\end{array}$ & Virus Name & Viral Factors & Host Factors & Effect of Viral-Host Factor Interaction & References \\
\hline \multirow{22}{*}{$\begin{array}{l}\text { Herpesviridae } \\
\text { (dsDNA) }\end{array}$} & \multirow{22}{*}{ Nucleus } & \multirow{6}{*}{ HSV-1 } & $\mathrm{VP1} / 2$ & Importin- $\beta 1$ & \multirow{2}{*}{$\begin{array}{l}\text { Viral capsid docking on NPC to deliver viral DNA to } \\
\text { nucleus. }\end{array}$} & \multirow{2}{*}[225,226]{} \\
\hline & & & pUL25 & Nup358, Nup214 & & \\
\hline & & & pUL30 & Importin- $\alpha 5 / \beta 1$ & \multirow{2}{*}{$\begin{array}{l}\text { Nuclear localization of pUL30 and pUL42 is needed } \\
\text { for viral } \\
\text { replication in host nucleus. }\end{array}$} & \multirow{2}{*}{ [230-233] } \\
\hline & & & pUL42 & $\begin{array}{l}\text { Importin- } \alpha / \beta 1 \\
\text { (isoform: } \alpha 1 \text { and } \\
\alpha 7 \text { ) }\end{array}$ & & \\
\hline & & & ICP27 & Aly/REF, Nxf1 & Viral mRNA export for viral protein translation. & [237] \\
\hline & & & gM & Exportin-6 (XPO6) & Nuclear export of gM to TGN. & [241] \\
\hline & & & pUL97 & Importin- $\alpha 1 / \beta 1$ & $\begin{array}{l}\text { Phosphorylates CDK1 and modifies G2/M cell cycle } \\
\text { checkpoint regulators to promote viral replication. }\end{array}$ & {$[244,245]$} \\
\hline & & HCMV & pUL79 & Importin- $\beta 2$ & $\begin{array}{l}\text { Function as an elongation factor of RNA polymerase } \\
\text { II for } \\
\text { viral gene transcription in nucleus. }\end{array}$ & {$[246,247]$} \\
\hline & & & \multirow[t]{2}{*}{ pUL84 } & $\begin{array}{l}\text { Importin- } \alpha / \beta 1 \\
\text { (isoform } \alpha 1, \alpha 3, \alpha 4 \text {, } \\
\text { and } \alpha 5 \text { ) }\end{array}$ & Initiate lytic viral DNA synthesis in nucleus. & {$[248,249]$} \\
\hline & & & & Crm1 & Viral mRNA export (IRS1 transcript) & [248] \\
\hline & & & pUL69 & $\begin{array}{l}\text { UAP56/URH49, } \\
\text { hSPT6, Nxf1 }\end{array}$ & Viral mRNA export & [253] \\
\hline & & \multirow{11}{*}{ EBV } & EBNA1 & $\begin{array}{l}\text { Importin- } \alpha / \beta 1 \\
\text { (isoform: } \alpha 1, \alpha 5 \text { ) }\end{array}$ & $\begin{array}{l}\text { Nuclear EBNA1 tethers viral episomal DNA to host } \\
\text { chromosome in latent phase. }\end{array}$ & [257] \\
\hline & & & \multirow[t]{3}{*}{ BGLF4 } & RanGAP1 & $\begin{array}{l}\text { Nuclear accmulation of RanGAP1 inhibits nuclear } \\
\text { import of } \\
\text { cNLS-bearing cargoes. }\end{array}$ & \multirow[t]{3}{*}{ [258] } \\
\hline & & & & $\begin{array}{l}\text { FG-Nups (Nup62 } \\
\text { and Nup153) }\end{array}$ & $\begin{array}{l}\text { Phosphorylation of FG-Nups dilates NPC pores to } \\
\text { facilitate } \\
\text { nuclear import of non-NLS-bearing viral proteins. }\end{array}$ & \\
\hline & & & & Microtubule & $\begin{array}{l}\text { Reorganizes nucleus shape to allow nuclear import } \\
\text { of non- } \\
\text { NLS-bearing viral proteins. }\end{array}$ & \\
\hline & & & EGR1 & Importin-7 (IPO7) & Negatively regulates importin-7 expression to a level & \multirow{2}{*}{ [261] } \\
\hline & & & EBV miRNA & Exportin-5 (XPO5) & that is optimal for EBV-transformed cell growth. & \\
\hline & & & \multirow[t]{2}{*}{ EB2 } & Crm1 & $\begin{array}{l}\text { Boosts EB2-mediated gene expression and mediate } \\
\text { unspliced } \\
\text { lytic EBV mRNA export }\end{array}$ & \multirow[t]{2}{*}{ [263] } \\
\hline & & & & Nup214 & EBV mRNA export for translation. & \\
\hline & & & \multirow[t]{2}{*}{$\begin{array}{l}\text { BFLF2 (Nuclear } \\
\text { egress protein } \\
\text { 1) }\end{array}$} & $\begin{array}{l}\text { Ran, } \\
\text { Importin- } \alpha 7 / \beta 1 \\
\text { Importin- } \beta 2\end{array}$ & $\begin{array}{l}\text { Interacts with BFRF1 (nuclear egress protein 2) at } \\
\text { inner } \\
\text { nuclear membrane to form nuclear egress complex } \\
\text { (NEC). }\end{array}$ & {$[265,267]$} \\
\hline & & & & Nxf1 & $\begin{array}{l}\text { Interacts with Nxf1 for BFLF2 nuclear export } \\
\text { without RNA } \\
\text { participation }\end{array}$ & [267] \\
\hline & & & $\begin{array}{l}\text { Tegument } \\
\text { proteins } \\
\text { (pBTRF1 and } \\
\text { pBGFL3) }\end{array}$ & Crm1 & $\begin{array}{l}\text { Assembles with viral nucleocapsid for } \\
\text { tegumentation in } \\
\text { cytoplasm. }\end{array}$ & [271] \\
\hline
\end{tabular}

\section{Potential Antiviral Drugs That Target the Host Nuclear Transport Machinery}

The exploitation by viruses of the host nucleocytoplasmic trafficking is crucial for viral genome replication, viral component assembly, suppression of the host antiviral response, and cellular state alteration. To date, viral polymerase inhibitors are actively used in clinics against various RNA and DNA viruses including EBOV [273], HIV [274], and HPV [275]. In addition to viral polymerase inhibitors, nuclear transport inhibitors can also be considered to reduce the viral load and/or ameliorate clinical symptoms, either in monotherapy or in combination with other antiviral agents. In this section, we discuss the host-specific and the viral-specific nuclear transport inhibitors and relevant clinical trials. The key points are summarized in Tables 3 and 4.

\subsection{Host-Specific Nuclear Import Inhibitors}

The importin- $\alpha / \beta 1$ heterodimer is a common NTR used by many viruses for nuclear entry. Importin- $\alpha$ inhibitors include Bimax (1 and 2) [276], cSN50.1 [277,278], Ivermectin [279,280], and GW5074 [281]. Among these drugs, only cSN50.1 is an importin- $\alpha$ isoform-specific inhibitor; it targets importin- $\alpha 5$ [278]. Both of the small molecule inhibitors, Ivermectin [282] and GW5074 (a c-Raf inhibitor) [281], share the same inhibitory mechanism. They bind to importin- $\alpha$ to block cargo loading and the formation of the importin- $\alpha / \beta 1$ heterodimer. Ivermectin has a broad-spectrum in vitro and/or in vivo an- 
tiviral effect against different types of RNA and DNA viruses, including SARS-CoV-2 (see Table 3). GW5074 has in vitro antiviral activity against two types of flaviviruses, DENV2 and ZIKV [282].

Importin- $\beta$ inhibitors can directly block the formation of the cargo-receptor ternary complex. Several importin- $\beta$ inhibitors, including three importin- $\beta 1$ inhibitors (Importazole [283], INI-43 [284], and Karyostatin [285]) and the importin- $\beta 2$ inhibitor M9M [286], have been studied for their nuclear import blockade activity in cancer cells. Thus far, only M9M has been tested for its antiviral effects; it was found to block the nuclear import of HSV-1 UL6 [287].

\subsection{Host-Specific Nuclear Export Inhibitors}

As Crm1 is crucial for the nuclear export of a vast number of cargo types, it is a main target of viruses for the export of their proteins. LMB and its derivatives [288,289], as well as selective inhibitor for nuclear export (SINE) [290,291] compounds, target a common site of Crm1, Cysteine-528, to block Crm1 from interacting with the NES-bearing cargo. After it binds to Crm1, LMB undergoes hydrolysis and subsequently forms a salt bridge in LMB-Crm1, irreversibly inhibiting Crm1's function [292]. Conversely, SINEs do not undergo hydrolysis after they bind to Crm1; therefore, there is no salt bridge formation $[293,294]$. However, the SINE-Crm1 interaction promotes Crm1 degradation, and Crm1 re-synthesis occurs after SINE administration is discontinued [295]. Clinical trials of LMB were halted because the treatment caused profound adverse effects, presumably owing to the irreversible LMB-Crm1 interaction [296]. Conversely, SINEs have shown much lower toxicity in clinical trials because their inhibition of Crm1's function is reversible (reviewed in [297]). The SINEs Selinexor and Verdinexor, which have been actively tested in cancer patients, are now under evaluation for their antiviral activity in in vitro and in vivo settings (Table 3 ).

\subsection{Viral-Specific Nuclear Transport Inhibitors}

$\mathrm{N}$-(4-hydroxyphenyl) retinamide (4-HRP or Fenretinide) targets Flavivirus polymerase NS5 and prevents NS5 nuclear import. 4-HRP has both therapeutic and prophylactic potential against DENV and ZIKV [298-300]. Not only is 4-HRP effective against four DENV serotypes, but it also prevents the antibody-dependent enhancement (ADE) of dengue hemorrhagic fever (DHF) [300]. A blockade of ZIKV NS5 nuclear accumulation in neurons could protect neurons from inflammation, thus reducing the risk of neurological disorders due to ZIKV infection [123].

Two potent HIV capsid inhibitors, GS-6207 and GS-CA, have been developed by Gilead Science [301,302]. These small molecule inhibitors bind to the HIV capsid protein, impeding the delivery of viral PIC into the host nucleus and thus interrupting capsid assembly and viral particle production. The binding site of the inhibitors is the site where Nup153 and CPSF6 bind during the HIV capsid's nuclear entry.

Mohl et al. developed a model for an IAV PB1/PA-RanBP5 complexation, and then used PPI software-based virtual screening to identify potential inhibitors that target IAV PB1 and block its interaction with importin-5 (RanBP5) [303]. In vitro studies have shown that five compounds may inhibit the nuclear localization and in vitro polymerase activity of PB1/PA.

Some groups have applied in silico screening to identify inhibitors of EBOV VP24 and importin- $\alpha$ isoforms. Tanaka et al. used a CE-SELEX system to select oligonucleotide-based VP24-binding aptamers that inhibit the VP24-importin- $\alpha 1$ interaction [304]. Two of these inhibitors, VPKS-2 and VPKS-5, were found to inhibit the VP25-importin- $\alpha 5$ interaction in vitro. Another research team, Song et al., utilized the Random non-standard Peptides Integrated Discovery (RaPID) system to design high-affinity macrocyclic peptides that compete with importin- $\alpha 6$ for VP24 binding [305]. These strategies protect importins $\alpha$ from VP24, and thus restores the host antiviral defense system during infection. 
The therapeutic effects of interferon $\beta$ (type-I interferon) on recurrent HPV infection lesions have been clinically proven, especially in patients with cervical intraepithelial neoplasia (CIN) [306]. Type I IFN strongly induces p56 expression, and p56 binds the E1 protein of several HPV serotypes [307]. In vivo experiments demonstrated that cytoplasmic p56 promotes the nuclear export of the E1 protein [307]. Other in vitro experiments revealed that recombinant p56 inhibits the DNA helicase activity of E1, consequently halting HPV DNA replication [307].

The nucleocytoplasmic trafficking of HBV core/capsid proteins is required for HBV to successfully infect adjacent healthy hepatocytes and to persistently re-infect HBV-infected hepatocytes. Capsid assembly modulators (CAMs), including heteroaryldihydropyrimidines (HAPs) [308-310], phenylpropenamides (PPAs) [311-313], and sulfamoylbenzamides (SBAs) [314], are studied for their anti-HBV efficacies. CAMs can reduce HBV cccDNA levels through several mechanisms. For example, they can block the nuclear entry of HBV nucleocapsids, which circumvent persistent infection in HBV-infected cells or inhibit cccDNA formation in newly HBV-infected cells $[315,316]$, and they can disrupt the structural integrity of cccDNA (reviewed in [317]).

Table 3. Types of Nuclear Transport Inhibitors with Antiviral Activities.

\begin{tabular}{|c|c|c|c|c|c|}
\hline Types of Inhibitors & Compound & Target & Target Viruses & Types of Studies & References \\
\hline \multirow{13}{*}{$\begin{array}{l}\text { Host-specific nuclear } \\
\text { import inhibitors }\end{array}$} & \multirow{10}{*}{ Ivermectin } & \multirow{10}{*}{ Importin $\alpha$} & SARS-CoV-2 & In vitro & [318] \\
\hline & & & DENV1 (EDEN-1) & In vitro and in vivo & \multirow{4}{*}{ [279] } \\
\hline & & & DENV2 (EDEN-2) & In vitro and in vivo & \\
\hline & & & DENV3 (EDEN-3) & In vitro and in vivo & \\
\hline & & & DENV4 (EDEN-4) & In vitro and in vivo & \\
\hline & & & DENV2 (NGC) & In vitro and in vivo & [282] \\
\hline & & & $\begin{array}{l}\text { ZIKAV (Asian/Cook } \\
\text { Island/ 2014) }\end{array}$ & In vitro and in vivo & [282] \\
\hline & & & CHIKV-Rluc & In vitro & [319] \\
\hline & & & $\begin{array}{c}\text { Adenovirus } \\
\text { (HAdV-C5 and } \\
\text { HAdV-B3) }\end{array}$ & In vitro and in vivo & [320] \\
\hline & & & $\begin{array}{c}\text { BK polyomavirus } \\
(\mathrm{BKPyV})\end{array}$ & In vitro & [321] \\
\hline & \multirow{2}{*}{ GW5074 } & \multirow{2}{*}{ Importin $\alpha$} & DENV2 (NGC) & In vitro & [281] \\
\hline & & & $\begin{array}{l}\text { ZIKAV (Asian/Cook } \\
\text { Island/ 2014) }\end{array}$ & In vitro & [281] \\
\hline & M9M & Importin $\beta 2$ & HSV-1 & In vivo & [287] \\
\hline \multirow{2}{*}{$\begin{array}{c}\text { Host-specific nuclear } \\
\text { export inhibitors }\end{array}$} & Selinexor & Crm1 & SARS-CoV-2 & In vitro & [322] \\
\hline & Verdinexor & Crm1 & IAV & In vitro and in vivo & {$[323,324]$} \\
\hline \multirow{7}{*}{$\begin{array}{l}\text { Virus-specific nuclear } \\
\text { transport inhibitors }\end{array}$} & 4-HRP & NS5 & $\begin{array}{c}\text { Flaviviruses (DENV, } \\
\text { ZIKV) }\end{array}$ & In vitro and in vivo & [298-300] \\
\hline & GS-6207 and GS-CA & Capsid Protein & HIV-1 and HIV-2 & In vitro and in vivo & {$[301,302]$} \\
\hline & $\begin{array}{l}\text { Small-molecule } \\
\text { inhibitor }\end{array}$ & PB1 & IAV & In vitro and in vivo & [303] \\
\hline & VPKS-2 and -5 & VP24 & EBOV & In vitro & [304] \\
\hline & $\begin{array}{c}\text { High-affinity } \\
\text { macrocyclic peptide }\end{array}$ & VP24 & EBOV & In vitro & [305] \\
\hline & Type-I IFN & E1 & HPV & In vitro & [307] \\
\hline & $\begin{array}{l}\text { Capsid Assembly } \\
\text { Modulator }\end{array}$ & $\begin{array}{l}\text { Core/Capsid } \\
\text { Protein }\end{array}$ & HBV & In vitro and in vivo & [308-314] \\
\hline
\end{tabular}

\subsection{Clinical Translation of Nuclear Transport Inhibitors against Viral Infections}

Regarding the importin- $\alpha$ inhibitors, only Ivermectin has been assessed in clinical studies for its antiviral efficacy. Three clinical studies have been performed to evaluate the clinical benefits of Ivermectin in patients with COVID-19 [325-327]. Two of these clinical studies (one randomized clinical trial (RCT) and one non-RCT) found that Ivermectin, either in monotherapy [327] or in combination therapy [326], significantly improved the viral clearance in patients with mild cases of COVID-19. However, another clinical study on Ivermectin monotherapy found that it did not shorten the time required for symptom resolution in patients with mild cases of COVID-19 [325]. The observed clinical and immunological spectra of patients with COVID-19 indicate that viral clearance may not directly correlate with symptom resolution because symptoms that are induced by a dysregulated immune response can persist after successful viral clearance [328]. The synergism between Ivermectin and Remdesivir for treating COVID-19 has not yet been evaluated. 
In patients with dengue fever, a phase two RCT trial showed that Ivermectin monotherapy promoted NS1 antigenemia clearance but not viral clearance [329]. The serum NS1 level is positively correlated with dengue hemorrhagic fever (DHF) [330]. The role of Ivermectin in reducing the risk of DHF development in patients with dengue fever has not yet been investigated.

Two SINE candidates, Selinexor and Verdinexor, are actively being tested as therapeutics in cancer patients. Currently, one clinical trial (NCT04349098) has completed to determine the clinical benefits of Selinexor in treating moderate-to-severe cases of COVID19. Additionally, a recently completed phase one clinical trial (NCT02431364) reported that Verdinexor exhibited an improved adverse effect profile in healthy volunteers. However, the study has been terminated for administrative reasons.

Viral factor-specific nuclear transport inhibitors, such as GS-6207, REBACIN ${ }^{\circledR}$, and CAM (NVR 3-778 and GLS4), are currently being tested in clinical trials. A phase one clinical trial of GS-6207 (NCT07379866) found that a single dose of subcutaneously administered GS-6207 effectively reduced the plasma HIV viral load and that the protection could persist for more than six months [301]. In two parallel RCTs, REBACIN ${ }^{\circledR}$ was found to induce a strong viral clearance in HPV-positive patients [331]. Mechanistically, REBACIN ${ }^{\circledR}$ inhibits the mRNA transcription of high-risk HPV E6 and E7 oncoproteins in mice [331]. In addition, Yang et al. performed a retrospective analysis and a meta-analysis and found that REBACIN ${ }^{\circledR}$ showed better efficacy than IFN for treating a persistent high-risk HVP infection [332]. Yuen et al. performed a phase one RCT to test the anti-HBV activity of an SBA class CAM, NVR 3-778, in patients with chronic HBV infection without cirrhosis [333]. It revealed that NVR 3-778 was well-tolerated by patients and that this CAM compound could reduce the viral load (as measured by viral DNA and RNA levels); furthermore, its administration with pegylated IFN (pegIFN) produced a synergetic antiviral effect [333]. Zhang et al. reported that a HAP class CAM, GLS4, demonstrated antiviral activity in patients with a chronic HBV infection in a phase 1b study, and that this drug was welltolerated by patients [334]. 
Table 4. Clinical Trials of Various Nuclear Transport Inhibitors in Treating Viral Infections.

\begin{tabular}{|c|c|c|c|c|c|c|c|c|}
\hline Drugs & Disease & $\begin{array}{c}\text { Clinical Trial } \\
\text { Identifier }\end{array}$ & Study Design & Phase & $\begin{array}{l}\text { Dose and } \\
\text { Duration }\end{array}$ & $\begin{array}{c}\text { Main } \\
\text { Outcomes } \\
\text { and Measures }\end{array}$ & Results & References \\
\hline \multirow{5}{*}{ Ivermectin } & \multirow[t]{5}{*}{ COVID-19 } & NCT04405843 & $\begin{array}{l}\text { Double-blind } \\
\text { RCT: Placebo } \\
\text { (n: 200) vs. } \\
\text { Ivermectin } \\
\text { (n: 200) }\end{array}$ & $\begin{array}{c}\text { Phases } 2 \\
\text { and } 3\end{array}$ & $\begin{array}{c}\text { Oral } \\
\text { Ivermectin } \\
300 \mu \mathrm{g} / \mathrm{kg} \text { of } \\
\text { body weight } \\
\text { for } 5 \text { days }\end{array}$ & $\begin{array}{l}\text { Time to } \\
\text { resolution of } \\
\text { symptoms } \\
\text { within a } \\
\text { 21-day } \\
\text { follow-up } \\
\text { period }\end{array}$ & $\begin{array}{c}\text { Ivermectin did } \\
\text { not } \\
\text { significantly } \\
\text { shorten time } \\
\text { to resolution } \\
\text { of symptoms }\end{array}$ & [325] \\
\hline & & NCT04392427 & $\begin{array}{l}\text { Non-RCT: } \\
\text { Standard Care } \\
\text { Therapy (n: 61) } \\
\text { vs. Combined } \\
\text { Antiviral } \\
\text { Therapy (n: 69) }\end{array}$ & Phase 1 & $\begin{array}{c}\text { S.C.T: } \\
\text { Paracetamol } \\
\text { tablets (3 } \\
\text { times/day), } \\
\text { Zinc } \\
\text { supplement (2 } \\
\text { times/day), } \\
\text { Azithromycin } \\
\text { (case by case) } \\
\text { C.A.T: } \\
\text { Nitazoxanide } \\
\text { (500mg/6 h), } \\
\text { Ribavirin } \\
\text { 1200mg } \\
\text { (400mg } \\
\text { divided } \\
\text { doses), } \\
\text { Ivermectin } \\
\text { (following } \\
\text { weight } \\
\text { schedules) }\end{array}$ & $\begin{array}{l}\text { Viral clearance } \\
\text { rate }\end{array}$ & $\begin{array}{c}\text { Viral clearance } \\
\text { rate was } \\
\text { significantly } \\
\text { higher in CAT } \\
\text { compared } \\
\text { with SCT } \\
\text { group (CAT vs. } \\
\text { SCT } 58.1 \% \text { : } 0 \% \\
\text { on day } 7 ; \\
73.1 \%: 13.7 \% \\
\text { on day } 15 \text { ) }\end{array}$ & [326] \\
\hline & & \multirow[t]{3}{*}{ NCT04407130 } & \multirow[t]{3}{*}{$\begin{array}{l}\text { Double-blind } \\
\text { RCT: Placebo, } \\
\text { Ivermectin, } \\
\text { Ivermectin + } \\
\text { Doxycycline } \\
\text { (n:24/group) }\end{array}$} & \multirow[t]{3}{*}{ Phase 2} & \multirow{3}{*}{$\begin{array}{c}\text { Oral } \\
\text { Ivermectin } \\
\text { (12mg/day), } \\
\text { Doxycycline } \\
\text { (200mg on day } \\
1, \text { followed by } \\
\text { 100mg/12hours) } \\
\text { for } 5 \text { days }\end{array}$} & \multirow[t]{3}{*}{$\begin{array}{c}\text { Viral clearance } \\
\text { and remission } \\
\text { of } \\
\text { clinical } \\
\text { symptoms } \\
\text { (fever, cough) }\end{array}$} & $\begin{array}{c}\text { Ivermectin } \\
\text { monotherapy } \\
\text { significantly } \\
\text { enhanced } \\
\text { viral clearance } \\
\text { (Ivermectin vs. } \\
\text { placebo: } 9.7 \\
\text { days: } 12.7 \\
\text { days). }\end{array}$ & \multirow[t]{3}{*}{ [327] } \\
\hline & & & & & & & $\begin{array}{c}\text { No significant } \\
\text { difference } \\
\text { between the } \\
\text { placebo group } \\
\text { and } \\
\text { Ivermectin + } \\
\text { Doxycycline } \\
\text { group. }\end{array}$ & \\
\hline & & & & & & & $\begin{array}{l}\text { No significant } \\
\text { improvement } \\
\text { in clinical } \\
\text { symptoms } \\
\text { (fever, cough, } \\
\text { sore throat) }\end{array}$ & \\
\hline
\end{tabular}


Table 4. Cont.

\begin{tabular}{|c|c|c|c|c|c|c|c|c|}
\hline Drugs & Disease & $\begin{array}{c}\text { Clinical Trial } \\
\text { Identifier }\end{array}$ & Study Design & Phase & Dose and Duration & $\begin{array}{c}\text { Main Outcomes } \\
\text { and Measures }\end{array}$ & Results & References \\
\hline \multirow{3}{*}{$\begin{array}{l}\text { GS-6207 } \\
\text { (Lenaca- } \\
\text { pavir) }\end{array}$} & & NCT04390022 & $\begin{array}{l}\text { Double-blind RCT: } \\
\text { Placebo vs. } \\
\text { Ivermectin (n: } \\
\text { 12/group) }\end{array}$ & Phase 2 & $\begin{array}{c}\text { Oral Ivermectin } \\
(400 \mu \mathrm{g} / \mathrm{kg}) \text { for } 7 \text { days }\end{array}$ & $\begin{array}{c}\text { Proportion of } \\
\text { patients with } \\
\text { detectable } \\
\text { SARS-CoV-2 } \\
\text { RNA by PCR } \\
\text { from } \\
\text { nasopharynx- } \\
\text { geal swab at day } \\
7 \text { post-treatment. }\end{array}$ & $\begin{array}{l}\text { Ivermectin did not } \\
\text { significantly reduce } \\
\text { viral loads, but } \\
\text { Ivermectin-treated } \\
\text { patients recovered } \\
\text { faster from } \\
\text { hyposmia/ } \\
\text { anosmia. } \\
\end{array}$ & [335] \\
\hline & $\begin{array}{l}\text { Dengue } \\
\text { Fever }\end{array}$ & NCT02045069 & $\begin{array}{l}\text { Two consecutive } \\
\text { double-blind RCT: } \\
\text { Placebo (n:103) vs. } \\
\text { Ivermectin: (n:100) }\end{array}$ & $\begin{array}{l}\text { Phase } 2 \\
\text { then pro- } \\
\text { ceeded to } \\
\text { Phase } 3\end{array}$ & $\begin{array}{l}\text { Phase 2: } 2 \text { or } 3 \text { days of } \\
\text { 400 } \mu \mathrm{g} / \mathrm{kg} / \text { day } \\
\text { Ivermectin. } \\
\text { Phase } 3: 3 \text { days of } \\
\text { 400/ } \mathrm{kg} / \text { day Ivermectin }\end{array}$ & $\begin{array}{l}\text { Clinical progress } \\
\text { and drug side } \\
\text { effects }\end{array}$ & $\begin{array}{c}\text { Ivermectin } \\
\text { significantly } \\
\text { improved NS1 } \\
\text { antigenemia } \\
\text { clearance time. The } \\
\text { proportion of } \\
\text { patients with } \\
\text { detectable plasma } \\
\text { NS1 was } \\
\text { significantly lower } \\
\text { in } \\
\text { Ivermectin group } \\
\text { compared to } \\
\text { placebo. } \\
\text { No significant } \\
\text { difference in } \\
\text { viremia clearance } \\
\text { time between two } \\
\text { groups } \\
\text { Reduction in } \\
\text { plasma HIV RNA } \\
\text { in a } \\
\text { dose-dependent } \\
\text { fashion }\end{array}$ & [329] \\
\hline & HIV & NCT03739866 & $\begin{array}{l}\text { Double-blind RCT: } \\
\text { Placebo (n: 8) vs. } \\
\text { GS-6207 } \\
\text { (n: } 32)\end{array}$ & Phase 1 & $\begin{array}{c}\text { Four GS-6207 groups in } \\
\text { dose escalation fashion: } \\
20,50,150,450 \mathrm{mg}, \\
\text { daily single } \\
\text { subcutaneous dose for } 9 \\
\text { days }\end{array}$ & $\begin{array}{l}\text { Virus clearance } \\
\text { assessment, drug } \\
\text { resistant } \\
\text { assessment }\end{array}$ & $\begin{array}{c}\text { Resistant strain } \\
\text { was found in one } \\
\text { patient given } 20 \mathrm{mg} \\
\text { GS-6207. Results } \\
\text { showed a decrease } \\
\text { in phenotypic } \\
\text { susceptibility but } \\
\text { no viral escape on } \\
\text { day } 9 \text { of GS-6207 } \\
\text { monotherapy. }\end{array}$ & [301] \\
\hline REBACIN $^{\circledR}$ & $\mathrm{HPV}$ & - & $\begin{array}{c}\text { Two } \\
\text { independent, } \\
\text { parallel RCTs: } \\
\text { Placebo (n: 39) vs. } \\
\text { REBACIN }^{\circledR} \text { (n: 40) } \\
\end{array}$ & - & $\begin{array}{c}\text { REBACIN }{ }^{\circledR} 0.5 \mathrm{~g} \text { per } \\
\text { dose, every other day } \\
\text { for } 3 \text { months except } \\
\text { during the menstrual } \\
\text { period }\end{array}$ & $\begin{array}{l}\text { HPV viral } \\
\text { clearance rate }\end{array}$ & $\begin{array}{c}\text { Viral clearance } \\
\text { rates: REBACIN } \\
61.5 \text { and } 62.5 \% \text { vs. } \\
\text { Placebo } 20.0 \text { and } \\
12.5 \% \\
\end{array}$ & [331] \\
\hline $\begin{array}{l}\text { NVR } \\
3-778\end{array}$ & $\mathrm{HBV}$ & $\begin{array}{c}\text { NCT02112799 } \\
\text { and } \\
\text { NCT02401737 }\end{array}$ & $\begin{array}{c}\text { Phase 1a in } \\
\text { NCT02112799 was } \\
\text { to evaluate the } \\
\text { safety of NVR3-778 } \\
\text { in health } \\
\text { volunteers. Phase } \\
\text { 1b RCTs of both } \\
\text { NCT02112799 and } \\
\text { NCT02401737 } \\
\text { focused on high } \\
\text { viremic chronic } \\
\text { HBV infected } \\
\text { patients. } \\
\text { Placebo (n:10) vs. } \\
\text { Treatment (n: 63) }\end{array}$ & $\begin{array}{l}\text { Phase } 1 \mathrm{a} \\
\text { and } 1 \mathrm{~b}\end{array}$ & 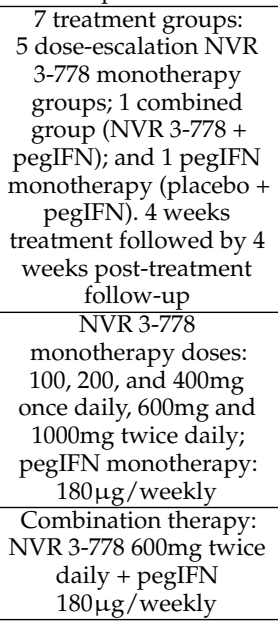 & $\begin{array}{l}\text { Adverse effect } \\
\text { assessment, } \\
\text { virology } \\
\text { assessment, drug } \\
\text { resistance } \\
\text { assessment, } \\
\text { pharmacokinetic } \\
\text { assessment. }\end{array}$ & $\begin{array}{l}\text { Patients treated } \\
\text { with more than } \\
\text { 1200mg daily NVR } \\
\text { 3-778 had lower } \\
\text { serum HBV RNA } \\
\text { and DNA. } \\
\text { Synergistic effect in } \\
\text { NVR 3-778 and } \\
\text { pegIFN exerted } \\
\text { strongest antiviral } \\
\text { efficacy. No } \\
\text { dose-related } \\
\text { adverse effects } \\
\text { reported. }\end{array}$ & [333] \\
\hline GLS4 & $\mathrm{HBV}$ & CTR20160068 & $\begin{array}{c}\text { Double-blind RCT: } \\
\text { Entecavir } \\
\text { (control) vs. GLS4 + } \\
\text { Ritonavir } \\
\text { (n:8 per group) }\end{array}$ & Phase 1b & $\begin{array}{c}\text { Control Entecavir } \\
\text { 0.5mg; GLS4 120mg + } \\
\text { Ritonavir 100mg; GLS4 } \\
\text { 240mg + Ritonavir } \\
\text { 100mg for } 28 \text { days } \\
\text { treatment }\end{array}$ & $\begin{array}{c}\begin{array}{c}\text { Adverse effect } \\
\text { assessment, } \\
\text { antiviral }\end{array} \\
\text { assessment, HBV } \\
\text { serum markers } \\
\text { assessment, and } \\
\text { drug resistant } \\
\text { assessment }\end{array}$ & $\begin{array}{c}\text { 120mg GLS4 was } \\
\text { well tolerated and } \\
\text { exerted antiviral } \\
\text { activity in } \\
\text { patients with } \\
\text { chronic HBV } \\
\text { infection }\end{array}$ & [334] \\
\hline
\end{tabular}




\section{Conclusions}

Viral proteins masquerade as host factors to exploit the host nuclear transport machinery for viral replication, and they reprogram the host cellular environment to enhance their replication and evade the host immunity. Nuclear transport inhibitors can not only interrupt viral replication but also disrupt the viral assembly and restore the host immunity. Targeting host factors to block nuclear transport could exert a broad-spectrum antiviral effect, as reported for Ivermectin. Nonetheless, the feasibility of using inhibitors of host factors as antiviral drugs could be limited when they target important NTRs, such as importin- $\beta 1$ and Crm1, owing to likely adverse effects. Furthermore, many infectious diseases, especially COVID-19, have a complicated clinical spectrum. The administration timing of the host-specific nuclear transport inhibitors needs to be carefully evaluated to maximize clinical benefits. In silico drug screening and in vitro and in vivo experiments could accelerate the identification of potent viral-specific nuclear transport inhibitors. As certain viral factors not only exploit the host NTRs but also have their own biological functions, viral-specific nuclear transport inhibitors could "kill two birds with one stone", that is, not only improve the viral clearance but also preserve/restore the host nucleocytoplasmic trafficking. Lastly, on the basis of our experience applying HS-AFM imaging to human NPCs [17,336], DNA-DNA-binding protein interactions [337], and viral proteins [338,339], we believe it will be worthwhile to observe the interaction between the viral factors and the host nuclear transport factors in real-time.

Author Contributions: Conceptualization, K.L.; writing, E.S.S. and K.L.; overview and supervision, R.W.W. All authors have read and agreed to the published version of the manuscript.

Funding: This project was funded by grants from the MEXT/JSPS KAKENHI (19K23841, 20K16262 (to K.L.), 17H05874, 17K08655 (to R.W.W.)) from MEXT Japan, the NanoLSI Grant for Transdisciplinary Research Promotion (to K.L.), Kanazawa University against COVID-19 (to R.W.W.), the Kobayashi International Scholarship Foundation (to R.W.W.), and the Shimadzu Science Foundation (to R.W.W.).

Acknowledgments: We thank all Wong Lab members for their kind assistance. We also thank reviewers for their efforts and the constructive comments in our review.

Conflicts of Interest: The authors declare no conflict of interest.

\section{References}

1. Korobeinikov, A. Immune response and within-host viral evolution: Immune response can accelerate evolution. J. Theor. Biol. 2018, 456, 74-83. [CrossRef] [PubMed]

2. Görlich, D.; Kutay, U. Transport between the cell nucleus and the cytoplasm. Ann. Rev. Cell Develop. Biol. 1999, 15, 607-660. [CrossRef]

3. Makhnevych, T.; Lusk, C.P.; Anderson, A.M.; Aitchison, J.D.; Wozniak, R.W. Cell cycle regulated transport controlled by alterations in the nuclear pore complex. Cell 2003, 115, 813-823. [CrossRef]

4. Nakano, H.; Funasaka, T.; Hashizume, C.; Wong, R.W. Nucleoporin translocated promoter region (Tpr) associates with dynein complex, preventing chromosome lagging formation during mitosis. J. Biol. Chem. 2010, 285, 10841-10849. [CrossRef]

5. Perera, R.M.; Stoykova, S.; Nicolay, B.N.; Ross, K.N.; Fitamant, J.; Boukhali, M.; Lengrand, J.; Deshpande, V.; Selig, M.K.; Ferrone, C.R.; et al. Transcriptional control of autophagy-lysosome function drives pancreatic cancer metabolism. Nature 2015, 524, 361-365. [CrossRef]

6. Dewi, F.R.P.; Jiapaer, S.; Kobayashi, A.; Hazawa, M.; Ikliptikawati, D.K.; Hartono; Sabit, H.; Nakada, M.; Wong, R.W. Nucleoporin TPR (translocated promoter region, nuclear basket protein) upregulation alters MTOR-HSF1 trails and suppresses autophagy induction in ependymoma. Autophagy 2021, 17, 1001-1012. [CrossRef]

7. Sun, J.; Shi, Y.; Yildirim, E. The nuclear pore complex in cell type-specific chromatin structure and gene regulation. Trends Genet. TIG 2019, 35, 579-588. [CrossRef] [PubMed]

8. Gu, Y.; Zebell, S.G.; Liang, Z.; Wang, S.; Kang, B.H.; Dong, X. Nuclear pore permeabilization is a convergent signaling event in effector-triggered immunity. Cell 2016, 166, 1526-1538. [CrossRef]

9. Lezon, T.R.; Sali, A.; Bahar, I. Global motions of the nuclear pore complex: Insights from elastic network models. PLoS Comput. Biol. 2009, 5, e1000496. [CrossRef] [PubMed]

10. Bui, K.H.; von Appen, A.; DiGuilio, A.L.; Ori, A.; Sparks, L.; Mackmull, M.T.; Bock, T.; Hagen, W.; Andrés-Pons, A.; Glavy, J.S.; et al. Integrated structural analysis of the human nuclear pore complex scaffold. Cell 2013, 155, 1233-1243. [CrossRef] 
11. Eibauer, M.; Pellanda, M.; Turgay, Y.; Dubrovsky, A.; Wild, A.; Medalia, O. Structure and gating of the nuclear pore complex. Nat. Commun. 2015, 6, 7532. [CrossRef]

12. Hülsmann, B.B.; Labokha, A.A.; Görlich, D. The permeability of reconstituted nuclear pores provides direct evidence for the selective phase model. Cell 2012, 150, 738-751. [CrossRef]

13. Lim, R.Y.; Huang, N.P.; Köser, J.; Deng, J.; Lau, K.H.; Schwarz-Herion, K.; Fahrenkrog, B.; Aebi, U. Flexible phenylalanine-glycine nucleoporins as entropic barriers to nucleocytoplasmic transport. Proc. Nat. Acad. Sci. USA 2006, 103, 9512-9517. [CrossRef]

14. Frey, S.; Görlich, D. A saturated FG-repeat hydrogel can reproduce the permeability properties of nuclear pore complexes. Cell 2007, 130, 512-523. [CrossRef] [PubMed]

15. Peters, R. Translocation through the nuclear pore complex: Selectivity and speed by reduction-of-dimensionality. Traffic 2005, 6 , 421-427. [CrossRef]

16. Patel, S.S.; Belmont, B.J.; Sante, J.M.; Rexach, M.F. Natively unfolded nucleoporins gate protein diffusion across the nuclear pore complex. Cell 2007, 129, 83-96. [CrossRef]

17. Mohamed, M.S.; Hazawa, M.; Kobayashi, A.; Guillaud, L.; Watanabe-Nakayama, T.; Nakayama, M.; Wang, H.; Kodera, N.; Oshima, M.; Ando, T.; et al. Spatiotemporally tracking of nano-biofilaments inside the nuclear pore complex core. Biomaterials 2020, 256, 120198. [CrossRef]

18. Dworetzky, S.I.; Lanford, R.E.; Feldherr, C.M. The effects of variations in the number and sequence of targeting signals on nuclear uptake. J. Cell Biol. 1988, 107, 1279-1287. [CrossRef]

19. Panté, N.; Kann, M. Nuclear pore complex is able to transport macromolecules with diameters of about $39 \mathrm{~nm}$. Mol. Biol. Cell 2002, 13, 425-434. [CrossRef] [PubMed]

20. Pumroy, R.A.; Cingolani, G. Diversification of importin- $\alpha$ isoforms in cellular trafficking and disease states. Biochem. J. 2015, 466, 13-28. [CrossRef] [PubMed]

21. Mosammaparast, N.; Pemberton, L.F. Karyopherins: From nuclear-transport mediators to nuclear-function regulators. Trends Cell Biol. 2004, 14, 547-556. [CrossRef]

22. Fontes, M.R.; Teh, T.; Kobe, B. Structural basis of recognition of monopartite and bipartite nuclear localization sequences by mammalian importin-alpha. J. Mol. Biol. 2000, 297, 1183-1194. [CrossRef] [PubMed]

23. Herold, A.; Truant, R.; Wiegand, H.; Cullen, B.R. Determination of the functional domain organization of the importin alpha nuclear import factor. J. Cell Biol. 1998, 143, 309-318. [CrossRef] [PubMed]

24. Conti, E.; Uy, M.; Leighton, L.; Blobel, G.; Kuriyan, J. Crystallographic analysis of the recognition of a nuclear localization signal by the nuclear import factor karyopherin alpha. Cell 1998, 94, 193-204. [CrossRef]

25. Kalderon, D.; Richardson, W.D.; Markham, A.F.; Smith, A.E. Sequence requirements for nuclear location of simian virus 40 large-T antigen. Nature 1984, 311, 33-38. [CrossRef]

26. Robbins, J.; Dilworth, S.M.; Laskey, R.A.; Dingwall, C. Two interdependent basic domains in nucleoplasmin nuclear targeting sequence: Identification of a class of bipartite nuclear targeting sequence. Cell 1991, 64, 615-623. [CrossRef]

27. Cingolani, G.; Petosa, C.; Weis, K.; Müller, C.W. Structure of importin-beta bound to the IBB domain of importin-alpha. Nature 1999, 399, 221-229. [CrossRef] [PubMed]

28. Bayliss, R.; Littlewood, T.; Stewart, M. Structural basis for the interaction between FxFG nucleoporin repeats and importin-beta in nuclear trafficking. Cell 2000, 102, 99-108. [CrossRef]

29. Conti, E.; Izaurralde, E. Nucleocytoplasmic transport enters the atomic age. Curr. Opin. Cell Biol. 2001, 13, 310-319. [CrossRef]

30. Lee, S.J.; Matsuura, Y.; Liu, S.M.; Stewart, M. Structural basis for nuclear import complex dissociation by RanGTP. Nature 2005, 435, 693-696. [CrossRef]

31. Görlich, D.; Panté, N.; Kutay, U.; Aebi, U.; Bischoff, F.R. Identification of different roles for RanGDP and RanGTP in nuclear protein import. EMBO J. 1996, 15, 5584-5594. [CrossRef]

32. Chi, N.C.; Adam, E.J.; Visser, G.D.; Adam, S.A. RanBP1 stabilizes the interaction of Ran with p97 nuclear protein import. J. Cell Biol. 1996, 135, 559-569. [CrossRef] [PubMed]

33. Rexach, M.; Blobel, G. Protein import into nuclei: Association and dissociation reactions involving transport substrate, transport factors, and nucleoporins. Cell 1995, 83, 683-692. [CrossRef]

34. Kutay, U.; Bischoff, F.R.; Kostka, S.; Kraft, R.; Görlich, D. Export of importin alpha from the nucleus is mediated by a specific nuclear transport factor. Cell 1997, 90, 1061-1071. [CrossRef]

35. Bischoff, F.R.; Klebe, C.; Kretschmer, J.; Wittinghofer, A.; Ponstingl, H. RanGAP1 induces GTPase activity of nuclear Ras-related Ran. Proc. Nat. Acad. Sci. USA 1994, 91, 2587-2591. [CrossRef]

36. Bischoff, F.R.; Krebber, H.; Kempf, T.; Hermes, I.; Ponstingl, H. Human RanGTPase-activating protein RanGAP1 is a homologue of yeast Rna1p involved in mRNA processing and transport. Proc. Nat. Acad. Sci. USA 1995, 92, 1749-1753. [CrossRef]

37. Bischoff, F.R.; Krebber, H.; Smirnova, E.; Dong, W.; Ponstingl, H. Co-activation of RanGTPase and inhibition of GTP dissociation by Ran-GTP binding protein RanBP1. EMBO J. 1995, 14, 705-715. [CrossRef]

38. Coutavas, E.; Ren, M.; Oppenheim, J.D.; D’Eustachio, P.; Rush, M.G. Characterization of proteins that interact with the cell-cycle regulatory protein Ran/TC4. Nature 1993, 366, 585-587. [CrossRef] [PubMed]

39. Bayliss, R.; Ribbeck, K.; Akin, D.; Kent, H.M.; Feldherr, C.M.; Görlich, D.; Stewart, M. Interaction between NTF2 and xFxFGcontaining nucleoporins is required to mediate nuclear import of RanGDP. J. Mol. Biol. 1999, 293, 579-593. [CrossRef] 
40. Bischoff, F.R.; Ponstingl, H. Catalysis of guanine nucleotide exchange on Ran by the mitotic regulator RCC1. Nature 1991, 354, 80-82. [CrossRef]

41. Fischer, U.; Huber, J.; Boelens, W.C.; Mattaj, I.W.; Lührmann, R. The HIV-1 Rev activation domain is a nuclear export signal that accesses an export pathway used by specific cellular RNAs. Cell 1995, 82, 475-483. [CrossRef]

42. Kırlı, K.; Karaca, S.; Dehne, H.J.; Samwer, M.; Pan, K.T.; Lenz, C.; Urlaub, H.; Görlich, D. A deep proteomics perspective on CRM1-mediated nuclear export and nucleocytoplasmic partitioning. eLife 2015, 4. [CrossRef]

43. Lindsay, M.E.; Holaska, J.M.; Welch, K.; Paschal, B.M.; Macara, I.G. Ran-binding protein 3 is a cofactor for Crm1-mediated nuclear protein export. J. Cell Biol. 2001, 153, 1391-1402. [CrossRef]

44. Hutten, S.; Kehlenbach, R.H. Nup214 is required for CRM1-dependent nuclear protein export in vivo. Mol. Cell. Biol. 2006, 26, 6772-6785. [CrossRef]

45. Li, Y.; Zhou, J.; Min, S.; Zhang, Y.; Zhang, Y.; Zhou, Q.; Shen, X.; Jia, D.; Han, J.; Sun, Q. Distinct RanBP1 nuclear export and cargo dissociation mechanisms between fungi and animals. eLife 2019, 8. [CrossRef]

46. Engelsma, D.; Bernad, R.; Calafat, J.; Fornerod, M. Supraphysiological nuclear export signals bind CRM1 independently of RanGTP and arrest at Nup358. EMBO J. 2004, 23, 3643-3652. [CrossRef] [PubMed]

47. Kehlenbach, R.H.; Dickmanns, A.; Kehlenbach, A.; Guan, T.; Gerace, L. A role for RanBP1 in the release of CRM1 from the nuclear pore complex in a terminal step of nuclear export. J. Cell Biol. 1999, 145, 645-657. [CrossRef]

48. Herold, A.; Suyama, M.; Rodrigues, J.P.; Braun, I.C.; Kutay, U.; Carmo-Fonseca, M.; Bork, P.; Izaurralde, E. TAP (NXF1) belongs to a multigene family of putative RNA export factors with a conserved modular architecture. Mol. Cell. Biol. 2000, 20, 8996-9008. [CrossRef] [PubMed]

49. Stage-Zimmermann, T.; Schmidt, U.; Silver, P.A. Factors affecting nuclear export of the 60 S ribosomal subunit in vivo. Mol. Biol. Cell 2000, 11, 3777-3789. [CrossRef] [PubMed]

50. Ohno, M.; Segref, A.; Bachi, A.; Wilm, M.; Mattaj, I.W. PHAX, a mediator of U snRNA nuclear export whose activity is regulated by phosphorylation. Cell 2000, 101, 187-198. [CrossRef]

51. Stade, K.; Ford, C.S.; Guthrie, C.; Weis, K. Exportin 1 (Crm1p) is an essential nuclear export factor. Cell 1997, 90, 1041-1050. [CrossRef]

52. Kutay, U.; Lipowsky, G.; Izaurralde, E.; Bischoff, F.R.; Schwarzmaier, P.; Hartmann, E.; Görlich, D. Identification of a tRNA-specific nuclear export receptor. Mol. Cell 1998, 1, 359-369. [CrossRef]

53. Arts, G.J.; Fornerod, M.; Mattaj, I.W. Identification of a nuclear export receptor for tRNA. Curr. Biol. CB 1998, 8, 305-314. [CrossRef]

54. Yi, R.; Qin, Y.; Macara, I.G.; Cullen, B.R. Exportin-5 mediates the nuclear export of pre-microRNAs and short hairpin RNAs. Genes Dev. 2003, 17, 3011-3016. [CrossRef] [PubMed]

55. Hautbergue, G.M.; Hung, M.L.; Golovanov, A.P.; Lian, L.Y.; Wilson, S.A. Mutually exclusive interactions drive handover of mRNA from export adaptors to TAP. Proc. Nat. Acad. Sci. USA 2008, 105, 5154-5159. [CrossRef]

56. Braun, I.C.; Herold, A.; Rode, M.; Izaurralde, E. Nuclear export of mRNA by TAP/NXF1 requires two nucleoporin-binding sites but not p15. Mol. Cell. Biol. 2002, 22, 5405-5418. [CrossRef] [PubMed]

57. Farny, N.G.; Hurt, J.A.; Silver, P.A. Definition of global and transcript-specific mRNA export pathways in metazoans. Genes Dev. 2008, 22, 66-78. [CrossRef]

58. Guzik, B.W.; Levesque, L.; Prasad, S.; Bor, Y.C.; Black, B.E.; Paschal, B.M.; Rekosh, D.; Hammarskjöld, M.L. NXT1 (p15) is a crucial cellular cofactor in TAP-dependent export of intron-containing RNA in mammalian cells. Mol. Cell. Biol. 2001, 21, $2545-2554$. [CrossRef]

59. Grüter, P.; Tabernero, C.; von Kobbe, C.; Schmitt, C.; Saavedra, C.; Bachi, A.; Wilm, M.; Felber, B.K.; Izaurralde, E. TAP, the human homolog of Mex67p, mediates CTE-dependent RNA export from the nucleus. Mol. Cell 1998, 1, 649-659. [CrossRef]

60. Blevins, M.B.; Smith, A.M.; Phillips, E.M.; Powers, M.A. Complex formation among the RNA export proteins Nup98, Rae1/Gle2, and TAP. J. Biol. Chem. 2003, 278, 20979-20988. [CrossRef]

61. Fribourg, S.; Braun, I.C.; Izaurralde, E.; Conti, E. Structural basis for the recognition of a nucleoporin FG repeat by the NTF2-like domain of the TAP/p15 mRNA nuclear export factor. Mol. Cell 2001, 8, 645-656. [CrossRef]

62. Braun, I.C.; Rohrbach, E.; Schmitt, C.; Izaurralde, E. TAP binds to the constitutive transport element (CTE) through a novel RNA-binding motif that is sufficient to promote CTE-dependent RNA export from the nucleus. EMBO J. 1999, 18, $1953-1965$. [CrossRef] [PubMed]

63. Xie, Y.; Ren, Y. Mechanisms of nuclear mRNA export: A structural perspective. Traffic 2019, 20, 829-840. [CrossRef]

64. Brennan, C.M.; Gallouzi, I.E.; Steitz, J.A. Protein ligands to HuR modulate its interaction with target mRNAs in vivo. J. Cell Biol. 2000, 151, 1-14. [CrossRef] [PubMed]

65. Yang, J.; Bogerd, H.P.; Wang, P.J.; Page, D.C.; Cullen, B.R. Two closely related human nuclear export factors utilize entirely distinct export pathways. Mol. Cell 2001, 8, 397-406. [CrossRef]

66. Volpon, L.; Culjkovic-Kraljacic, B.; Sohn, H.S.; Blanchet-Cohen, A.; Osborne, M.J.; Borden, K.L.B. A biochemical framework for eIF4E-dependent mRNA export and nuclear recycling of the export machinery. RNA 2017, 23, 927-937. [CrossRef] [PubMed]

67. Trotta, C.R.; Lund, E.; Kahan, L.; Johnson, A.W.; Dahlberg, J.E. Coordinated nuclear export of 60S ribosomal subunits and NMD3 in vertebrates. EMBO J. 2003, 22, 2841-2851. [CrossRef] 
68. Fehr, A.R.; Perlman, S. Coronaviruses: An overview of their replication and pathogenesis. Methods Mol. Biol. 2015, 1282, 1-23. [CrossRef] [PubMed]

69. Weiss, S.R.; Navas-Martin, S. Coronavirus pathogenesis and the emerging pathogen severe acute respiratory syndrome coronavirus. Microbiol. Mol. Biol. Rev. MMBR 2005, 69, 635-664. [CrossRef]

70. Bleibtreu, A.; Bertine, M.; Bertin, C.; Houhou-Fidouh, N.; Visseaux, B. Focus on Middle East respiratory syndrome coronavirus (MERS-CoV). Med. Mal. Infect. 2020, 50, 243-251. [CrossRef]

71. Zhu, N.; Zhang, D.; Wang, W.; Li, X.; Yang, B.; Song, J.; Zhao, X.; Huang, B.; Shi, W.; Lu, R.; et al. A Novel Coronavirus from Patients with Pneumonia in China, 2019. N. Eng. J. Med. 2020, 382, 727-733. [CrossRef] [PubMed]

72. Snijder, E.J.; Limpens, R.; de Wilde, A.H.; de Jong, A.W.M.; Zevenhoven-Dobbe, J.C.; Maier, H.J.; Faas, F.; Koster, A.J.; Bárcena, M. A unifying structural and functional model of the coronavirus replication organelle: Tracking down RNA synthesis. PLoS Biol. 2020, 18, e3000715. [CrossRef]

73. Wolff, G.; Limpens, R.; Zevenhoven-Dobbe, J.C.; Laugks, U.; Zheng, S.; de Jong, A.W.M.; Koning, R.I.; Agard, D.A.; Grünewald, K.; Koster, A.J.; et al. A molecular pore spans the double membrane of the coronavirus replication organelle. Science 2020, 369, 1395-1398. [CrossRef]

74. Gordon, D.E.; Jang, G.M.; Bouhaddou, M.; Xu, J.; Obernier, K.; White, K.M.; O’Meara, M.J.; Rezelj, V.V.; Guo, J.Z.; Swaney, D.L.; et al. A SARS-CoV-2 protein interaction map reveals targets for drug repurposing. Nature 2020, 583, 459-468. [CrossRef] [PubMed]

75. Miorin, L.; Kehrer, T.; Sanchez-Aparicio, M.T.; Zhang, K.; Cohen, P.; Patel, R.S.; Cupic, A.; Makio, T.; Mei, M.; Moreno, E.; et al. SARS-CoV-2 Orf6 hijacks Nup98 to block STAT nuclear import and antagonize interferon signaling. Proc. Nat. Acad. Sci. USA 2020, 117, 28344-28354. [CrossRef]

76. Kato, K.; Ikliptikawati, D.K.; Kobayashi, A.; Kondo, H.; Lim, K.; Hazawa, M.; Wong, R.W. Overexpression of SARS-CoV-2 protein ORF6 dislocates RAE1 and NUP98 from the nuclear pore complex. Biochem. Biophys. Res. Commun. 2021, 536, 59-66. [CrossRef]

77. Addetia, A.; Lieberman, N.A.P.; Phung, Q.; Hsiang, T.Y.; Xie, H.; Roychoudhury, P.; Shrestha, L.; Loprieno, M.A.; Huang, M.L.; Gale, M., Jr.; et al. SARS-CoV-2 ORF6 Disrupts Bidirectional Nucleocytoplasmic Transport through Interactions with Rae1 and Nup98. mBio 2021, 12. [CrossRef]

78. Xia, H.; Cao, Z.; Xie, X.; Zhang, X.; Chen, J.Y.; Wang, H.; Menachery, V.D.; Rajsbaum, R.; Shi, P.Y. Evasion of Type I Interferon by SARS-CoV-2. Cell Rep. 2020, 33, 108234. [CrossRef]

79. Frieman, M.; Yount, B.; Heise, M.; Kopecky-Bromberg, S.A.; Palese, P.; Baric, R.S. Severe acute respiratory syndrome coronavirus ORF6 antagonizes STAT1 function by sequestering nuclear import factors on the rough endoplasmic reticulum/Golgi membrane J. Virol. 2007, 81, 9812-9824. [CrossRef]

80. Kopecky-Bromberg, S.A.; Martínez-Sobrido, L.; Frieman, M.; Baric, R.A.; Palese, P. Severe acute respiratory syndrome coronavirus open reading frame (ORF) 3b, ORF 6, and nucleocapsid proteins function as interferon antagonists. J. Virol. 2007, 81, 548-557. [CrossRef] [PubMed]

81. Izaurralde, E.; Jarmolowski, A.; Beisel, C.; Mattaj, I.W.; Dreyfuss, G.; Fischer, U. A role for the M9 transport signal of hnRNP A1 in mRNA nuclear export. J. Cell Biol. 1997, 137, 27-35. [CrossRef] [PubMed]

82. Roy, R.; Durie, D.; Li, H.; Liu, B.Q.; Skehel, J.M.; Mauri, F.; Cuorvo, L.V.; Barbareschi, M.; Guo, L.; Holcik, M.; et al. hnRNPA1 couples nuclear export and translation of specific mRNAs downstream of FGF-2/S6K2 signalling. Nucl. Acids Res. 2014, 42, 12483-12497. [CrossRef] [PubMed]

83. Zhang, K.; Miorin, L.; Makio, T.; Dehghan, I.; Gao, S.; Xie, Y.; Zhong, H.; Esparza, M.; Kehrer, T.; Kumar, A.; et al. Nsp1 protein of SARS-CoV-2 disrupts the mRNA export machinery to inhibit host gene expression. Sci. Adv. 2021, 7. [CrossRef]

84. Gomez, G.N.; Abrar, F.; Dodhia, M.P.; Gonzalez, F.G.; Nag, A. SARS coronavirus protein nsp1 disrupts localization of Nup93 from the nuclear pore complex. Biochem. Cell Biol. Biochim. Biol. Cell. 2019, 97, 758-766. [CrossRef]

85. Sharma, K.; Åkerström, S.; Sharma, A.K.; Chow, V.T.; Teow, S.; Abrenica, B.; Booth, S.A.; Booth, T.F.; Mirazimi, A.; Lal, S.K. SARS-CoV $9 \mathrm{~b}$ protein diffuses into nucleus, undergoes active $\mathrm{Crm} 1$ mediated nucleocytoplasmic export and triggers apoptosis when retained in the nucleus. PLOS ONE 2011, 6, e19436. [CrossRef]

86. Yang, Y.; Ye, F.; Zhu, N.; Wang, W.; Deng, Y.; Zhao, Z.; Tan, W. Middle East respiratory syndrome coronavirus ORF4b protein inhibits type I interferon production through both cytoplasmic and nuclear targets. Sci. Rep. 2015, 5, 17554. [CrossRef] [PubMed]

87. Canton, J.; Fehr, A.R.; Fernandez-Delgado, R.; Gutierrez-Alvarez, F.J.; Sanchez-Aparicio, M.T.; García-Sastre, A.; Perlman, S.; Enjuanes, L.; Sola, I. MERS-CoV $4 b$ protein interferes with the NF- $\mathrm{kB}$-dependent innate immune response during infection. PLoS Pathog. 2018, 14, e1006838. [CrossRef]

88. Schmidt, M.L.; Hoenen, T. Characterization of the catalytic center of the Ebola virus L polymerase. PLoS Negl. Trop. Dis. 2017, 11, e0005996. [CrossRef]

89. Bodmer, B.S.; Greßler, J.; Schmidt, M.L.; Holzerland, J.; Brandt, J.; Braun, S.; Groseth, A.; Hoenen, T. Differences in Viral RNA Synthesis but Not Budding or Entry Contribute to the In Vitro Attenuation of Reston Virus Compared to Ebola Virus. Microorganisms 2020, 8, 1215. [CrossRef]

90. Reid, S.P.; Valmas, C.; Martinez, O.; Sanchez, F.M.; Basler, C.F. Ebola virus VP24 proteins inhibit the interaction of NPI-1 subfamily karyopherin alpha proteins with activated STAT1. J. Virol. 2007, 81, 13469-13477. [CrossRef]

91. Reid, S.P.; Leung, L.W.; Hartman, A.L.; Martinez, O.; Shaw, M.L.; Carbonnelle, C.; Volchkov, V.E.; Nichol, S.T.; Basler, C.F. Ebola virus VP24 binds karyopherin alpha1 and blocks STAT1 nuclear accumulation. J. Virol. 2006, 80, 5156-5167. [CrossRef] 
92. Xu, W.; Edwards, M.R.; Borek, D.M.; Feagins, A.R.; Mittal, A.; Alinger, J.B.; Berry, K.N.; Yen, B.; Hamilton, J.; Brett, T.J.; et al. Ebola virus VP24 targets a unique NLS binding site on karyopherin alpha 5 to selectively compete with nuclear import of phosphorylated STAT1. Cell Host Microbe 2014, 16, 187-200. [CrossRef]

93. He, F.; Melén, K.; Maljanen, S.; Lundberg, R.; Jiang, M.; Österlund, P.; Kakkola, L.; Julkunen, I. Ebolavirus protein VP24 interferes with innate immune responses by inhibiting interferon- $\lambda 1$ gene expression. Virology 2017, 509, 23-34. [CrossRef]

94. Zhang, A.P.; Bornholdt, Z.A.; Liu, T.; Abelson, D.M.; Lee, D.E.; Li, S.; Woods, V.L., Jr.; Saphire, E.O. The ebola virus interferon antagonist VP24 directly binds STAT1 and has a novel, pyramidal fold. PLoS Pathog. 2012, 8, e1002550. [CrossRef]

95. Marg, A.; Shan, Y.; Meyer, T.; Meissner, T.; Brandenburg, M.; Vinkemeier, U. Nucleocytoplasmic shuttling by nucleoporins Nup153 and Nup214 and CRM1-dependent nuclear export control the subcellular distribution of latent Stat1. J. Cell Biol. 2004, 165, 823-833. [CrossRef] [PubMed]

96. Chatterjee-Kishore, M.; Wright, K.L.; Ting, J.P.; Stark, G.R. How Stat1 mediates constitutive gene expression: A complex of unphosphorylated Stat1 and IRF1 supports transcription of the LMP2 gene. EMBO J. 2000, 19, 4111-4122. [CrossRef]

97. Shabman, R.S.; Gulcicek, E.E.; Stone, K.L.; Basler, C.F. The Ebola virus VP24 protein prevents hnRNP C1/C2 binding to karyopherin $\alpha 1$ and partially alters its nuclear import. J. Infect. Dis. 2011, 204, S904-S910. [CrossRef] [PubMed]

98. Kim, J.H.; Paek, K.Y.; Choi, K.; Kim, T.D.; Hahm, B.; Kim, K.T.; Jang, S.K. Heterogeneous nuclear ribonucleoprotein C modulates translation of c-myc mRNA in a cell cycle phase-dependent manner. Mol. Cell. Biol. 2003, 23, 708-720. [CrossRef] [PubMed]

99. Pfeifer, I.; Elsby, R.; Fernandez, M.; Faria, P.A.; Nussenzveig, D.R.; Lossos, I.S.; Fontoura, B.M.; Martin, W.D.; Barber, G.N. NFAR-1 and -2 modulate translation and are required for efficient host defense. Proc. Nat. Acad. Sci. USA 2008, 105, 4173-4178. [CrossRef]

100. Brunner, J.E.; Nguyen, J.H.; Roehl, H.H.; Ho, T.V.; Swiderek, K.M.; Semler, B.L. Functional interaction of heterogeneous nuclear ribonucleoprotein $\mathrm{C}$ with poliovirus RNA synthesis initiation complexes. J. Virol. 2005, 79, 3254-3266. [CrossRef]

101. Gontarek, R.R.; Gutshall, L.L.; Herold, K.M.; Tsai, J.; Sathe, G.M.; Mao, J.; Prescott, C.; Del Vecchio, A.M. hnRNP C and polypyrimidine tract-binding protein specifically interact with the pyrimidine-rich region within the $3^{\prime}$ NTR of the HCV RNA genome. Nucl. Acids Res. 1999, 27, 1457-1463. [CrossRef] [PubMed]

102. Sokolowski, M.; Schwartz, S. Heterogeneous nuclear ribonucleoprotein C binds exclusively to the functionally important UUUUU-motifs in the human papillomavirus type-1 AU-rich inhibitory element. Virus Res. 2001, 73, 163-175. [CrossRef]

103. Miyake, T.; Farley, C.M.; Neubauer, B.E.; Beddow, T.P.; Hoenen, T.; Engel, D.A. ebola virus inclusion body formation and RNA synthesis are controlled by a novel domain of nucleoprotein interacting with VP35. J. Virol. 2020, 94. [CrossRef]

104. Gabriel, G.; Feldmann, F.; Reimer, R.; Thiele, S.; Fischer, M.; Hartmann, E.; Bader, M.; Ebihara, H.; Hoenen, T.; Feldmann, H. Importin- $\alpha 7$ Is Involved in the Formation of Ebola Virus Inclusion Bodies but Is Not Essential for Pathogenicity in Mice. J. Infect. Dis. 2015, 212, S316-S321. [CrossRef]

105. Wendt, L.; Brandt, J.; Bodmer, B.S.; Reiche, S.; Schmidt, M.L.; Traeger, S.; Hoenen, T. The ebola virus nucleoprotein recruits the nuclear RNA Export Factor NXF1 into inclusion bodies to facilitate viral protein expression. Cells 2020, 9, 187. [CrossRef] [PubMed]

106. Hertzog, J.; Dias Junior, A.G.; Rigby, R.E.; Donald, C.L.; Mayer, A.; Sezgin, E.; Song, C.; Jin, B.; Hublitz, P.; Eggeling, C.; et al. Infection with a Brazilian isolate of Zika virus generates RIG-I stimulatory RNA and the viral NS5 protein blocks type I IFN induction and signaling. Eur. J. Immunol. 2018, 48, 1120-1136. [CrossRef] [PubMed]

107. Gillespie, L.K.; Hoenen, A.; Morgan, G.; Mackenzie, J.M. The endoplasmic reticulum provides the membrane platform for biogenesis of the flavivirus replication complex. J. Virol. 2010, 84, 10438-10447. [CrossRef] [PubMed]

108. Welsch, S.; Miller, S.; Romero-Brey, I.; Merz, A.; Bleck, C.K.; Walther, P.; Fuller, S.D.; Antony, C.; Krijnse-Locker, J.; Bartenschlager, R. Composition and three-dimensional architecture of the dengue virus replication and assembly sites. Cell Host Microbe 2009, 5, 365-375. [CrossRef]

109. Yu, L.; Takeda, K.; Markoff, L. Protein-protein interactions among West Nile non-structural proteins and transmembrane complex formation in mammalian cells. Virology 2013, 446, 365-377. [CrossRef]

110. Ashour, J.; Laurent-Rolle, M.; Shi, P.Y.; García-Sastre, A. NS5 of dengue virus mediates STAT2 binding and degradation. J. Virol. 2009, 83, 5408-5418. [CrossRef]

111. Brooks, A.J.; Johansson, M.; John, A.V.; Xu, Y.; Jans, D.A.; Vasudevan, S.G. The interdomain region of dengue NS5 protein that binds to the viral helicase NS3 contains independently functional importin beta 1 and importin alpha/beta-recognized nuclear localization signals. J. Biol. Chem. 2002, 277, 36399-36407. [CrossRef]

112. Pryor, M.J.; Rawlinson, S.M.; Butcher, R.E.; Barton, C.L.; Waterhouse, T.A.; Vasudevan, S.G.; Bardin, P.G.; Wright, P.J.; Jans, D.A.; Davidson, A.D. Nuclear localization of dengue virus nonstructural protein 5 through its importin alpha/beta-recognized nuclear localization sequences is integral to viral infection. Traffic 2007, 8, 795-807. [CrossRef]

113. Potisopon, S.; Priet, S.; Collet, A.; Decroly, E.; Canard, B.; Selisko, B. The methyltransferase domain of dengue virus protein NS5 ensures efficient RNA synthesis initiation and elongation by the polymerase domain. Nucl. Acids Res. 2014, 42, 11642-11656. [CrossRef]

114. Hannemann, H.; Sung, P.Y.; Chiu, H.C.; Yousuf, A.; Bird, J.; Lim, S.P.; Davidson, A.D. Serotype-specific differences in dengue virus non-structural protein 5 nuclear localization. J. Biol. Chem. 2013, 288, 22621-22635. [CrossRef]

115. Tay, M.Y.; Smith, K.; Ng, I.H.; Chan, K.W.; Zhao, Y.; Ooi, E.E.; Lescar, J.; Luo, D.; Jans, D.A.; Forwood, J.K.; et al. The C-terminal 18 Amino Acid Region of Dengue Virus NS5 Regulates its Subcellular Localization and Contains a Conserved Arginine Residue Essential for Infectious Virus Production. PLoS Pathog. 2016, 12, e1005886. [CrossRef] 
116. Rawlinson, S.M.; Pryor, M.J.; Wright, P.J.; Jans, D.A. CRM1-mediated nuclear export of dengue virus RNA polymerase NS5 modulates interleukin-8 induction and virus production. J. Biol. Chem. 2009, 284, 15589-15597. [CrossRef]

117. De Jesús-González, L.A.; Cervantes-Salazar, M.; Reyes-Ruiz, J.M.; Osuna-Ramos, J.F.; Farfán-Morales, C.N.; Palacios-Rápalo, S.N.; Pérez-Olais, J.H.; Cordero-Rivera, C.D.; Hurtado-Monzón, A.M.; Ruíz-Jiménez, F.; et al. The nuclear pore complex: A Target for NS3 protease of dengue and zika viruses. Viruses 2020, 12, 583. [CrossRef] [PubMed]

118. Palacios-Rápalo, S.N.; De Jesús-González, L.A.; Reyes-Ruiz, J.M.; Osuna-Ramos, J.F.; Farfan-Morales, C.N.; Gutiérrez-Escolano, A.L.; Del Ángel, R.M. Nuclear localization of non-structural protein 3 (NS3) during dengue virus infection. Arch. Virol. 2021, 166, 1439-1446. [CrossRef] [PubMed]

119. Gulland, A. Zika virus is a global public health emergency, declares WHO. BMJ 2016, 352, i657. [CrossRef] [PubMed]

120. Kleber de Oliveira, W.; Cortez-Escalante, J.; De Oliveira, W.T.; do Carmo, G.M.; Henriques, C.M.; Coelho, G.E.; Araújo de França, G.V. Increase in reported prevalence of microcephaly in infants born to women living in areas with confirmed zika virus transmission during the first trimester of pregnancy-brazil, 2015. MMWR Morb. Mortal. Wkly. Rep. 2016, 65, 242-247. [CrossRef]

121. Yang, L.; Wang, R.; Yang, S.; Ma, Z.; Lin, S.; Nan, Y.; Li, Q.; Tang, Q.; Zhang, Y.J. Karyopherin alpha 6 is required for replication of porcine reproductive and respiratory syndrome virus and zika virus. J. Virol. 2018, 92. [CrossRef] [PubMed]

122. Ji, W.; Luo, G. Zika virus NS5 nuclear accumulation is protective of protein degradation and is required for viral RNA replication. Virology 2020, 541, 124-135. [CrossRef] [PubMed]

123. Ng, I.H.W.; Chan, K.W.; Tan, M.J.A.; Gwee, C.P.; Smith, K.M.; Jeffress, S.J.; Saw, W.G.; Swarbrick, C.M.D.; Watanabe, S.; Jans, D.A.; et al. Zika Virus NS5 forms supramolecular nuclear bodies that sequester importin- $\alpha$ and modulate the host immune and pro-inflammatory response in neuronal cells. ACS Infect. Dis. 2019, 5, 932-948. [CrossRef]

124. Ye, J.; Chen, Z.; Li, Y.; Zhao, Z.; He, W.; Zohaib, A.; Song, Y.; Deng, C.; Zhang, B.; Chen, H.; et al. Japanese encephalitis virus NS5 Inhibits Type I Interferon (IFN) production by blocking the nuclear translocation of ifn regulatory factor 3 and NF- $\mathrm{B}$. J. Virol. 2017, 91. [CrossRef]

125. Lin, S.; Yang, S.; He, J.; Guest, J.D.; Ma, Z.; Yang, L.; Pierce, B.G.; Tang, Q.; Zhang, Y.J. Zika virus NS5 protein antagonizes type I interferon production via blocking TBK1 activation. Virology 2019, 527, 180-187. [CrossRef] [PubMed]

126. He, J.; Yang, L.; Chang, P.; Yang, S.; Lin, S.; Tang, Q.; Wang, X.; Zhang, Y.J. Zika virus NS2A protein induces the degradation of KPNA2 (karyopherin subunit alpha 2) via chaperone-mediated autophagy. Autophagy 2020, 16, 2238-2251. [CrossRef]

127. Remenyi, R.; Gao, Y.; Hughes, R.E.; Curd, A.; Zothner, C.; Peckham, M.; Merits, A.; Harris, M. Persistent replication of a chikungunya virus replicon in human cells is associated with presence of stable cytoplasmic granules containing nonstructural protein 3. J. Virol. 2018, 92. [CrossRef] [PubMed]

128. Hawman, D.W.; Stoermer, K.A.; Montgomery, S.A.; Pal, P.; Oko, L.; Diamond, M.S.; Morrison, T.E. Chronic joint disease caused by persistent Chikungunya virus infection is controlled by the adaptive immune response. J. Virol. 2013, 87, 13878-13888. [CrossRef]

129. Thomas, S.; Rai, J.; John, L.; Schaefer, S.; Pützer, B.M.; Herchenröder, O. Chikungunya virus capsid protein contains nuclear import and export signals. Virol. J. 2013, 10, 269. [CrossRef]

130. Jacobs, S.C.; Taylor, A.; Herrero, L.J.; Mahalingam, S.; Fazakerley, J.K. Mutation of a conserved nuclear export sequence in chikungunya virus capsid protein disrupts host cell nuclear import. Viruses 2017, 9, 306. [CrossRef]

131. Webb, L.G.; Veloz, J.; Pintado-Silva, J.; Zhu, T.; Rangel, M.V.; Mutetwa, T.; Zhang, L.; Bernal-Rubio, D.; Figueroa, D.; Carrau, L.; et al. Chikungunya virus antagonizes cGAS-STING mediated type-I interferon responses by degrading cGAS. PLoS Pathog. 2020, 16, e1008999. [CrossRef]

132. Göertz, G.P.; McNally, K.L.; Robertson, S.J.; Best, S.M.; Pijlman, G.P.; Fros, J.J. The methyltransferase-like domain of chikungunya virus nsP2 inhibits the interferon response by promoting the nuclear export of STAT1. J. Virol. 2018, 92. [CrossRef]

133. Fros, J.J.; Liu, W.J.; Prow, N.A.; Geertsema, C.; Ligtenberg, M.; Vanlandingham, D.L.; Schnettler, E.; Vlak, J.M.; Suhrbier, A.; Khromykh, A.A.; et al. Chikungunya virus nonstructural protein 2 inhibits type I/II interferon-stimulated JAK-STAT signaling. J. Virol. 2010, 84, 10877-10887. [CrossRef] [PubMed]

134. Fros, J.J.; van der Maten, E.; Vlak, J.M.; Pijlman, G.P. The C-terminal domain of chikungunya virus nsP2 independently governs viral RNA replication, cytopathicity, and inhibition of interferon signaling. J. Virol. 2013, 87, 10394-10400. [CrossRef]

135. Wong, K.Z.; Chu, J.J.H. The interplay of viral and host factors in chikungunya virus infection: Targets for antiviral strategies. Viruses 2018, 10, 294. [CrossRef]

136. Fros, J.J.; Major, L.D.; Scholte, F.E.M.; Gardner, J.; van Hemert, M.J.; Suhrbier, A.; Pijlman, G.P. Chikungunya virus non-structural protein 2-mediated host shut-off disables the unfolded protein response. J. Gen. Virol. 2015, 96, 580-589. [CrossRef] [PubMed]

137. Poiesz, B.J.; Ruscetti, F.W.; Gazdar, A.F.; Bunn, P.A.; Minna, J.D.; Gallo, R.C. Detection and isolation of type C retrovirus particles from fresh and cultured lymphocytes of a patient with cutaneous T-cell lymphoma. Proc. Nat. Acad. Sci. USA 1980, 77, 7415-7419. [CrossRef]

138. Barré-Sinoussi, F.; Chermann, J.C.; Rey, F.; Nugeyre, M.T.; Chamaret, S.; Gruest, J.; Dauguet, C.; Axler-Blin, C.; Vézinet-Brun, F.; Rouzioux, C.; et al. Isolation of a T-lymphotropic retrovirus from a patient at risk for acquired immune deficiency syndrome (AIDS). Science 1983, 220, 868-871. [CrossRef] [PubMed]

139. Engelman, A.N.; Singh, P.K. Cellular and molecular mechanisms of HIV-1 integration targeting. Cell. Mol. Life Sci. 2018, 75, 2491-2507. [CrossRef]

140. Wong, R.W.; Mamede, J.I.; Hope, T.J. Impact of nucleoporin-mediated chromatin localization and nuclear architecture on HIV integration site selection. J. Virol. 2015, 89, 9702-9705. [CrossRef] 
141. Popov, S.; Rexach, M.; Ratner, L.; Blobel, G.; Bukrinsky, M. Viral protein R regulates docking of the HIV-1 preintegration complex to the nuclear pore complex. J. Biol. Chem. 1998, 273, 13347-13352. [CrossRef] [PubMed]

142. Zhou, H.; Xu, M.; Huang, Q.; Gates, A.T.; Zhang, X.D.; Castle, J.C.; Stec, E.; Ferrer, M.; Strulovici, B.; Hazuda, D.J.; et al. Genome-scale RNAi screen for host factors required for HIV replication. Cell Host Microbe 2008, 4, 495-504. [CrossRef]

143. König, R.; Zhou, Y.; Elleder, D.; Diamond, T.L.; Bonamy, G.M.; Irelan, J.T.; Chiang, C.Y.; Tu, B.P.; De Jesus, P.D.; Lilley, C.E.; et al. Global analysis of host-pathogen interactions that regulate early-stage HIV-1 replication. Cell 2008, 135, 49-60. [CrossRef]

144. Brass, A.L.; Dykxhoorn, D.M.; Benita, Y.; Yan, N.; Engelman, A.; Xavier, R.J.; Lieberman, J.; Elledge, S.J. Identification of host proteins required for HIV infection through a functional genomic screen. Science 2008, 319, 921-926. [CrossRef]

145. Imbeault, M.; Ouellet, M.; Tremblay, M.J. Microarray study reveals that HIV-1 induces rapid type-I interferon-dependent p53 mRNA up-regulation in human primary CD4+ T cells. Retrovirology 2009, 6, 5. [CrossRef]

146. Tsurutani, N.; Kubo, M.; Maeda, Y.; Ohashi, T.; Yamamoto, N.; Kannagi, M.; Masuda, T. Identification of critical amino acid residues in human immunodeficiency virus type $1 \mathrm{IN}$ required for efficient proviral DNA formation at steps prior to integration in dividing and nondividing cells. J. Virol. 2000, 74, 4795-4806. [CrossRef] [PubMed]

147. Gallay, P.; Stitt, V.; Mundy, C.; Oettinger, M.; Trono, D. Role of the karyopherin pathway in human immunodeficiency virus type 1 nuclear import. J. Virol. 1996, 70, 1027-1032. [CrossRef] [PubMed]

148. Fouchier, R.A.; Meyer, B.E.; Simon, J.H.; Fischer, U.; Malim, M.H. HIV-1 infection of non-dividing cells: Evidence that the amino-terminal basic region of the viral matrix protein is important for Gag processing but not for post-entry nuclear import. EMBO J. 1997, 16, 4531-4539. [CrossRef]

149. Ganser-Pornillos, B.K.; Cheng, A.; Yeager, M. Structure of full-length HIV-1 CA: A model for the mature capsid lattice. Cell 2007, 131, 70-79. [CrossRef] [PubMed]

150. Arhel, N.J.; Souquere-Besse, S.; Munier, S.; Souque, P.; Guadagnini, S.; Rutherford, S.; Prévost, M.C.; Allen, T.D.; Charneau, P. HIV-1 DNA Flap formation promotes uncoating of the pre-integration complex at the nuclear pore. EMBO J. 2007, 26, 3025-3037. [CrossRef]

151. Li, C.; Burdick, R.C.; Nagashima, K.; Hu, W.S.; Pathak, V.K. HIV-1 cores retain their integrity until minutes before uncoating in the nucleus. Proc. Nat. Acad. Sci. USA 2021, 118, e2019467118. [CrossRef]

152. Francis, A.C.; Marin, M.; Prellberg, M.J.; Palermino-Rowland, K.; Melikyan, G.B. HIV-1 Uncoating and Nuclear Import Precede the Completion of Reverse Transcription in Cell Lines and in Primary Macrophages. Viruses 2020, 12, 1234. [CrossRef]

153. Dharan, A.; Bachmann, N.; Talley, S.; Zwikelmaier, V.; Campbell, E.M. Nuclear pore blockade reveals that HIV-1 completes reverse transcription and uncoating in the nucleus. Nat. Microbiol. 2020, 5, 1088-1095. [CrossRef]

154. Zila, V.; Margiotta, E.; Turoňová, B.; Müller, T.G.; Zimmerli, C.E.; Mattei, S.; Allegretti, M.; Börner, K.; Rada, J.; Müller, B.; et al. Cone-shaped HIV-1 capsids are transported through intact nuclear pores. Cell 2021, 184, 1032-1046.e18. [CrossRef] [PubMed]

155. Khan, H.; Sumner, R.P.; Rasaiyaah, J.; Tan, C.P.; Rodriguez-Plata, M.T.; Van Tulleken, C.; Fink, D.; Zuliani-Alvarez, L.; Thorne, L.; Stirling, D.; et al. HIV-1 Vpr antagonizes innate immune activation by targeting karyopherin-mediated NF- $\mathrm{KB} / \mathrm{IRF} 3$ nuclear transport. eLife 2020, 9, e60821. [CrossRef]

156. Karni, O.; Friedler, A.; Zakai, N.; Gilon, C.; Loyter, A. A peptide derived from the N-terminal region of HIV-1 Vpr promotes nuclear import in permeabilized cells: Elucidation of the NLS region of the Vpr. FEBS Lett. 1998, 429, 421-425. [CrossRef]

157. Nitahara-Kasahara, Y.; Kamata, M.; Yamamoto, T.; Zhang, X.; Miyamoto, Y.; Muneta, K.; Iijima, S.; Yoneda, Y.; Tsunetsugu-Yokota, Y.; Aida, Y. Novel nuclear import of Vpr promoted by importin alpha is crucial for human immunodeficiency virus type 1 replication in macrophages. J. Virol. 2007, 81, 5284-5293. [CrossRef] [PubMed]

158. Miyatake, H.; Sanjoh, A.; Murakami, T.; Murakami, H.; Matsuda, G.; Hagiwara, K.; Yokoyama, M.; Sato, H.; Miyamoto, Y.; Dohmae, N.; et al. Molecular Mechanism of HIV-1 Vpr for Binding to Importin- $\alpha$. J. Mol. Biol. 2016, 428, 2744-2757. [CrossRef]

159. Pollard, V.W.; Malim, M.H. The HIV-1 Rev protein. Ann. Rev. Microbiol. 1998, 52, 491-532. [CrossRef] [PubMed]

160. Henderson, B.R.; Percipalle, P. Interactions between HIV Rev and nuclear import and export factors: The Rev nuclear localisation signal mediates specific binding to human importin-beta. J. Mol. Biol. 1997, 274, 693-707. [CrossRef] [PubMed]

161. Emerman, M.; Malim, M.H. HIV-1 regulatory/accessory genes: Keys to unraveling viral and host cell biology. Science 1998, 280, 1880-1884. [CrossRef]

162. Bogerd, H.P.; Echarri, A.; Ross, T.M.; Cullen, B.R. Inhibition of human immunodeficiency virus Rev and human T-cell leukemia virus Rex function, but not Mason-Pfizer monkey virus constitutive transport element activity, by a mutant human nucleoporin targeted to Crm1. J. Virol. 1998, 72, 8627-8635. [CrossRef] [PubMed]

163. Hofmann, W.; Reichart, B.; Ewald, A.; Müller, E.; Schmitt, I.; Stauber, R.H.; Lottspeich, F.; Jockusch, B.M.; Scheer, U.; Hauber, J.; et al. Cofactor requirements for nuclear export of Rev response element (RRE)- and constitutive transport element (CTE)containing retroviral RNAs. An unexpected role for actin. J. Cell Biol. 2001, 152, 895-910. [CrossRef] [PubMed]

164. Ullman, K.S.; Shah, S.; Powers, M.A.; Forbes, D.J. The nucleoporin nup153 plays a critical role in multiple types of nuclear export. Mol. Biol. Cell 1999, 10, 649-664. [CrossRef]

165. Zolotukhin, A.S.; Felber, B.K. Nucleoporins nup98 and nup214 participate in nuclear export of human immunodeficiency virus type 1 Rev. J. Virol. 1999, 73, 120-127. [CrossRef]

166. Monette, A.; Panté, N.; Mouland, A.J. HIV-1 remodels the nuclear pore complex. J. Cell Biol. 2011, 193, 619-631. [CrossRef]

167. Taniguchi, I.; Mabuchi, N.; Ohno, M. HIV-1 Rev protein specifies the viral RNA export pathway by suppressing TAP/NXF1 recruitment. Nucl. Acids Res. 2014, 42, 6645-6658. [CrossRef] [PubMed] 
168. McCauley, S.M.; Kim, K.; Nowosielska, A.; Dauphin, A.; Yurkovetskiy, L.; Diehl, W.E.; Luban, J. Intron-containing RNA from the HIV-1 provirus activates type I interferon and inflammatory cytokines. Nat. Commun. 2018, 9, 5305. [CrossRef]

169. Te Velthuis, A.J.W.; Grimes, J.M.; Fodor, E. Structural insights into RNA polymerases of negative-sense RNA viruses. Nat. Rev. Microbiol. 2021, 19, 303-318. [CrossRef]

170. O'Neill, R.E.; Jaskunas, R.; Blobel, G.; Palese, P.; Moroianu, J. Nuclear import of influenza virus RNA can be mediated by viral nucleoprotein and transport factors required for protein import. J. Biol. Chem. 1995, 270, 22701-22704. [CrossRef]

171. Wang, P.; Palese, P.; O'Neill, R.E. The NPI-1/NPI-3 (karyopherin alpha) binding site on the influenza a virus nucleoprotein NP is a nonconventional nuclear localization signal. J. Virol. 1997, 71, 1850-1856. [CrossRef]

172. Weber, F.; Kochs, G.; Gruber, S.; Haller, O. A classical bipartite nuclear localization signal on Thogoto and influenza A virus nucleoproteins. Virology 1998, 250, 9-18. [CrossRef] [PubMed]

173. Cros, J.F.; García-Sastre, A.; Palese, P. An unconventional NLS is critical for the nuclear import of the influenza A virus nucleoprotein and ribonucleoprotein. Traffic 2005, 6, 205-213. [CrossRef] [PubMed]

174. Donchet, A.; Vassal-Stermann, E.; Gérard, F.C.A.; Ruigrok, R.W.H.; Crépin, T. Differential behaviours and preferential bindings of influenza nucleoproteins on importins- $\alpha$. Viruses 2020, 12, 834. [CrossRef] [PubMed]

175. Tarendeau, F.; Boudet, J.; Guilligay, D.; Mas, P.J.; Bougault, C.M.; Boulo, S.; Baudin, F.; Ruigrok, R.W.; Daigle, N.; Ellenberg, J.; et al. Structure and nuclear import function of the C-terminal domain of influenza virus polymerase PB2 subunit. Nat. Struct. Mol. Biol. 2007, 14, 229-233. [CrossRef]

176. Gabriel, G.; Herwig, A.; Klenk, H.D. Interaction of polymerase subunit PB2 and NP with importin alpha1 is a determinant of host range of influenza A virus. PLoS Pathog. 2008, 4, e11. [CrossRef] [PubMed]

177. Hudjetz, B.; Gabriel, G. Human-like PB2 627K influenza virus polymerase activity is regulated by importin- $\alpha 1$ and $-\alpha 7$. PLoS Pathog. 2012, 8, e1002488. [CrossRef]

178. Pumroy, R.A.; Ke, S.; Hart, D.J.; Zachariae, U.; Cingolani, G. Molecular determinants for nuclear import of influenza A PB2 by importin $\alpha$ isoforms 3 and 7. Structure 2015, 23, 374-384. [CrossRef] [PubMed]

179. Thiele, S.; Stanelle-Bertram, S.; Beck, S.; Kouassi, N.M.; Zickler, M.; Müller, M.; Tuku, B.; Resa-Infante, P.; van Riel, D.; Alawi, M.; et al. Cellular Importin- $\alpha 3$ Expression Dynamics in the Lung Regulate Antiviral Response Pathways against Influenza A Virus Infection. Cell Rep. 2020, 31, 107549. [CrossRef]

180. Swale, C.; Monod, A.; Tengo, L.; Labaronne, A.; Garzoni, F.; Bourhis, J.M.; Cusack, S.; Schoehn, G.; Berger, I.; Ruigrok, R.W.; et al. Structural characterization of recombinant IAV polymerase reveals a stable complex between viral PA-PB1 heterodimer and host RanBP5. Sci. Rep. 2016, 6, 24727. [CrossRef]

181. Swale, C.; Da Costa, B.; Sedano, L.; Garzoni, F.; McCarthy, A.A.; Berger, I.; Bieniossek, C.; Ruigrok, R.W.H.; Delmas, B.; Crépin, T. X-ray structure of the human karyopherin RanBP5, an essential factor for influenza polymerase nuclear trafficking. J. Mol. Biol. 2020, 432, 3353-3359. [CrossRef]

182. Brunotte, L.; Flies, J.; Bolte, H.; Reuther, P.; Vreede, F.; Schwemmle, M. The nuclear export protein of H5N1 influenza A viruses recruits Matrix 1 (M1) protein to the viral ribonucleoprotein to mediate nuclear export. J. Biol. Chem. 2014, 289, 20067-20077. [CrossRef]

183. Gao, S.; Wang, S.; Cao, S.; Sun, L.; Li, J.; Bi, Y.; Gao, G.F.; Liu, W. Characteristics of nucleocytoplasmic transport of H1N1 influenza A virus nuclear export protein. J. Virol. 2014, 88, 7455-7463. [CrossRef]

184. Satterly, N.; Tsai, P.L.; van Deursen, J.; Nussenzveig, D.R.; Wang, Y.; Faria, P.A.; Levay, A.; Levy, D.E.; Fontoura, B.M. Influenza virus targets the mRNA export machinery and the nuclear pore complex. Proc. Nat. Acad. Sci. USA 2007, 104, 1853-1858. [CrossRef] [PubMed]

185. Zhang, K.; Xie, Y.; Muñoz-Moreno, R.; Wang, J.; Zhang, L.; Esparza, M.; García-Sastre, A.; Fontoura, B.M.A.; Ren, Y. Structural basis for influenza virus NS1 protein block of mRNA nuclear export. Nat. Microb. 2019, 4, 1671-1679. [CrossRef]

186. Nemeroff, M.E.; Barabino, S.M.; Li, Y.; Keller, W.; Krug, R.M. Influenza virus NS1 protein interacts with the cellular 30 kDa subunit of CPSF and inhibits $3^{\prime}$ end formation of cellular pre-mRNAs. Mol. Cell 1998, 1, 991-1000. [CrossRef]

187. Chen, Z.; Li, Y.; Krug, R.M. Influenza A virus NS1 protein targets poly(A)-binding protein II of the cellular $3^{\prime}$-end processing machinery. EMBO J. 1999, 18, 2273-2283. [CrossRef]

188. Morita, M.; Kuba, K.; Ichikawa, A.; Nakayama, M.; Katahira, J.; Iwamoto, R.; Watanebe, T.; Sakabe, S.; Daidoji, T.; Nakamura, S.; et al. The lipid mediator protectin D1 inhibits influenza virus replication and improves severe influenza. Cell 2013, 153, 112-125. [CrossRef]

189. Van Doorslaer, K.; Chen, Z.; Bernard, H.U.; Chan, P.K.S.; DeSalle, R.; Dillner, J.; Forslund, O.; Haga, T.; McBride, A.A.; Villa, L.L.; et al. ICTV Virus Taxonomy Profile: Papillomaviridae. J. Gen. Virol. 2018, 99, 989-990. [CrossRef]

190. Muñoz, N.; Bosch, F.X.; de Sanjosé, S.; Herrero, R.; Castellsagué, X.; Shah, K.V.; Snijders, P.J.; Meijer, C.J. Epidemiologic classification of human papillomavirus types associated with cervical cancer. N. Eng. J. Med. 2003, 348, 518-527. [CrossRef]

191. Aydin, I.; Weber, S.; Snijder, B.; Samperio Ventayol, P.; Kühbacher, A.; Becker, M.; Day, P.M.; Schiller, J.T.; Kann, M.; Pelkmans, L.; et al. Large scale RNAi reveals the requirement of nuclear envelope breakdown for nuclear import of human papillomaviruses. PLoS Pathog. 2014, 10, e1004162. [CrossRef]

192. Pyeon, D.; Pearce, S.M.; Lank, S.M.; Ahlquist, P.; Lambert, P.F. Establishment of human papillomavirus infection requires cell cycle progression. PLoS Pathog. 2009, 5, e1000318. [CrossRef] 
193. Tao, M.; Kruhlak, M.; Xia, S.; Androphy, E.; Zheng, Z.M. Signals that dictate nuclear localization of human papillomavirus type 16 oncoprotein E6 in living cells. J. Virol. 2003, 77, 13232-13247. [CrossRef]

194. Le Roux, L.G.; Moroianu, J. Nuclear entry of high-risk human papillomavirus type 16 E6 oncoprotein occurs via several pathways. J. Virol. 2003, 77, 2330-2337. [CrossRef]

195. Masson, M.; Hindelang, C.; Sibler, A.P.; Schwalbach, G.; Travé, G.; Weiss, E. Preferential nuclear localization of the human papillomavirus type 16 E6 oncoprotein in cervical carcinoma cells. J. Gen. Virol. 2003, 84, 2099-2104. [CrossRef]

196. Freedman, D.A.; Levine, A.J. Nuclear export is required for degradation of endogenous p53 by MDM2 and human papillomavirus E6. Mol. Cell. Biol. 1998, 18, 7288-7293. [CrossRef]

197. Stewart, D.; Ghosh, A.; Matlashewski, G. Involvement of nuclear export in human papillomavirus type 18 E6-mediated ubiquitination and degradation of p53. J. Virol. 2005, 79, 8773-8783. [CrossRef]

198. McLaughlin-Drubin, M.E.; Münger, K. The human papillomavirus E7 oncoprotein. Virology 2009, 384, 335-344. [CrossRef]

199. Angeline, M.; Merle, E.; Moroianu, J. The E7 oncoprotein of high-risk human papillomavirus type 16 enters the nucleus via a nonclassical Ran-dependent pathway. Virology 2003, 317, 13-23. [CrossRef]

200. Knapp, A.A.; McManus, P.M.; Bockstall, K.; Moroianu, J. Identification of the nuclear localization and export signals of high risk HPV16 E7 oncoprotein. Virology 2009, 383, 60-68. [CrossRef] [PubMed]

201. Eberhard, J.; Onder, Z.; Moroianu, J. Nuclear import of high risk HPV16 E7 oncoprotein is mediated by its zinc-binding domain via hydrophobic interactions with Nup62. Virology 2013, 446, 334-345. [CrossRef]

202. Onder, Z.; Moroianu, J. Nuclear import of cutaneous beta genus HPV8 E7 oncoprotein is mediated by hydrophobic interactions between its zinc-binding domain and FG nucleoporins. Virology 2014, 449, 150-162. [CrossRef]

203. McKee, C.H.; Onder, Z.; Ashok, A.; Cardoso, R.; Moroianu, J. Characterization of the transport signals that mediate the nucleocytoplasmic traffic of low risk HPV11 E7. Virology 2013, 443, 113-122. [CrossRef]

204. Deng, W.; Lin, B.Y.; Jin, G.; Wheeler, C.G.; Ma, T.; Harper, J.W.; Broker, T.R.; Chow, L.T. Cyclin/CDK regulates the nucleocytoplasmic localization of the human papillomavirus E1 DNA helicase. J. Virol. 2004, 78, 13954-13965. [CrossRef] [PubMed]

205. Egawa, N.; Wang, Q.; Griffin, H.M.; Murakami, I.; Jackson, D.; Mahmood, R.; Doorbar, J. HPV16 and 18 genome amplification show different E4-dependence, with 16E4 enhancing E1 nuclear accumulation and replicative efficiency via its cell cycle arrest and kinase activation functions. PLoS Pathog. 2017, 13, e1006282. [CrossRef]

206. Yu, J.H.; Lin, B.Y.; Deng, W.; Broker, T.R.; Chow, L.T. Mitogen-activated protein kinases activate the nuclear localization sequence of human papillomavirus type 11 E1 DNA helicase to promote efficient nuclear import. J. Virol. 2007, 81, 5066-5078. [CrossRef] [PubMed]

207. Bian, X.L.; Rosas-Acosta, G.; Wu, Y.C.; Wilson, V.G. Nuclear import of bovine papillomavirus type 1 E1 protein is mediated by multiple alpha importins and is negatively regulated by phosphorylation near a nuclear localization signal. J. Virol. 2007, 81, 2899-2908. [CrossRef] [PubMed]

208. Fradet-Turcotte, A.; Moody, C.; Laimins, L.A.; Archambault, J. Nuclear export of human papillomavirus type 31 E1 is regulated by Cdk2 phosphorylation and required for viral genome maintenance. J. Virol. 2010, 84, 11747-11760. [CrossRef] [PubMed]

209. Blachon, S.; Bellanger, S.; Demeret, C.; Thierry, F. Nucleo-cytoplasmic shuttling of high risk human Papillomavirus E2 proteins induces apoptosis. J. Biol. Chem. 2005, 280, 36088-36098. [CrossRef] [PubMed]

210. Klucevsek, K.; Wertz, M.; Lucchi, J.; Leszczynski, A.; Moroianu, J. Characterization of the nuclear localization signal of high risk HPV16 E2 protein. Virology 2007, 360, 191-198. [CrossRef]

211. Nelson, L.M.; Rose, R.C.; Moroianu, J. Nuclear import strategies of high risk HPV16 L1 major capsid protein. J. Biol. Chem. 2002, 277, 23958-23964. [CrossRef] [PubMed]

212. Darshan, M.S.; Lucchi, J.; Harding, E.; Moroianu, J. The 12 minor capsid protein of human papillomavirus type 16 interacts with a network of nuclear import receptors. J. Virol. 2004, 78, 12179-12188. [CrossRef] [PubMed]

213. Papaevangelou, G.; Roumeliotou-Karayannis, A.; Tassopoulos, N.; Kolaitis, N.; Contoyannis, P.; Krugman, S. Post-exposure hepatitis B vaccination of sexual partners of acute viral hepatitis patients. J. Infect. 1983, 7, 63-67. [CrossRef]

214. Chaturvedi, V.K.; Singh, A.; Dubey, S.K.; Hetta, H.F.; John, J.; Singh, M.P. Molecular mechanistic insight of hepatitis B virus mediated hepatocellular carcinoma. Microb. Pathog. 2019, 128, 184-194. [CrossRef]

215. Nassal, M. HBV cccDNA: Viral persistence reservoir and key obstacle for a cure of chronic hepatitis B. Gut 2015, 64, 1972-1984. [CrossRef]

216. Kann, M.; Sodeik, B.; Vlachou, A.; Gerlich, W.H.; Helenius, A. Phosphorylation-dependent binding of hepatitis B virus core particles to the nuclear pore complex. J. Cell Biol. 1999, 145, 45-55. [CrossRef]

217. Rabe, B.; Vlachou, A.; Panté, N.; Helenius, A.; Kann, M. Nuclear import of hepatitis B virus capsids and release of the viral genome. Proc. Nat. Acad. Sci. USA 2003, 100, 9849-9854. [CrossRef]

218. Guo, H.; Mao, R.; Block, T.M.; Guo, J.T. Production and function of the cytoplasmic deproteinized relaxed circular DNA of hepadnaviruses. J. Virol. 2010, 84, 387-396. [CrossRef]

219. Schmitz, A.; Schwarz, A.; Foss, M.; Zhou, L.; Rabe, B.; Hoellenriegel, J.; Stoeber, M.; Panté, N.; Kann, M. Nucleoporin 153 arrests the nuclear import of hepatitis B virus capsids in the nuclear basket. PLoS Pathog. 2010, 6, e1000741. [CrossRef]

220. Li, H.C.; Huang, E.Y.; Su, P.Y.; Wu, S.Y.; Yang, C.C.; Lin, Y.S.; Chang, W.C.; Shih, C. Nuclear export and import of human hepatitis B virus capsid protein and particles. PLoS Pathog. 2010, 6, e1001162. [CrossRef] 
221. Nair, S.; Zlotnick, A. HBV Core protein is in flux between cytoplasmic, nuclear, and nucleolar compartments. $m$ Bio $2021,12$. [CrossRef] [PubMed]

222. Chen, C.; Wang, J.C.; Pierson, E.E.; Keifer, D.Z.; Delaleau, M.; Gallucci, L.; Cazenave, C.; Kann, M.; Jarrold, M.F.; Zlotnick, A. Importin $\beta$ can bind hepatitis b virus core protein and empty core-like particles and induce structural changes. PLoS Pathog. 2016, 12, e1005802. [CrossRef]

223. Mitra, B.; Wang, J.; Kim, E.S.; Mao, R.; Dong, M.; Liu, Y.; Zhang, J.; Guo, H. Hepatitis B Virus Precore Protein p22 Inhibits Alpha Interferon Signaling by Blocking STAT Nuclear Translocation. J. Virol. 2019, 93. [CrossRef]

224. Dai, X.; Zhou, Z.H. Structure of the herpes simplex virus 1 capsid with associated tegument protein complexes. Science 2018, 360, eaao7298. [CrossRef]

225. Pasdeloup, D.; Blondel, D.; Isidro, A.L.; Rixon, F.J. Herpesvirus capsid association with the nuclear pore complex and viral DNA release involve the nucleoporin CAN/Nup214 and the capsid protein pUL25. J. Virol. 2009, 83, 6610-6623. [CrossRef]

226. Copeland, A.M.; Newcomb, W.W.; Brown, J.C. Herpes simplex virus replication: Roles of viral proteins and nucleoporins in capsid-nucleus attachment. J. Virol. 2009, 83, 1660-1668. [CrossRef]

227. Abaitua, F.; Hollinshead, M.; Bolstad, M.; Crump, C.M.; O'Hare, P. A Nuclear localization signal in herpesvirus protein VP1-2 is essential for infection via capsid routing to the nuclear pore. J. Virol. 2012, 86, 8998-9014. [CrossRef] [PubMed]

228. Ojala, P.M.; Sodeik, B.; Ebersold, M.W.; Kutay, U.; Helenius, A. Herpes simplex virus type 1 entry into host cells: Reconstitution of capsid binding and uncoating at the nuclear pore complex in vitro. Mol. Cell. Biol. 2000, 20, 4922-4931. [CrossRef] [PubMed]

229. Döhner, K.; Ramos-Nascimento, A.; Bialy, D.; Anderson, F.; Hickford-Martinez, A.; Rother, F.; Koithan, T.; Rudolph, K.; Buch, A.; Prank, U.; et al. Importin $\alpha 1$ is required for nuclear import of herpes simplex virus proteins and capsid assembly in fibroblasts and neurons. PLoS Pathog. 2018, 14, e1006823. [CrossRef] [PubMed]

230. Marsden, H.S.; Murphy, M.; McVey, G.L.; MacEachran, K.A.; Owsianka, A.M.; Stow, N.D. Role of the carboxy terminus of herpes simplex virus type 1 DNA polymerase in its interaction with UL42. J. Gen. Virol. 1994, 75, 3127-3135. [CrossRef]

231. Loregian, A.; Piaia, E.; Cancellotti, E.; Papini, E.; Marsden, H.S.; Palù, G. The catalytic subunit of herpes simplex virus type 1 DNA polymerase contains a nuclear localization signal in the UL42-binding region. Virology 2000, 273, 139-148. [CrossRef]

232. Alvisi, G.; Musiani, D.; Jans, D.A.; Ripalti, A. An importin alpha/beta-recognized bipartite nuclear localization signal mediates targeting of the human herpes simplex virus type 1 DNA polymerase catalytic subunit pUL30 to the nucleus. Biochemistry 2007, 46, 9155-9163. [CrossRef] [PubMed]

233. Alvisi, G.; Avanzi, S.; Musiani, D.; Camozzi, D.; Leoni, V.; Ly-Huynh, J.D.; Ripalti, A. Nuclear import of HSV-1 DNA polymerase processivity factor UL42 is mediated by a C-terminally located bipartite nuclear localization signal. Biochemistry 2008, 47, 13764-13777. [CrossRef]

234. Yusuf, B.; Gopurappilly, R.; Dadheech, N.; Gupta, S.; Bhonde, R.; Pal, R. Embryonic fibroblasts represent a connecting link between mesenchymal and embryonic stem cells. Dev. Growth Differ. 2013, 55, 330-340. [CrossRef] [PubMed]

235. Smith, R.W.; Malik, P.; Clements, J.B. The herpes simplex virus ICP27 protein: A multifunctional post-transcriptional regulator of gene expression. Biochem. Soc. Trans. 2005, 33, 499-501. [CrossRef]

236. Sandri-Goldin, R.M. The many roles of the regulatory protein ICP27 during herpes simplex virus infection. Front. Biosci. J. Virtual Librar. 2008, 13, 5241-5256. [CrossRef] [PubMed]

237. Chen, I.H.; Li, L.; Silva, L.; Sandri-Goldin, R.M. ICP27 recruits Aly/REF but not TAP/NXF1 to herpes simplex virus type 1 transcription sites although TAP/NXF1 is required for ICP27 export. J. Virol. 2005, 79, 3949-3961. [CrossRef]

238. Escudero-Paunetto, L.; Li, L.; Hernandez, F.P.; Sandri-Goldin, R.M. SR proteins SRp20 and 9G8 contribute to efficient export of herpes simplex virus 1 mRNAs. Virology 2010, 401, 155-164. [CrossRef]

239. Koffa, M.D.; Clements, J.B.; Izaurralde, E.; Wadd, S.; Wilson, S.A.; Mattaj, I.W.; Kuersten, S. Herpes simplex virus ICP27 protein provides viral mRNAs with access to the cellular mRNA export pathway. EMBO J. 2001, 20, 5769-5778. [CrossRef] [PubMed]

240. Malik, P.; Tabarraei, A.; Kehlenbach, R.H.; Korfali, N.; Iwasawa, R.; Graham, S.V.; Schirmer, E.C. Herpes simplex virus ICP27 protein directly interacts with the nuclear pore complex through Nup62, inhibiting host nucleocytoplasmic transport pathways. J. Biol. Chem. 2012, 287, 12277-12292. [CrossRef]

241. Boruchowicz, H.; Hawkins, J.; Cruz-Palomar, K.; Lippé, R. The XPO6 Exportin Mediates Herpes Simplex Virus 1 gM Nuclear Release Late in Infection. J. Virol. 2020, 94. [CrossRef] [PubMed]

242. Walter, G.; Richert, Q.; Ponnampalam, A.; Sharma, A. Acute superior mesenteric vein thrombosis in the setting of cytomegalovirus mononucleosis: A case report and review of the literature. Lancet Infect. Dis. 2021. [CrossRef]

243. Bowen, L.N.; Smith, B.; Reich, D.; Quezado, M.; Nath, A. HIV-associated opportunistic CNS infections: Pathophysiology, diagnosis and treatment. Nat. Rev. Neurol. 2016, 12, 662-674. [CrossRef] [PubMed]

244. Gill, R.B.; James, S.H.; Prichard, M.N. Human cytomegalovirus UL97 kinase alters the accumulation of CDK1. J. Gen. Virol. 2012, 93, 1743-1755. [CrossRef]

245. Webel, R.; Solbak, S.; Held, C.; Milbradt, J.; Groß, A.; Eichler, J.; Wittenberg, T.; Jardin, C.; Sticht, H.; Fossen, T.; et al. Nuclear import of isoforms of the cytomegalovirus kinase pUL97 is mediated by differential activity of NLS1 and NLS2 both acting through classical importin- $\alpha$ binding. J. Gen. Virol. 2012, 93, 1756-1768. [CrossRef]

246. Perng, Y.C.; Campbell, J.A.; Lenschow, D.J.; Yu, D. Human cytomegalovirus pUL79 is an elongation factor of RNA polymerase II for viral gene transcription. PLoS Pathog. 2014, 10, e1004350. [CrossRef] 
247. Wang, L.; Li, M.; Cai, M.; Xing, J.; Wang, S.; Zheng, C. A PY-nuclear localization signal is required for nuclear accumulation of HCMV UL79 protein. Med. Microbiol. Immunol. 2012, 201, 381-387. [CrossRef]

248. Gao, Y.; Kagele, D.; Smallenberg, K.; Pari, G.S. Nucleocytoplasmic shuttling of human cytomegalovirus UL84 is essential for virus growth. J. Virol. 2010, 84, 8484-8494. [CrossRef]

249. Lischka, P.; Sorg, G.; Kann, M.; Winkler, M.; Stamminger, T. A nonconventional nuclear localization signal within the UL84 protein of human cytomegalovirus mediates nuclear import via the importin alpha/beta pathway. J. Virol. 2003, 77, 3734-3748. [CrossRef]

250. Lischka, P.; Rauh, C.; Mueller, R.; Stamminger, T. Human cytomegalovirus UL84 protein contains two nuclear export signals and shuttles between the nucleus and the cytoplasm. J. Virol. 2006, 80, 10274-10280. [CrossRef]

251. Toth, Z.; Lischka, P.; Stamminger, T. RNA-binding of the human cytomegalovirus transactivator protein UL69, mediated by arginine-rich motifs, is not required for nuclear export of unspliced RNA. Nucl. Acids Res. 2006, 34, 1237-1249. [CrossRef] [PubMed]

252. Zielke, B.; Thomas, M.; Giede-Jeppe, A.; Müller, R.; Stamminger, T. Characterization of the betaherpesviral pUL69 protein family reveals binding of the cellular mRNA export factor UAP56 as a prerequisite for stimulation of nuclear mRNA export and for efficient viral replication. J. Virol. 2011, 85, 1804-1819. [CrossRef] [PubMed]

253. Stamminger, T. Interactions of human cytomegalovirus proteins with the nuclear transport machinery. Curr. Top. Microbiol. Immunol. 2008, 325, 167-185. [CrossRef] [PubMed]

254. Lischka, P.; Rosorius, O.; Trommer, E.; Stamminger, T. A novel transferable nuclear export signal mediates CRM1-independent nucleocytoplasmic shuttling of the human cytomegalovirus transactivator protein pUL69. EMBO J. 2001, 20, 7271-7283. [CrossRef]

255. Rechter, S.; Scott, G.M.; Eickhoff, J.; Zielke, K.; Auerochs, S.; Müller, R.; Stamminger, T.; Rawlinson, W.D.; Marschall, M. Cyclindependent Kinases Phosphorylate the Cytomegalovirus RNA Export Protein pUL69 and Modulate Its Nuclear Localization and Activity. J. Biol. Chem. 2009, 284, 8605-8613. [CrossRef] [PubMed]

256. Münz, C. Latency and lytic replication in Epstein-Barr virus-associated oncogenesis. Nat. Rev. Microbiol. 2019, 17, 691-700. [CrossRef]

257. Ito, S.; Ikeda, M.; Kato, N.; Matsumoto, A.; Ishikawa, Y.; Kumakubo, S.; Yanagi, K. Epstein-barr virus nuclear antigen-1 binds to nuclear transporter karyopherin alpha1/NPI-1 in addition to karyopherin alpha2/Rch1. Virology 2000, 266, 110-119. [CrossRef]

258. Chang, C.W.; Lee, C.P.; Su, M.T.; Tsai, C.H.; Chen, M.R. BGLF4 kinase modulates the structure and transport preference of the nuclear pore complex to facilitate nuclear import of Epstein-Barr virus lytic proteins. J. Virol. 2015, 89, 1703-1718. [CrossRef]

259. Lee, C.P.; Huang, Y.H.; Lin, S.F.; Chang, Y.; Chang, Y.H.; Takada, K.; Chen, M.R. Epstein-Barr virus BGLF4 kinase induces disassembly of the nuclear lamina to facilitate virion production. J. Virol. 2008, 82, 11913-11926. [CrossRef] [PubMed]

260. Sharma, M.; Kamil, J.P.; Coughlin, M.; Reim, N.I.; Coen, D.M. Human cytomegalovirus UL50 and UL53 recruit viral protein kinase UL97, not protein kinase C, for disruption of nuclear lamina and nuclear egress in infected cells. J. Virol. 2014, 88, 249-262. [CrossRef]

261. Yang, Y.C.; Sugden, B. Epstein-Barr Virus Limits the Accumulation of IPO7, an Essential Gene Product. Front. Microbiol. 2021, 12, 643327. [CrossRef] [PubMed]

262. Ye, J.; Gradoville, L.; Miller, G. Cellular immediate-early gene expression occurs kinetically upstream of Epstein-Barr virus bzlf1 and brlf1 following cross-linking of the B cell antigen receptor in the Akata Burkitt lymphoma cell line. J. Virol. 2010, 84, 12405-12418. [CrossRef]

263. Boyle, S.M.; Ruvolo, V.; Gupta, A.K.; Swaminathan, S. Association with the cellular export receptor CRM 1 mediates function and intracellular localization of Epstein-Barr virus SM protein, a regulator of gene expression. J. Virol. 1999, 73, 6872-6881. [CrossRef] [PubMed]

264. Funk, C.; Ott, M.; Raschbichler, V.; Nagel, C.H.; Binz, A.; Sodeik, B.; Bauerfeind, R.; Bailer, S.M. The herpes simplex virus protein pUL31 escorts nucleocapsids to sites of nuclear egress, a process coordinated by its N-terminal domain. PLoS Pathog. 2015, 11, e1004957. [CrossRef]

265. Gonnella, R.; Farina, A.; Santarelli, R.; Raffa, S.; Feederle, R.; Bei, R.; Granato, M.; Modesti, A.; Frati, L.; Delecluse, H.J.; et al. Characterization and intracellular localization of the Epstein-Barr virus protein BFLF2: Interactions with BFRF1 and with the nuclear lamina. J. Virol. 2005, 79, 3713-3727. [CrossRef] [PubMed]

266. Schmeiser, C.; Borst, E.; Sticht, H.; Marschall, M.; Milbradt, J. The cytomegalovirus egress proteins pUL50 and pUL53 are translocated to the nuclear envelope through two distinct modes of nuclear import. J. Gen. Virol. 2013, 94, 2056-2069. [CrossRef]

267. Li, M.; Chen, T.; Zou, X.; Xu, Z.; Wang, Y.; Wang, P.; Ou, X.; Li, Y.; Chen, D.; Peng, T.; et al. Characterization of the nucleocytoplasmic transport mechanisms of epstein-barr virus BFLF2. Cell. Physiol. Biochem. 2018, 51, 1500-1517. [CrossRef] [PubMed]

268. Li, M.; Jiang, S.; Mo, C.; Zeng, Z.; Li, X.; Chen, C.; Yang, Y.; Wang, J.; Huang, J.; Chen, D.; et al. Identification of molecular determinants for the nuclear import of pseudorabies virus UL31. Arch. Biochem. Biophys. 2015, 587, 12-17. [CrossRef] [PubMed]

269. Cai, M.; Chen, D.; Zeng, Z.; Yang, H.; Jiang, S.; Li, X.; Mai, J.; Peng, T.; Li, M. Characterization of the nuclear import signal of herpes simplex virus 1 UL31. Arch. Virol. 2016, 161, 2379-2385. [CrossRef]

270. Paßvogel, L.; Klupp, B.G.; Granzow, H.; Fuchs, W.; Mettenleiter, T.C. Functional characterization of nuclear trafficking signals in pseudorabies virus pUL31. J. Virol. 2015, 89, 2002-2012. [CrossRef] 
271. Funk, C.; Raschbichler, V.; Lieber, D.; Wetschky, J.; Arnold, E.K.; Leimser, J.; Biggel, M.; Friedel, C.C.; Ruzsics, Z.; Bailer, S.M. Comprehensive analysis of nuclear export of herpes simplex virus type 1 tegument proteins and their Epstein-Barr virus orthologs. Traffic 2019, 20, 152-167. [CrossRef]

272. Gabriel, G.; Klingel, K.; Otte, A.; Thiele, S.; Hudjetz, B.; Arman-Kalcek, G.; Sauter, M.; Shmidt, T.; Rother, F.; Baumgarte, S.; et al. Differential use of importin- $\alpha$ isoforms governs cell tropism and host adaptation of influenza virus. Nat. Commun. 2011, 2, 156. [CrossRef]

273. Higgs, E.S.; Gayedyu-Dennis, D.; Fisher, W.; Nason, M.; Reilly, C.; Beavogui, A.H.; Aboulhab, J.; Nordwall, J.; Lobbo, P.; Wachekwa, I.; et al. PREVAIL IV: A Randomized, Double-Blind, Two-Phase, Phase 2 Trial of Remdesivir versus Placebo for Reduction of Ebola Virus RNA in the Semen of Male Survivors. Clin. Infect. Dis. 2021. [CrossRef]

274. Choopanya, K.; Martin, M.; Suntharasamai, P.; Sangkum, U.; Mock, P.A.; Leethochawalit, M.; Chiamwongpaet, S.; Kitisin, P.; Natrujirote, P.; Kittimunkong, S.; et al. Antiretroviral prophylaxis for HIV infection in injecting drug users in Bangkok, Thailand (the Bangkok Tenofovir Study): A randomised, double-blind, placebo-controlled phase 3 trial. Lancet 2013, 381, $2083-2090$. [CrossRef]

275. Abdool Karim, S.S.; Abdool Karim, Q.; Kharsany, A.B.; Baxter, C.; Grobler, A.C.; Werner, L.; Kashuba, A.; Mansoor, L.E.; Samsunder, N.; Mindel, A.; et al. Tenofovir Gel for the Prevention of Herpes Simplex Virus Type 2 Infection. N. Engl. J. Med. 2015, 373, 530-539. [CrossRef]

276. Kosugi, S.; Hasebe, M.; Entani, T.; Takayama, S.; Tomita, M.; Yanagawa, H. Design of peptide inhibitors for the importin alpha/beta nuclear import pathway by activity-based profiling. Chem. Biol. 2008, 15, 940-949. [CrossRef] [PubMed]

277. Lin, Y.Z.; Yao, S.Y.; Veach, R.A.; Torgerson, T.R.; Hawiger, J. Inhibition of nuclear translocation of transcription factor NF-kappa B by a synthetic peptide containing a cell membrane-permeable motif and nuclear localization sequence. J. Biol. Chem. 1995, 270, 14255-14258. [CrossRef]

278. Zienkiewicz, J.; Armitage, A.; Hawiger, J. Targeting nuclear import shuttles, importins/karyopherins alpha by a peptide mimicking the NFkB1/p50 nuclear localization sequence. J. Am. Heart Assoc. 2013, 2, e000386. [CrossRef] [PubMed]

279. Tay, M.Y.; Fraser, J.E.; Chan, W.K.; Moreland, N.J.; Rathore, A.P.; Wang, C.; Vasudevan, S.G.; Jans, D.A. Nuclear localization of dengue virus (DENV) 1-4 non-structural protein 5; protection against all 4 DENV serotypes by the inhibitor Ivermectin. Antivir Res. 2013, 99, 301-306. [CrossRef] [PubMed]

280. Wagstaff, K.M.; Sivakumaran, H.; Heaton, S.M.; Harrich, D.; Jans, D.A. Ivermectin is a specific inhibitor of importin $\alpha / \beta$-mediated nuclear import able to inhibit replication of HIV-1 and dengue virus. Biochem. J. 2012, 443, 851-856. [CrossRef]

281. Yang, S.N.Y.; Atkinson, S.C.; Fraser, J.E.; Wang, C.; Maher, B.; Roman, N.; Forwood, J.K.; Wagstaff, K.M.; Borg, N.A.; Jans, D.A Novel flavivirus antiviral that targets the host nuclear transport importin $\alpha / \beta 1$ heterodimer. Cells 2019, 8, 281. [CrossRef]

282. Yang, S.N.Y.; Atkinson, S.C.; Wang, C.; Lee, A.; Bogoyevitch, M.A.; Borg, N.A.; Jans, D.A. The broad spectrum antiviral ivermectin targets the host nuclear transport importin $\alpha / \beta 1$ heterodimer. Antivir. Res. 2020, 177, 104760. [CrossRef] [PubMed]

283. Soderholm, J.F.; Bird, S.L.; Kalab, P.; Sampathkumar, Y.; Hasegawa, K.; Uehara-Bingen, M.; Weis, K.; Heald, R. Importazole, a small molecule inhibitor of the transport receptor importin- $\beta$. ACS Chem. Biol. 2011, 6, 700-708. [CrossRef] [PubMed]

284. Van der Watt, P.J.; Chi, A.; Stelma, T.; Stowell, C.; Strydom, E.; Carden, S.; Angus, L.; Hadley, K.; Lang, D.; Wei, W.; et al. Targeting the Nuclear Import Receptor Kpn $\beta 1$ as an Anticancer Therapeutic. Mol. Cancer Ther. 2016, 15, 560-573. [CrossRef] [PubMed]

285. Hintersteiner, M.; Ambrus, G.; Bednenko, J.; Schmied, M.; Knox, A.J.; Meisner, N.C.; Gstach, H.; Seifert, J.M.; Singer, E.L.; Gerace, L.; et al. Identification of a small molecule inhibitor of importin $\beta$ mediated nuclear import by confocal on-bead screening of tagged one-bead one-compound libraries. ACS Chem. Biol. 2010, 5, 967-979. [CrossRef] [PubMed]

286. Cansizoglu, A.E.; Lee, B.J.; Zhang, Z.C.; Fontoura, B.M.; Chook, Y.M. Structure-based design of a pathway-specific nuclear import inhibitor. Nat. Struct. Mol. Biol. 2007, 14, 452-454. [CrossRef] [PubMed]

287. Cai, M.; Ou, X.; Li, Y.; Zou, X.; Xu, Z.; Wang, Y.; Peng, H.; Deng, Y.; Guo, Y.; Lu, M.; et al. Molecular anatomy of the subcellular localization and nuclear import mechanism of herpes simplex virus 1 UL6. Aging 2020, 12, 5751-5763. [CrossRef] [PubMed]

288. Nishi, K.; Yoshida, M.; Fujiwara, D.; Nishikawa, M.; Horinouchi, S.; Beppu, T. Leptomycin B targets a regulatory cascade of crm1, a fission yeast nuclear protein, involved in control of higher order chromosome structure and gene expression. J. Biol. Chem. 1994, 269, 6320-6324. [CrossRef]

289. Kudo, N.; Matsumori, N.; Taoka, H.; Fujiwara, D.; Schreiner, E.P.; Wolff, B.; Yoshida, M.; Horinouchi, S. Leptomycin B inactivates CRM1/exportin 1 by covalent modification at a cysteine residue in the central conserved region. Proc. Nat. Acad. Sci. USA 1999, 96, 9112-9117. [CrossRef]

290. Zhang, K.; Wang, M.; Tamayo, A.T.; Shacham, S.; Kauffman, M.; Lee, J.; Zhang, L.; Ou, Z.; Li, C.; Sun, L.; et al. Novel selective inhibitors of nuclear export CRM1 antagonists for therapy in mantle cell lymphoma. Exp. Hematol. 2013, 41, 67-78.e64. [CrossRef]

291. Ranganathan, P.; Yu, X.; Na, C.; Santhanam, R.; Shacham, S.; Kauffman, M.; Walker, A.; Klisovic, R.; Blum, W.; Caligiuri, M.; et al. Preclinical activity of a novel CRM1 inhibitor in acute myeloid leukemia. Blood 2012, 120, 1765-1773. [CrossRef]

292. Sun, Q.; Carrasco, Y.P.; Hu, Y.; Guo, X.; Mirzaei, H.; Macmillan, J.; Chook, Y.M. Nuclear export inhibition through covalent conjugation and hydrolysis of Leptomycin B by CRM1. Proc. Nat. Acad. Sci. USA 2013, 110, 1303-1308. [CrossRef]

293. Lapalombella, R.; Sun, Q.; Williams, K.; Tangeman, L.; Jha, S.; Zhong, Y.; Goettl, V.; Mahoney, E.; Berglund, C.; Gupta, S.; et al. Selective inhibitors of nuclear export show that CRM1/XPO1 is a target in chronic lymphocytic leukemia. Blood 2012, 120, 4621-4634. [CrossRef] 
294. Haines, J.D.; Herbin, O.; de la Hera, B.; Vidaurre, O.G.; Moy, G.A.; Sun, Q.; Fung, H.Y.; Albrecht, S.; Alexandropoulos, K.; McCauley, D.; et al. Nuclear export inhibitors avert progression in preclinical models of inflammatory demyelination. Nat. Neurosci. 2015, 18, 511-520. [CrossRef] [PubMed]

295. Tai, Y.T.; Landesman, Y.; Acharya, C.; Calle, Y.; Zhong, M.Y.; Cea, M.; Tannenbaum, D.; Cagnetta, A.; Reagan, M.; Munshi, A.A.; et al. CRM1 inhibition induces tumor cell cytotoxicity and impairs osteoclastogenesis in multiple myeloma: Molecular mechanisms and therapeutic implications. Leukemia 2014, 28, 155-165. [CrossRef] [PubMed]

296. Newlands, E.S.; Rustin, G.J.; Brampton, M.H. Phase I trial of elactocin. Br. J. Cancer 1996, 74, 648-649. [CrossRef]

297. Sun, Q.; Chen, X.; Zhou, Q.; Burstein, E.; Yang, S.; Jia, D. Inhibiting cancer cell hallmark features through nuclear export inhibition. Signal Transduct. Target. Ther. 2016, 1, 16010. [CrossRef]

298. Wang, C.; Yang, S.N.Y.; Smith, K.; Forwood, J.K.; Jans, D.A. Nuclear import inhibitor N-(4-hydroxyphenyl) retinamide targets Zika virus (ZIKV) nonstructural protein 5 to inhibit ZIKV infection. Biochem. Biophys. Res. Commun. 2017, 493, 1555-1559. [CrossRef]

299. Pitts, J.D.; Li, P.C.; de Wispelaere, M.; Yang, P.L. Antiviral activity of N-(4-hydroxyphenyl) retinamide (4-HPR) against Zika virus. Antivir. Res. 2017, 147, 124-130. [CrossRef] [PubMed]

300. Fraser, J.E.; Watanabe, S.; Wang, C.; Chan, W.K.; Maher, B.; Lopez-Denman, A.; Hick, C.; Wagstaff, K.M.; Mackenzie, J.M.; Sexton, P.M.; et al. A nuclear transport inhibitor that modulates the unfolded protein response and provides in vivo protection against lethal dengue virus infection. J. Infect. Dis. 2014, 210, 1780-1791. [CrossRef]

301. Link, J.O.; Rhee, M.S.; Tse, W.C.; Zheng, J.; Somoza, J.R.; Rowe, W.; Begley, R.; Chiu, A.; Mulato, A.; Hansen, D.; et al. Clinical targeting of HIV capsid protein with a long-acting small molecule. Nature 2020, 584, 614-618. [CrossRef] [PubMed]

302. Yant, S.R.; Mulato, A.; Hansen, D.; Tse, W.C.; Niedziela-Majka, A.; Zhang, J.R.; Stepan, G.J.; Jin, D.; Wong, M.H.; Perreira, J.M.; et al. A highly potent long-acting small-molecule HIV-1 capsid inhibitor with efficacy in a humanized mouse model. Nat. Med. 2019, 25, 1377-1384. [CrossRef]

303. Mohl, G.; Liddle, N.; Nygaard, J.; Dorius, A.; Lyons, N.; Hodek, J.; Weber, J.; Michaelis, D.J.; Busath, D.D. Novel influenza inhibitors designed to target PB1 interactions with host importin RanBP5. Antivir. Res. 2019, 164, 81-90. [CrossRef]

304. Tanaka, K.; Kasahara, Y.; Miyamoto, Y.; Takumi, O.; Kasai, T.; Onodera, K.; Kuwahara, M.; Oka, M.; Yoneda, Y.; Obika, S. Development of oligonucleotide-based antagonists of Ebola virus protein 24 inhibiting its interaction with karyopherin alpha 1. Org. Biomol. Chem. 2018, 16, 4456-4463. [CrossRef]

305. Song, X.; Lu, L.Y.; Passioura, T.; Suga, H. Macrocyclic peptide inhibitors for the protein-protein interaction of Zaire Ebola virus protein 24 and karyopherin alpha 5. Org. Biomol. Chem. 2017, 15, 5155-5160. [CrossRef]

306. Gonzalez-Sanchez, J.L.; Martinez-Chequer, J.C.; Hernandez-Celaya, M.E.; Barahona-Bustillos, E.; Andrade-Manzano, A.F. Randomized placebo-controlled evaluation of intramuscular interferon beta treatment of recurrent human papillomavirus. Obstet. Gynecol. 2001, 97, 621-624. [CrossRef] [PubMed]

307. Terenzi, F.; Saikia, P.; Sen, G.C. Interferon-inducible protein, P56, inhibits HPV DNA replication by binding to the viral protein E1. EMBO J. 2008, 27, 3311-3321. [CrossRef]

308. Wu, G.; Liu, B.; Zhang, Y.; Li, J.; Arzumanyan, A.; Clayton, M.M.; Schinazi, R.F.; Wang, Z.; Goldmann, S.; Ren, Q.; et al. Preclinical characterization of GLS4, an inhibitor of hepatitis B virus core particle assembly. Antimicrob. Agents Chemother. 2013, 57, 5344-5354. [CrossRef] [PubMed]

309. Weber, O.; Schlemmer, K.H.; Hartmann, E.; Hagelschuer, I.; Paessens, A.; Graef, E.; Deres, K.; Goldmann, S.; Niewoehner, U.; Stoltefuss, J.; et al. Inhibition of human hepatitis B virus (HBV) by a novel non-nucleosidic compound in a transgenic mouse model. Antivir. Res. 2002, 54, 69-78. [CrossRef]

310. Brezillon, N.; Brunelle, M.N.; Massinet, H.; Giang, E.; Lamant, C.; DaSilva, L.; Berissi, S.; Belghiti, J.; Hannoun, L.; Puerstinger, G.; et al. Antiviral activity of Bay 41-4109 on hepatitis B virus in humanized Alb-uPA/SCID mice. PLoS ONE 2011, 6, e25096. [CrossRef]

311. Perni, R.B.; Conway, S.C.; Ladner, S.K.; Zaifert, K.; Otto, M.J.; King, R.W. Phenylpropenamide derivatives as inhibitors of hepatitis B virus replication. Bioorg. Med. Chem. Lett. 2000, 10, 2687-2690. [CrossRef]

312. King, R.W.; Ladner, S.K.; Miller, T.J.; Zaifert, K.; Perni, R.B.; Conway, S.C.; Otto, M.J. Inhibition of human hepatitis B virus replication by AT-61, a phenylpropenamide derivative, alone and in combination with (-)beta-L-2', $3^{\prime}$-dideoxy- $3^{\prime}$-thiacytidine. Antimicrob. Agents Chemother. 1998, 42, 3179-3186. [CrossRef] [PubMed]

313. Delaney, W.E.t.; Edwards, R.; Colledge, D.; Shaw, T.; Furman, P.; Painter, G.; Locarnini, S. Phenylpropenamide derivatives AT-61 and AT-130 inhibit replication of wild-type and lamivudine-resistant strains of hepatitis B virus in vitro. Antimicrob. Agents Chemother. 2002, 46, 3057-3060. [CrossRef] [PubMed]

314. Campagna, M.R.; Liu, F.; Mao, R.; Mills, C.; Cai, D.; Guo, F.; Zhao, X.; Ye, H.; Cuconati, A.; Guo, H.; et al. Sulfamoylbenzamide derivatives inhibit the assembly of hepatitis B virus nucleocapsids. J. Virol. 2013, 87, 6931-6942. [CrossRef]

315. Berke, J.M.; Dehertogh, P.; Vergauwen, K.; Van Damme, E.; Mostmans, W.; Vandyck, K.; Pauwels, F. Capsid Assembly Modulators Have a Dual Mechanism of Action in Primary Human Hepatocytes Infected with Hepatitis B Virus. Antimicrob. Agents Chemother. 2017, 61. [CrossRef]

316. Guo, F.; Zhao, Q.; Sheraz, M.; Cheng, J.; Qi, Y.; Su, Q.; Cuconati, A.; Wei, L.; Du, Y.; Li, W.; et al. HBV core protein allosteric modulators differentially alter cccDNA biosynthesis from de novo infection and intracellular amplification pathways. PLoS Pathog. 2017, 13, e1006658. [CrossRef] [PubMed] 
317. Ligat, G.; Goto, K.; Verrier, E.; Baumert, T.F. Targeting Viral cccDNA for Cure of Chronic Hepatitis, B. Curr. Hepatol. Rep. 2020, 19, 235-244. [CrossRef]

318. Caly, L.; Druce, J.D.; Catton, M.G.; Jans, D.A.; Wagstaff, K.M. The FDA-approved drug ivermectin inhibits the replication of SARS-CoV-2 in vitro. Antivir. Res. 2020, 178, 104787. [CrossRef]

319. Varghese, F.S.; Kaukinen, P.; Gläsker, S.; Bespalov, M.; Hanski, L.; Wennerberg, K.; Kümmerer, B.M.; Ahola, T. Discovery of berberine, abamectin and ivermectin as antivirals against chikungunya and other alphaviruses. Antivir. Res. 2016, 126, 117-124. [CrossRef]

320. King, C.R.; Tessier, T.M.; Dodge, M.J.; Weinberg, J.B.; Mymryk, J.S. Inhibition of Human Adenovirus Replication by the Importin $\alpha / \beta 1$ Nuclear Import Inhibitor Ivermectin. J. Virol. 2020, 94. [CrossRef]

321. Bennett, S.M.; Zhao, L.; Bosard, C.; Imperiale, M.J. Role of a nuclear localization signal on the minor capsid proteins VP2 and VP3 in BKPyV nuclear entry. Virology 2015, 474, 110-116. [CrossRef] [PubMed]

322. Lee, J.G.; Huang, W.; Lee, H.; van de Leemput, J.; Kane, M.A.; Han, Z. Characterization of SARS-CoV-2 proteins reveals Orf6 pathogenicity, subcellular localization, host interactions and attenuation by Selinexor. Cell Biosci. 2021, 11, 58. [CrossRef] [PubMed]

323. Perwitasari, O.; Johnson, S.; Yan, X.; Howerth, E.; Shacham, S.; Landesman, Y.; Baloglu, E.; McCauley, D.; Tamir, S.; Tompkins, S.M.; et al. Verdinexor, a novel selective inhibitor of nuclear export, reduces influenza a virus replication in vitro and in vivo. $J$. Virol. 2014, 88, 10228-10243. [CrossRef] [PubMed]

324. Perwitasari, O.; Johnson, S.; Yan, X.; Register, E.; Crabtree, J.; Gabbard, J.; Howerth, E.; Shacham, S.; Carlson, R.; Tamir, S.; et al. Antiviral Efficacy of Verdinexor In Vivo in Two Animal Models of Influenza A Virus Infection. PLoS ONE 2016, 11, e0167221. [CrossRef] [PubMed]

325. López-Medina, E.; López, P.; Hurtado, I.C.; Dávalos, D.M.; Ramirez, O.; Martínez, E.; Díazgranados, J.A.; Oñate, J.M.; Chavarriaga, H.; Herrera, S.; et al. Effect of ivermectin on time to resolution of symptoms among adults with mild COVID-19: A randomized clinical trial. JAMA 2021, 325, 1426-1435. [CrossRef] [PubMed]

326. Elalfy, H.; Besheer, T.; El-Mesery, A.; El-Gilany, A.H.; Soliman, M.A.; Alhawarey, A.; Alegezy, M.; Elhadidy, T.; Hewidy, A.A.; Zaghloul, H.; et al. Effect of a combination of nitazoxanide, ribavirin, and ivermectin plus zinc supplement (MANS.NRIZ study) on the clearance of mild COVID-19. J. Med. Virol. 2021, 93, 3176-3183. [CrossRef]

327. Ahmed, S.; Karim, M.M.; Ross, A.G.; Hossain, M.S.; Clemens, J.D.; Sumiya, M.K.; Phru, C.S.; Rahman, M.; Zaman, K.; Somani, J.; et al. A five-day course of ivermectin for the treatment of COVID-19 may reduce the duration of illness. Int. J. Infect. Dis. 2021, 103, 214-216. [CrossRef]

328. Gandhi, R.T.; Lynch, J.B.; del Rio, C. Mild or Moderate Covid-19. N. Engl. J. Med. 2020, 383, 1757-1766. [CrossRef] [PubMed]

329. Suputtamongkol, Y.; Avirutnan, P.; Mairiang, D.; Angkasekwinai, N.; Niwattayakul, K.; Yamasmith, E.; Saleh-Arong, F.A.; Songjaeng, A.; Prommool, T.; Tangthawornchaikul, N.; et al. Ivermectin accelerates circulating nonstructural protein 1 (NS1) clearance in adult dengue patients: A combined phase 2/3 randomized double-blinded placebo controlled trial. Clin. Infect. Dis. 2021. [CrossRef]

330. Libraty, D.H.; Young, P.R.; Pickering, D.; Endy, T.P.; Kalayanarooj, S.; Green, S.; Vaughn, D.W.; Nisalak, A.; Ennis, F.A.; Rothman, A.L. High circulating levels of the dengue virus nonstructural protein NS1 early in dengue illness correlate with the development of dengue hemorrhagic fever. J. Infect. Dis. 2002, 186, 1165-1168. [CrossRef] [PubMed]

331. Yang, Y.; Meng, Y.L.; Duan, S.M.; Zhan, S.B.; Guan, R.L.; Yue, T.F.; Kong, L.H.; Zhou, L.; Deng, L.H.; Huang, C.; et al. REBACIN ${ }^{\circledR}$ as a noninvasive clinical intervention for high-risk human papillomavirus persistent infection. Int. J. Cancer 2019, 145, $2712-2719$. [CrossRef] [PubMed]

332. Yang, Y.; Hu, T.; Ming, X.; Yang, E.; Min, W.; Li, Z. REBACIN ${ }^{\circledR}$ is an optional intervention for persistent high-risk human papillomavirus infection: A retrospective analysis of 364 patients. Int. J. Gynaecol. Obstet. 2021, 152, 82-87. [CrossRef]

333. Yuen, M.F.; Gane, E.J.; Kim, D.J.; Weilert, F.; Yuen Chan, H.L.; Lalezari, J.; Hwang, S.G.; Nguyen, T.; Flores, O.; Hartman, G.; et al. Antiviral Activity, Safety, and Pharmacokinetics of Capsid Assembly Modulator NVR 3-778 in Patients with Chronic HBV Infection. Gastroenterology 2019, 156, 1392-1403. [CrossRef]

334. Zhang, H.; Wang, F.; Zhu, X.; Chen, Y.; Chen, H.; Li, X.; Wu, M.; Li, C.; Liu, J.; Zhang, Y.; et al. Antiviral Activity and Pharmacokinetics of the HBV Capsid Assembly Modulator GLS4 in Patients with Chronic HBV Infection. Clin. Infect. Dis. 2020. [CrossRef] [PubMed]

335. Chaccour, C.; Casellas, A.; Blanco-Di Matteo, A.; Pineda, I.; Fernandez-Montero, A.; Ruiz-Castillo, P.; Richardson, M.A.; Rodríguez-Mateos, M.; Jordán-Iborra, C.; Brew, J.; et al. The effect of early treatment with ivermectin on viral load, symptoms and humoral response in patients with non-severe COVID-19: A pilot, double-blind, placebo-controlled, randomized clinical trial. EClinicalMedicine 2021, 32, 100720. [CrossRef] [PubMed]

336. Mohamed, M.S.; Kobayashi, A.; Taoka, A.; Watanabe-Nakayama, T.; Kikuchi, Y.; Hazawa, M.; Minamoto, T.; Fukumori, Y.; Kodera, N.; Uchihashi, T.; et al. High-speed atomic force microscopy reveals loss of nuclear pore resilience as a dying code in colorectal cancer cells. ACS Nano 2017, 11, 5567-5578. [CrossRef] [PubMed]

337. Nishide, G.; Lim, K.; Mohamed, M.S.; Kobayashi, A.; Hazawa, M.; Watanabe-Nakayama, T.; Kodera, N.; Ando, T.; Wong, R.W. High-speed atomic force microscopy reveals spatiotemporal dynamics of histone protein $\mathrm{H} 2 \mathrm{~A}$ involution by DNA inchworming J. Phys. Chem. Lett. 2021, 12, 3837-3846. [CrossRef] [PubMed] 
338. Lim, K.; Kodera, N.; Wang, H.; Mohamed, M.S.; Hazawa, M.; Kobayashi, A.; Yoshida, T.; Hanayama, R.; Yano, S.; Ando, T.; et al. High-Speed AFM reveals molecular dynamics of human influenza A hemagglutinin and its interaction with exosomes. Nano Lett. 2020, 20, 6320-6328. [CrossRef]

339. Lim, K.S.; Mohamed, M.S.; Wang, H.; Hazawa, M.; Kobayashi, A.; Voon, D.C.; Kodera, N.; Ando, T.; Wong, R.W. Direct visualization of avian influenza H5N1 hemagglutinin precursor and its conformational change by high-speed atomic force microscopy. Biochim. Biophys. Acta. Gen. Subj. 2020, 1864, 129313. [CrossRef] [PubMed] 